\title{
Evaluating the Polishing of Skid Aggregates in Asphalt using the British Pendulum Tester
}

\author{
Allison Nicole Givens \\ West Virginia University, angivens@mix.wvu.edu
}

Follow this and additional works at: https://researchrepository.wvu.edu/etd

Part of the Civil Engineering Commons, and the Transportation Engineering Commons

\section{Recommended Citation}

Givens, Allison Nicole, "Evaluating the Polishing of Skid Aggregates in Asphalt using the British Pendulum Tester" (2020). Graduate Theses, Dissertations, and Problem Reports. 7531.

https://researchrepository.wvu.edu/etd/7531

This Thesis is protected by copyright and/or related rights. It has been brought to you by the The Research Repository @ WVU with permission from the rights-holder(s). You are free to use this Thesis in any way that is permitted by the copyright and related rights legislation that applies to your use. For other uses you must obtain permission from the rights-holder(s) directly, unless additional rights are indicated by a Creative Commons license in the record and/ or on the work itself. This Thesis has been accepted for inclusion in WVU Graduate Theses, Dissertations, and Problem Reports collection by an authorized administrator of The Research Repository @ WVU. For more information, please contact researchrepository@mail.wvu.edu. 
Evaluating the Polishing of Skid Aggregates in Asphalt using the British Pendulum Tester

\title{
Allison Givens
}

Thesis submitted

to the Benjamin Statler College of Engineering and Mineral Resources at West Virginia University

in partial fulfillment of the requirements for the degree of

Master of Science in

Civil and Environmental Engineering

\author{
John P. Zaniewski, Ph.D., P.E., Chair \\ John Quaranta, Ph.D., P.E. \\ Karl Barth, Ph.D.
}

Wadsworth Department of Civil and Environmental Engineering

Morgantown, West Virginia

2020

Keywords: British Pendulum Tester, Polishing, Skid Resistant Aggregates

Copyright 2020 Allison Givens 


\begin{abstract}
Evaluating the Polishing of Skid Aggregates in Asphalt using the British Pendulum Tester
\end{abstract}

\title{
Allison Givens
}

To ensure the pavements in West Virginia have adequate skid resistance the Division of Highways evaluates and approves skid resistant aggregate sources for all wearing courses on roads with an ADT of 3,000 or greater. Unfortunately, the supply of skid aggregates in West Virginia is depleting quickly. To find a potential alternative to using skid resistant aggregates, laboratory polishing of asphalt samples was performed using a Circular Track Polishing Machine, and friction was tested using a British Pendulum Tester. The experiment was designed to investigate how a specific aggregate type provides skid resistance to a hot asphalt mixture.

The objective of this research was to evaluate the repeatability of a newly developed polishing procedure, establish a difference between skid and non-skid mixes, and investigate the effect of the amount of skid resistant aggregate on the friction an asphalt mixture. Four mixes with varying amounts of skid aggregate were evaluated. The four mixes were compacted, polished, and tested following a recommended protocol established in an earlier phase of the research. The procedure was then used to determine the friction values of the mixes. Insoluble residue tests were then performed on the skid specific mixes to verify the skid resistant aggregate contents. 


\section{ACKNOWLEDGMENTS}

I would like to thank my advisor, Dr. John Zaniewski, for providing with the opportunity to further my education and for his utmost guidance and assistance in completing this research. I would also like to thank my committee members, Dr. John Quaranta and Dr. Karl Barth, for each of their contributions and support throughout this research.

I would also like to thank the West Virginia Division of Highways (WVDOH) for providing this opportunity and the resources necessary to complete it. I would like to thank participating contractors for providing materials needed to for this research. I am extremely grateful to Chadley Miller for the tremendous amount of help in developing and performing this experiment.

Next, I want to thank my fellow graduate students for all of their support and assistance throughout my research. Lastly, I want to thank my family and friends for their endless support throughout my graduate education and this project. 


\section{Table of Contents}

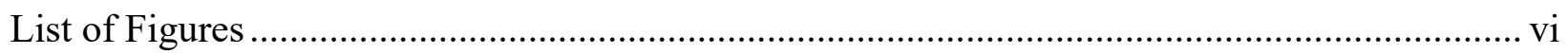

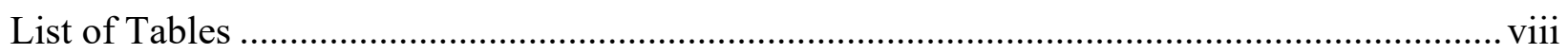

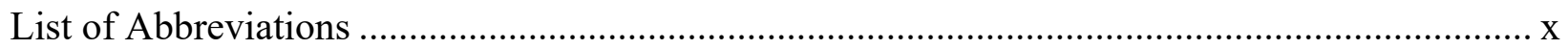

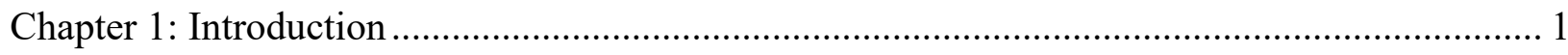

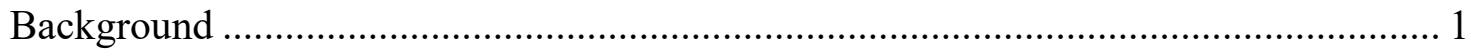

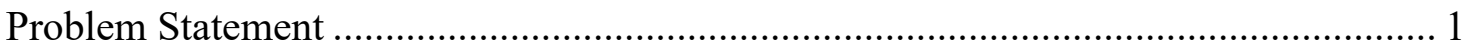

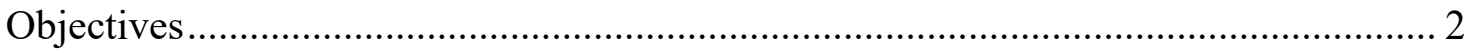

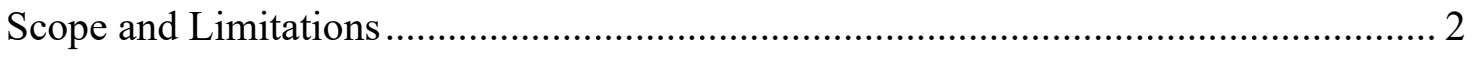

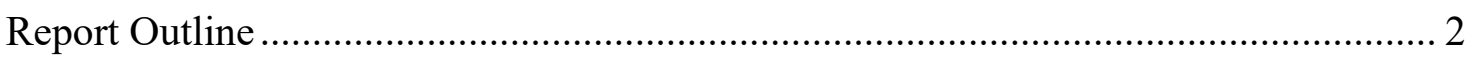

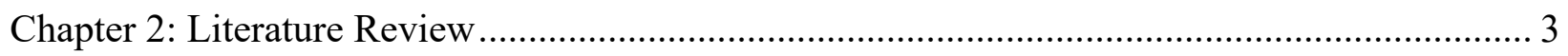

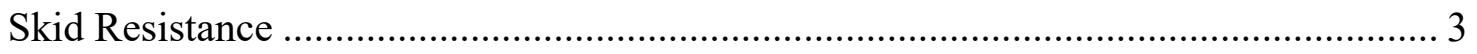

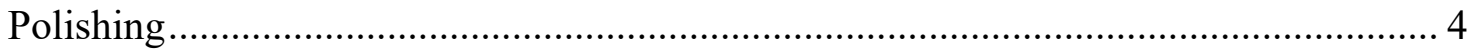

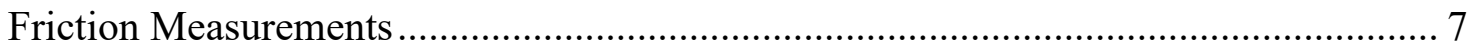

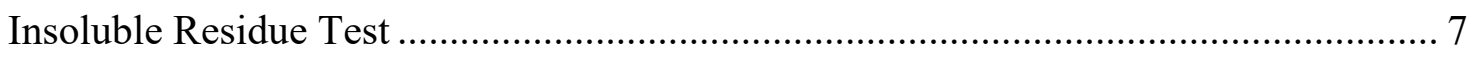

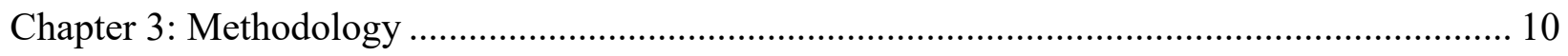

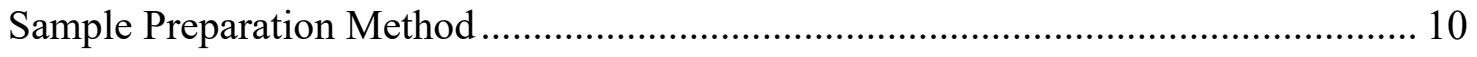

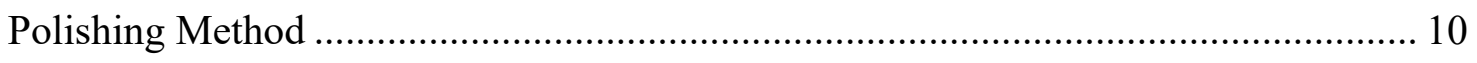

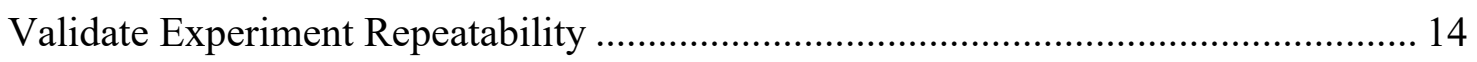

Skid Resistant Asphalt Experiment ......................................................................... 15

Insoluble Residue Test ...................................................................................... 16

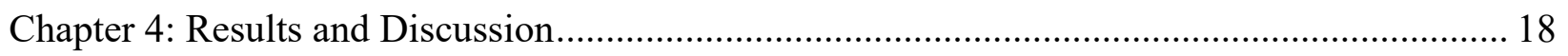

Comparison for Repeatability ………………………......................................... 18

Skid Resistant Asphalt Results............................................................................... 21

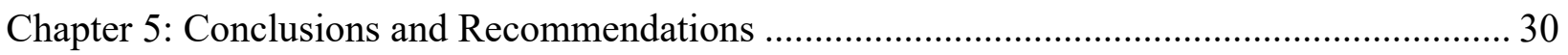


Conclusions

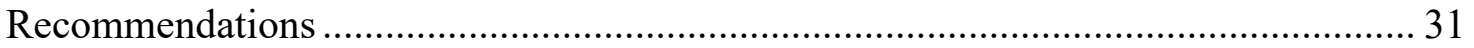

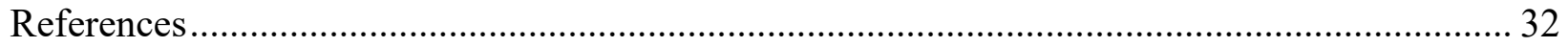

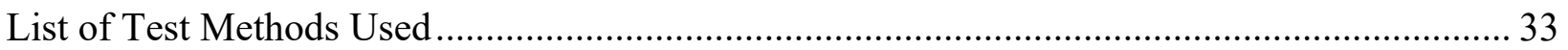

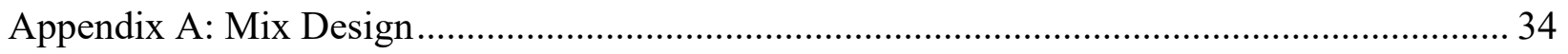

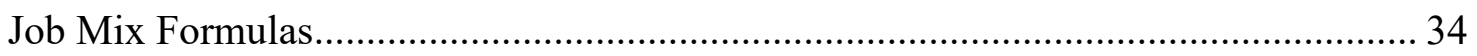

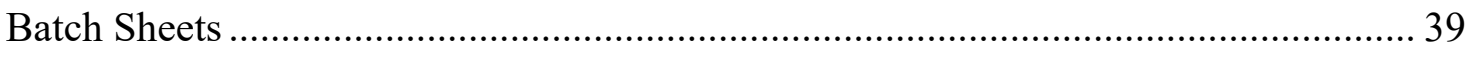

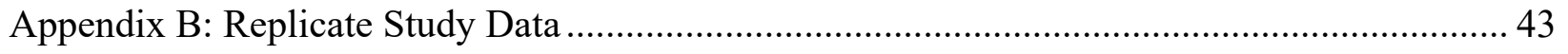

Appendix C: Skid Resistant Asphalt Experiment Data ………………..................................... 54

Appendix D: Insoluble Residue Data …………...................................................................... 59

Asphalt Burn-off …………………………………........................................... 59

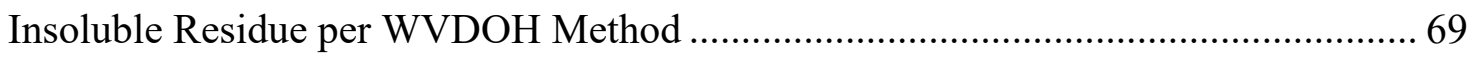

Insoluble Residue per Material Passing WVDOH Method ........................................... 72

Insoluble Residue per Total Blend of Sample............................................................ 75 


\section{List of Figures}

Figure 1. Illustration of Aggregate Microtexture and Macrotexture (Mataei et al., 2016) ........... 4

Figure 2. North Carolina State University Circular Track Polishing Machine (ASTM E660) ..... 5

Figure 3: British Pendulum Tester................................................................................. 12

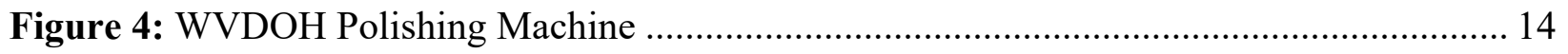

Figure 5: Comparison Chart for Estimation of Percentage Composition (WVDOH MP

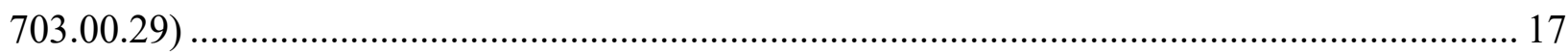

Figure 6: Average BPN After 48,000 Wheel Passes at 4\% VTM with High Toe ..................... 18

Figure 7: Average BPN After 48,000 Wheel Passes at 8\% VTM with High Toe..................... 19

Figure 8: Average BPN After 48,000 Wheel Passes at 4\% VTM with Low Toe...................... 19

Figure 9: Average BPN After 48,000 Wheel Passes at 8\% VTM with Low Toe...................... 20

Figure 10: Average BPN Comparison for Original vs. Replicate ...................................... 21

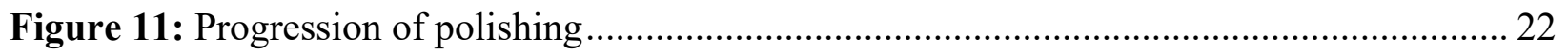

Figure 12: Average BPN Numbers for $9.5 \mathrm{~mm}$ SKID Study at 7\% VTM with High Toe......... 23

Figure 13: Average BPN Numbers for $9.5 \mathrm{~mm}$ SKID Study at 7\% VTM with Low Toe.......... 23

Figure 14: Average BPN per specimen for Low Toe and High Toe after 80,000 Wheel Passes 24

Figure 15: Skid Aggregate Content vs. Average BPN ..................................................... 26

Figure 16: Skid Aggregate Content vs. +200 Quartz Insoluble Residue................................ 27

Figure 17: Microscopic view of Insoluble Residue ............................................................ 29

Figure 18: Job Mix Formula for J. F. Allen Co. - 12.5 mm SKID - RAP ............................. 34

Figure 19: Job Mix Formula for West Virginia Paving, Inc. - Wearing 1 - RAP ................... 35

Figure 20: Job Mix Formula for Greer - Wearing 1 Heavy .............................................. 36

Figure 21: Job Mix Formula for West Virginia Paving, Inc. - 12.5 mm Skid - RAP .............. 37

Figure 22: Job Mix Formula for J. F. Allen Co. - 9.5 mm SKID - Per Design Mixture............ 38

Figure 23: Batch Sheet for J. F. Allen Co. - 9.5 mm SKID - No Skid Mixture........................ 39

Figure 24: Batch Sheet for J. F. Allen Co. - 9.5 mm SKID - Per Design Mixture .................. 40

Figure 25: Batch Sheet for J. F. Allen Co. - 9.5 mm SKID - Opposite Skid Mixture ............. 41

Figure 26: Batch Sheet for J. F. Allen Co. - 9.5 mm SKID - All Skid Mixture ...................... 42

Figure 27: Binder Burn-off Tickets for All Skid and Opposite Skid...................................... 59

Figure 28: Binder burn-off tickets for Per Design and No Skid .......................................... 60

Figure 29: Gradation of Aggregates from binder burn-off for All Skid Sample \#1 .................. 61 
Figure 30: Gradation of Aggregates from binder burn-off for All Skid Sample \#2 .................. 62

Figure 31: Gradation of Aggregates from binder burn-off for Opposite Skid Sample \#1 .......... 63

Figure 32: Gradation of Aggregates from binder burn-off for Opposite Skid Sample \#2 .......... 64

Figure 33: Gradation of Aggregates from binder burn-off for Per Design Sample \#1 ............... 65

Figure 34: Gradation of Aggregates from binder burn-off for Per Design Sample \#2 ............... 66

Figure 35: Gradation of Aggregates from binder burn-off for No Skid Sample \#1 ................. 67

Figure 36: Gradation of Aggregates from binder burn-off for No Skid Sample \#2 „................. 68 


\section{List of Tables}

Table 1: Specification of Components in CTPM according to ASTM E660 ........................... 6

Table 2: Modifications of WVDOH Polishing Equipment and Procedure to ASTM E660 (Hoyer,

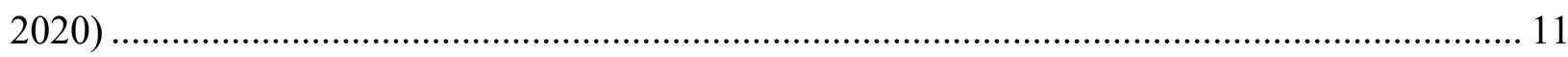

Table 3: Combinations of mixtures used in testing........................................................ 15

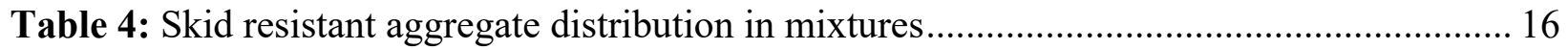

Table 5: Statistical comparison for original vs. replicate results ........................................... 20

Table 6: BPN Average and Standard Deviation ................................................................ 25

Table 7: t-Test results for average BPN of specimen at 80,000 wheel passes.......................... 26

Table 8: Summary of average Insoluble Residue results per sample for each method ............. 27

Table 9: Insoluble Residue (\% Quartz) vs. Average BPN ..................................................... 28

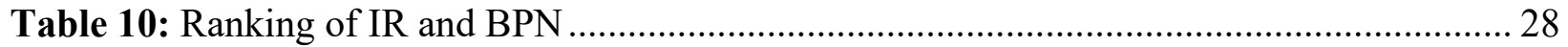

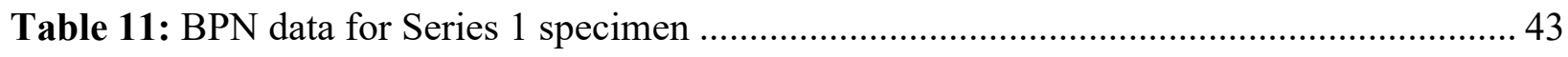

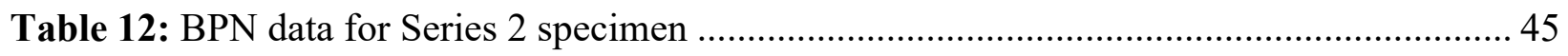

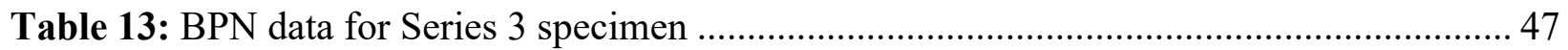

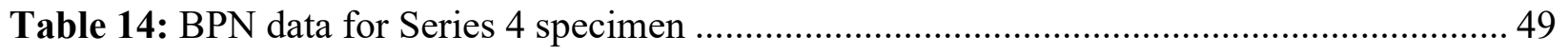

Table 15: Data for Original and Replicate Statistical Comparison....................................... 51

Table 16: Comparison of Average BPN After 48,000 Wheel Passes at 4\% VTM, High Toe..... 52

Table 17: Comparison of Average BPN After 48,000 Wheel Passes at 8\% VTM, High Toe..... 52

Table 18: Comparison of Average BPN After 48,000 Wheel Passes at 4\% VTM, Low Toe ..... 53

Table 19: Comparison of Average BPN After 48,000 Wheel Passes at 8\% VTM, Low Toe ..... 53

Table 20: BPN data for specimen using High Toe .............................................................. 54

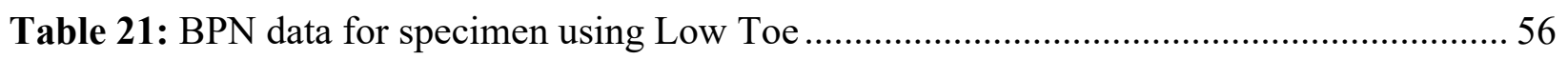

Table 22: Average BPN Numbers for $9.5 \mathrm{~mm}$ SKID Study at 7\% VTM with High Toe .......... 58

Table 23: Average BPN Numbers for $9.5 \mathrm{~mm}$ SKID Study at 7\% VTM with Low Toe ........... 58

Table 24: Skid Aggregate Content vs Average BPN ........................................................ 58

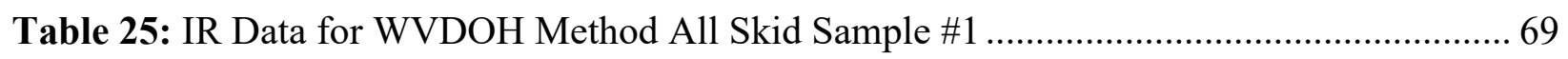

Table 26: IR Data for WVDOH Method All Skid Sample \#2 ............................................... 69

Table 27: IR Data for WVDOH Method Opposite Skid Sample \#1 _....................................... 69

Table 28: IR Data for WVDOH Method Opposite Skid Sample \#2 ....................................... 70 
Table 29: IR Data for WVDOH Method Per Design Sample \#1 ……......................................... 70

Table 30: IR Data for WVDOH Method Per Design Sample \#2 ……….................................. 70

Table 31: IR Data for WVDOH Method No Skid Sample \#1 ...................................................... 71

Table 32: IR Data for WVDOH Method No Skid Sample \#2 ……………………………....... 71

Table 33: IR Data for Material Passing WVDOH Method All Skid Sample \#1 ……………...... 72

Table 34: IR Data for Material Passing WVDOH Method All Skid Sample \#2 ……….............. 72

Table 35: IR Data for Material Passing WVDOH Method Opposite Skid Sample \#1 ................ 72

Table 36: IR Data for Material Passing WVDOH Method Opposite Skid Sample \#2 ………..... 73

Table 37: IR Data for Material Passing WVDOH Method Per Design Sample \#1 ...................... 73

Table 38: IR Data for Material Passing WVDOH Method Per Design Sample \#2 ..................... 73

Table 39: IR Data for Material Passing WVDOH Method No Skid Sample \#1 .......................... 74

Table 40: IR Data for Material Passing WVDOH Method No Skid Sample \#2 .......................... 74

Table 41: IR Data for Total Blend All Skid Sample \#1 ……………………………............... 75

Table 42: IR Data for Total Blend All Skid Sample \#2 …………………………………...... 75

Table 43: IR Data for Total Blend Opposite Skid Sample \#1 ………………………………... 75

Table 44: IR Data for Total Blend Opposite Skid Sample \#2 ……………………................... 76

Table 45: IR Data for Total Blend Per Design Sample \#1 ……………...................................... 76

Table 46: IR Data for Total Blend Per Design Sample \#2 …………………………................... 76

Table 47: IR Data for Total Blend No Skid Sample \#1 …………………………...................... 77

Table 48: IR Data for Total Blend No Skid Sample \#2 ……………………………….............. 77 


\section{List of Abbreviations}

AASHTO = American Association of State Highway and Transportation Officials

ASTM $=$ American Society for Testing and Materials

$\mathrm{BPN}=$ British Pendulum Number

$\mathrm{BPT}=$ British Pendulum Tester

$\mathrm{CTPM}=$ Circular Track Polishing Machine

FHWA $=$ Federal Highway Administration

$\mathrm{G}_{\mathrm{mb}}=$ Bulk Specific Gravity

$\mathrm{G}_{\mathrm{mm}}=$ Specific Gravity of Mix

HMA = Hot Mix Asphalt

$\mathrm{IR}=$ Insoluble Residue

$\mathrm{JFA}=\mathrm{J} . \mathrm{F}$. Allen Company

$\mathrm{NCSU}=$ North Carolina State University

RAP $=$ Reclaimed Asphalt Pavement

SGC $=$ Superpave Gyratory Compactor

$\mathrm{SR}=$ Skid-RAP Asphalt Mixture

VTM $=$ Voids in the Total Mixture

W1 = Wearing 1 Asphalt Mixture Course

$\mathrm{WV}=$ West Virginia

WVDOH $=$ West Virginia Division of Highways

WVP $=$ West Virginia Paving, Inc.

WVU $=$ West Virginia University 


\section{Chapter 1: Introduction}

\section{Background}

Safety characteristics for a roadway are of the highest priority when designing a roadway. On average, there are about 5,891,000 car crashes each year, and 21\% of these crashes are weather related (FHWA, 2020). Weather events can greatly affect the roadways, and safety is one of those factors. Skid resistance is a large contributor to safety of the roadways. Skid resistance can be achieved in many ways; a couple ways include: microsurfacing treatments or proper surface mix designs with specific aggregate characteristics. Polish resistant aggregates, or skid resistant aggregates, are a large contender in skid resistance mix designs (FHWA, 2005).

The polish resistant aggregates are used in the surface courses to increase the skid resistance by reducing the polishing effect from vehicles. Skid resistant aggregates utilized in hot mix asphalt (HMA) mixtures is in great demand, but the supply of the skid resistant aggregates is low. Doing research on the effects of polishing skid resistant aggregates in a hot mix asphalt (HMA) pavements compared to the effects of polishing non-skid resistant aggregates in pavements will allow a better understanding of the surface characteristics of the respective asphalt pavements. The data found could provide insight on the characteristics the chosen aggregates provide to the asphalt pavement when designing new mixture designs.

\section{Problem Statement}

This research was completed to identify the skid resistance of asphalt mixes using the British Pendulum Tester (BPT). The research was performed to find a correlation between the amount of skid resistant aggregates used in the mixture to the amount of skid resistance of the asphalt pavement with the newly developed method by a previous experimenter and West Virginia University (WVU). These findings can provide insight for the WVDOH and contractors on the asphalt pavements' skid resistance performance. 


\section{Objectives}

There were three main objectives for this research: 1) evaluate test method repeatability, 2) polish and test the four mixes, and 3) verify the skid resistant aggregate content of each mixture design.

Achieving these objectives ensures that the procedure for finding the friction results can be used for future experiments. The verified data could provide insight to alternative mix deigns that provide adequate skid resistance without the use of limited skid resistant aggregates.

\section{Scope and Limitations}

The polishing and friction measurement equipment used in this research were provided by the WVDOH. There was no opportunity to evaluate and select other equipment. The HMA for the replicate study were provided by three contractors. The experiment with the varying amounts of skid aggregate were from a single contractor. Field samples were not available for testing. All test were performed on laboratory compacted samples.

\section{Report Outline}

The report has five chapters. These chapters include: Introduction, literature review, methodology, results and discussion, and conclusion and recommendations. The first chapter is the introduction. The second chapter is the literature review. Chapter three covers the methodology throughout the project. Chapter four presents and discusses the results found during testing. The fifth chapter explains the conclusions and recommendations for future work. Appendices are provided for supplemental data. 


\section{Chapter 2: Literature Review}

Creating a device to accurately simulate the polishing effect in the field is vital to laboratory testing hot mix asphalt (HMA) polishing. Testing methods proceeding polishing includes a British Pendulum Tester (BPT), as described in AASHTO and ASTM standards. A Circular Track Polishing Machine CTPM and a British Pendulum Tester (BPT) were delivered to WVU to perform such tests. These two devices will allow for the evaluation of skid resistance performance of the HMA mixtures designed for this experiment. The following reviews:

- Summary of skid resistance in asphalt pavements

- Polishing HMA using an ASTM E660 device

- Friction measurements with the British Pendulum Tester

- Insoluble Residue Test

\section{Skid Resistance}

Skid resistance is an essential characteristic for roadways. Skid resistance serves as a safety measure when designing a pavement. Skid resistance is defined as the force between the tire and the roadway that prevents the tire from sliding. The skid resistance depends on the tire and pavement characteristics. The pavement characteristics affecting skid resistance are macrotexture and microtexture (Liang, 2003).

Macrotexture is the roughness that can be seen with the eye. The aggregate size and the voids between the aggregates are contributors to macrotexture. Macrotexture is described as voids ranging from $0.5 \mathrm{~mm}$ up to $50 \mathrm{~mm}$ (Henry, 2000). Macrotexture affects friction on wet pavement at higher speeds, where the voids are large enough to disperse water from the pavement surface (FHWA, 2015).

Microtexture can be described as the surface texture of the aggregates. Microtexture affects the skid resistance at lower speeds (Henry, 2000). Microtexture is described as variations in the surface texture in the range of $0.001 \mathrm{~mm}-0.5 \mathrm{~mm}$ (Henry, 2000). 
Figure 1 illustrates the difference between microtexture and macrotexture. Microtexture can be effected by the type of aggregates used in the asphalt mixture. When using an aggregates that is not easily polished, or skid resistant, it can increase the longevity of microtexture.

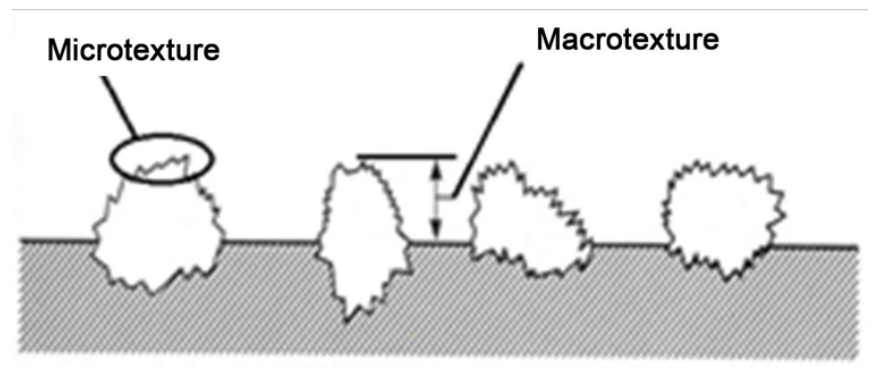

Figure 1. Illustration of Aggregate Microtexture and Macrotexture (Mataei et al., 2016)

Some aggregates that will increase the friction of the surface are sandstone, quartz, limestone, and granite. The WVDOH MP 402.02.20 describes how skid resistant aggregates are tested to be qualified skid aggregates for West Virginia. The percentage of carbonate particles is evaluated in order to determine the percentage of material that is not polish susceptible. The WVDOH MP 703.00.29 is an additional test performed to determine the amount of insoluble residue in the carbonate aggregates. The material studied in WVDOH MP 703.00.29 test is quartz, and the final percentage of insoluble residue is measured from the total amount of quartz passing through the No. 30 sieve and retained on the No. 200 sieve.

\section{Polishing}

The skid resistance of a pavement decreases due to the polishing from vehicle tires over a period of time or cycles. Polishing devices are used to simulate the friction low of pavement materials in the laboratory. There are many types polishing devices, however, the Circular Track Polishing Machine (CTPM) developed at North Carolina State University (NCSU), which was the basis for the CTPM described in ASTM E660, Figure 2, was selected by the WVDOH for use in this research. 


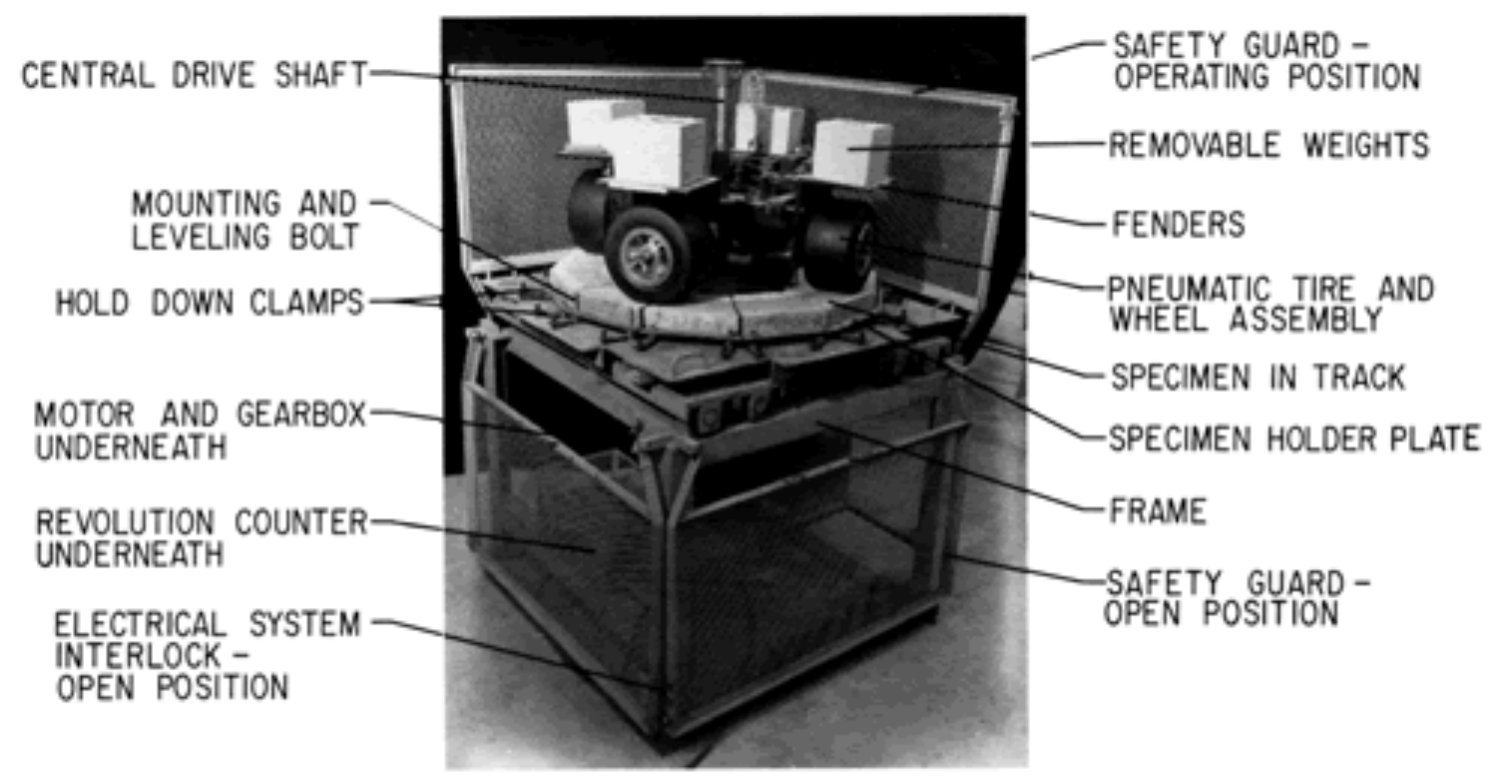

Figure 2. North Carolina State University Circular Track Polishing Machine (ASTM E660)

The main components of the CTPM are described in Table 1 (ASTM E660). The prescribed polishing and testing sequence is:

1. The initial friction is measured of twelve samples.

2. Place samples flush in the mounting plates or clamping ring.

3. Lower the wheels onto the samples

4. Run the polisher at $30 \mathrm{rpm}$ for the desired revolutions.

5. Stop polishing after 1 hour and measure the friction of each sample.

6. Repeat friction measurements in 2 hour intervals. The intervals are performed until the terminal polishing is achieved, at approximately 8 hours (ASTM E660). 
Table 1: Specification of Components in CTPM according to ASTM E660

\begin{tabular}{|c|c|c|}
\hline Component & Specification Elements & Purpose \\
\hline \multirow[t]{7}{*}{ Wheel Assembly } & Four equally spaced tires & \\
\hline & $\begin{array}{l}\text { Individually suspended from central drive } \\
\text { shaft }\end{array}$ & \\
\hline & Adjustable wheel toe & $\begin{array}{l}\text { Alternating toe-in } 4^{\circ} \text { and } \\
\text { toe-out } 2^{\circ}\end{array}$ \\
\hline & Free rolling wheel & \\
\hline & $\begin{array}{l}\text { Nylon smooth no-pattern tread tires, 2-ply } \\
\text { rating }\end{array}$ & \\
\hline & Tire size of $11 \mathrm{in} \times 6 \mathrm{in} \times 5 \mathrm{in}$, tire pressure $20 \mathrm{psi}$ & \\
\hline & Horizontal fender above each wheel & $\begin{array}{l}\text { Hold extra weight for } \\
\text { increased wheel loading }\end{array}$ \\
\hline \multirow[t]{2}{*}{ Drive Mechanism } & Electric motor & Rotate central drive shaft \\
\hline & Allowable $30 \pm 2 \mathrm{rpm}$ & \\
\hline \multirow[t]{2}{*}{ Circular Track } & 36 inch diameter, from center of wheel paths & \\
\hline & $\begin{array}{l}\text { Adequate spacing for } 12 \text { equally spaced } \\
\text { specimen holders }\end{array}$ & \\
\hline \multirow[t]{4}{*}{ Specimen Holder } & Bottom metal mounting plates & $\begin{array}{l}\text { Base for trapezoidal and } \\
\text { circular specimens }\end{array}$ \\
\hline & Three adjustable, lockable bolts & $\begin{array}{l}\text { Mounting and leveling } \\
\text { individual specimens on the } \\
\text { metal plates }\end{array}$ \\
\hline & $\begin{array}{l}\text { Top metal plate, with evenly spaced } 6 \text { inch } \\
\text { circular cutouts in wheel path }\end{array}$ & $\begin{array}{l}\text { Track running surface for } \\
\text { circular specimens }\end{array}$ \\
\hline & Clamping rings & $\begin{array}{l}\text { Securing sample when epoxy } \\
\text { glue is not used }\end{array}$ \\
\hline \multirow[t]{3}{*}{ Electrical System } & Comprised of three circuits & \\
\hline & Motor circuit with slow-blow fuse & Protect motor in accidents \\
\hline & Subtracting predetermined revolution counter & Control motor \\
\hline Safety Guards & Interlocked into motor circuit & $\begin{array}{l}\text { Machine will not operate if } \\
\text { safety guards are not in place }\end{array}$ \\
\hline
\end{tabular}




\section{Friction Measurements}

There are several methods for evaluating pavement texture and friction in a laboratory. The British Pendulum Tester (BPT) was selected by the WVDOH for use on this project. The BPT is a widely accepted device; its use is covered by ASTM E303 and AASHTO T 278. The BPT measures the friction as a rubber pad slides across the sample surface. Since the pendulum moves at a speed equivalent to $10 \mathrm{~km} / \mathrm{h}$ or $6 \mathrm{mph}$ (Henry, 2000), the friction is a measure of microtexture (AASHTO T 278).

The BPT has to be set up according to specifications when testing a specimen. The base of the BPT has 3 adjustable legs that are to be used for leveling the machine before testing. The pendulum has to be raised or lowered to the height for the rubber slider to have a contact path of $415 / 16 \pm 1 / 16 \mathrm{in}$. on the specimen. Once this is achieved, the surface of the specimen being tested must be thoroughly cleaned, and the surface must be sufficiently wetted (ASTM E303). The specimen is to be wetted, or spray with water, in order to mimic environmental conditions. Skid resistance is lower when the surface is wet than when the pavement is dry (Ahmad, 2015).

At the start of the test, the pendulum is locked in position and then released, allowing for the rubber slider to drag across the wetted surface. A drag pointer, connected to the pendulum, indicates the highest point the pendulum reaches. The BPT quantifies the friction value as the British Pendulum Number (BPN). The BPN ranges from 0 to 140, 0 equaling no friction. The $\mathrm{BPN}$ is a measure of the amount of energy lost when the slider is propelled over the sample $(\mathrm{Lu}$, 2006). This procedure is performed 5 times for specimens with flat surfaces. The results of the first swing is not recorded; the average of the results for the remaining 4 swings is the BPN.

\section{Insoluble Residue Test}

The skid resistance of the pavements also depends on the amount of insoluble residue in the aggregates being used (O'Brien and Haddock, 2009). "In the insoluble residue test (ASTM D3042), the aggregate is dissolved in dilute hydrochloric acid, and the remaining insoluble portion is usually made up of quartz (silica), feldspar (clays), or other insoluble minerals" (O'Brien and Haddock, 2009). The purpose of this test is to identify the properties of the aggregates by removing the carbonate material with hydrochloric acid and relate the properties, such as hardness, to the skid resistance. Many state DOTs have a modified version of the 
insoluble residue test (Jayawickrama et al. 1998). The insoluble residue test is used in West Virginia to determine the amount of aggregate that is not able to be polished easily and allow for greater skid resistance, such as quartz. The MP 402.02.20 test allows for WVDOH to determine if the aggregate type in questioning is considered as a skid resistant aggregate. The MP 703.00.29 allows for the WVDOH to determine the amount of insoluble material, specifically quartz, left from the blend of carbonate aggregates.

The type of aggregate chosen for the mix design is crucial for the frictional properties. As mentioned previously, the texture of the pavements greatly affects the skid resistance. The texture includes the microtexture and macrotexture, with microtexture being considered more influential to skid resistance. When the pavement is polished by vehicle tires, there is a decrease the skid resistance (O'Brien and Haddock, 2009). Since the skid resistance is measured by the force between tire and the pavement, when there is water on the road, this can disrupt the friction force between the two surfaces. This is especially worse for pavements that are polished; the pavement has no microtexture to remove the thin water film left from the larger movement of water due to macrotexture (O’Brien and Haddock, 2009). Choosing aggregates for the mix design that have a specific hardness is very important when trying to maintain adequate microtexture. Aggregates with a higher hardness have a "longer rate of polishing" which increases the lifespan of available microtexture (O'Brien and Haddock, 2009). It is important to have the higher hardness aggregates complemented with the softer mineral to keep the minerals well bonded (Liang, 2003). This will produce a design that will resist polishing and wearing effectively. Dahir and Mullen (1971) concluded that having a mixture of harder and softer minerals in the aggregates produced higher skid resistance that mixes having aggregates with mostly harder minerals.

When using softer minerals such as limestone or dolomite in the blend of aggregates, it is important to determine the content of insoluble residue since the carbonate aggregate is easily polished (O'Brien and Haddock, 2009). The first reports of insoluble residue correlating to skid resistance recommended that of the aggregates retained on the No. 200 sieve, at least ten percent of the aggregate blends should consist of insoluble residue. There are other recommendations of having insoluble residue contents of fifteen and twenty percent, but there is no evidence on which percentage performs best (O’Brien and Haddock, 2009). Additional studies recommend having at least 25 percent of insoluble residue of the total blend to maintain skid resistance 
(Masad et al. 2009). Others have reported of having 50 to 70 percent of the harder materials in the skid aggregates themselves to be sufficient (Dahir and Mullen, 1971).

The size of the skid resistant particle is also an important characteristic. While the first reports of insoluble residue include the materials retained on a No. 200 sieve, a study by Masad et al. (2009) suggests limiting the particle size to being retained on a No. 50 sieve for being counted in the contributing skid resistance. O'Brien and Haddock (2009) studied that having insoluble residue passing the No. 200 sieve increased skid resistance, speculating "that the tiny clay particles that make up the portion smaller than the \#200 sieve break out of the carbonate matrix creating an irregular surface and providing the needed micro-texture for good skid resistance." Other studies have shown that having insoluble residue sand increases the skid resistance (Dahir and Mullen, 1971). 


\section{Chapter 3: Methodology}

The research methodology included five steps: sample preparation, polishing methodology, replicate experiment, skid resistant mixes experiment, and evaluation of insoluble residue test of skid resistant mixes.

\section{Sample Preparation Method}

Sample preparation began with determining the maximum specific gravity $\left(\mathrm{G}_{\mathrm{mm}}\right)$ of the asphalt mixtures. Following AASHTO T 209, $1500 \mathrm{~g}$ of each asphalt mixture was heated in the oven in separate pans at $105^{\circ} \mathrm{C}$. The HMA Particles are separated by hand and left to cool to room temperature. The separated particles were placed into the pre-weighed vacuum container to determine the mass of the sample being used and perform mechanical agitation of the sample. The remaining weights were taken, and the $\mathrm{G}_{\mathrm{mm}}$ was calculated.

The mass of the mixture needed for each sample was then determined and samples were compacted accordingly to AASHTO R 83-17. Specimen with dimensions of $90 \mathrm{~mm}$ tall and 150 mm diameter were compacted with the Superpave Gyratory Compactor (SGC). To conserve the amount of asphalt mixture used and to fit the samples into the polishing machine, the height of $90 \mathrm{~mm}$ was preferred over the height in AASHTO R 83-17. Asphalt mixture was heated to $100^{\circ} \mathrm{C}$, quartered, and then heated to the mixture compaction temperature. The mixture is then placed into the compaction mold, compacted, and then left to cool to room temperature overnight. The sample is numbered, and the top and bottom are labeled.

The voids in the total mix (VTM) or air voids, is measured to verify the desired VTM for the experiment. This is done accordingly to Method A in AASHTO T 166-16. To prepare the specimen for this test, it is placed into the CoreDry device to remove any moisture inside the sample voids. The bulk specific gravity $\left(\mathrm{G}_{\mathrm{mb}}\right)$ is found, and the VTM is calculated. The specimen is ready for polishing once the desired VTM is verified.

\section{Polishing Method}

The WVDOH-CTPM developed by the following ASTM E660 is shown in Figure 4. There were minor modifications in the polishing machine developed by the WVDOH and the 
procedure recommended by Hoyer (2020). The differences from the ASTM E660 specifications are listed in Table 2.

Table 2: Modifications of WVDOH Polishing Equipment and Procedure to ASTM E660 (Hoyer, 2020)

\begin{tabular}{|c|c|c|c|}
\hline & & ASTM E660-90 & WVDOH \\
\hline \multirow{3}{*}{ Equipment } & \multirow[b]{2}{*}{ Tires } & Pressure $=20 \mathrm{psi}$ & Pressure $=30 \mathrm{psi}$ \\
\hline & & $\begin{array}{l}\text { Nylon smooth no- pattern; 2- } \\
\text { ply rating }\end{array}$ & Hoosier R80 \\
\hline & Wheels & Option for studded wheels & No studded wheels \\
\hline & Specimens & $\begin{array}{l}\text { Laboratory }=6 \text { " diameter, no } \\
\text { height specified; field core = } \\
\text { 6" diameter, 38mm height } \\
\text { (bituminous) }\end{array}$ & $\begin{array}{l}\text { Laboratory }=6 " \text { diameter, } \\
90 \mathrm{~mm} \text { height; } 6 " \text { diameter } \\
\text { field core specimens } \approx 90 \mathrm{~mm} \\
\text { height if possible (bituminous) }\end{array}$ \\
\hline & & $\begin{array}{l}\text { Option for concrete } \\
\text { specimens }\end{array}$ & No concrete specimens \\
\hline & Abrasive & No abrasive & Silicon Carbide Powder \\
\hline - & Toe Angles & $4^{\circ}$ toe in $2^{\circ}$ toe out only & $\begin{array}{l}4^{\circ} \text { toe in } 2^{\circ} \text { toe out; } \\
8^{\circ} \text { toe in } 4^{\circ} \text { toe out }\end{array}$ \\
\hline Procedure & Tire Hardness & No monitoring & $\begin{array}{l}\text { Monitored with durometer } \\
\text { every } 4,000 / 6,000 \text { revolutions } \\
(16,000 / 24,000 \text { wheel passes })\end{array}$ \\
\hline & & $\begin{array}{l}\text { NCSU Variable Speed } \\
\text { Friction Tester recommended }\end{array}$ & $\begin{array}{l}\text { British Pendulum Tester } \\
\text { (BPT) }\end{array}$ \\
\hline & Evaluation & $\begin{array}{l}\text { Measurements recorded at } 0 \text {, } \\
7200,14400,28000,43200, \\
\text { and 57,600 wheel passes }\end{array}$ & $\begin{array}{l}\text { Measurements recorded at } 0, \\
8000,16000,32000, \text { and } \\
48000 \text { wheel passes }\end{array}$ \\
\hline & $\begin{array}{l}\text { Sufficient } \\
\text { Polishing }\end{array}$ & $\begin{array}{l}57,600 \text { wheel passes }(7,200 \\
\text { wheel passes per hour for } 8 \mathrm{hr})\end{array}$ & 48,000 \\
\hline
\end{tabular}

Before polishing the initial friction if each sample was measured with the BPT, using the following steps:

1. Secure specimen in BPT fixing jig.

2. Adjust pendulum height for slider contact path of 5 inches. 
3. Lock pendulum in place.

4. With a spray bottle, do 30 sprays of water onto specimen surface.

5. Release pendulum.

6. Read BPN from the drag pointer.

7. Immediately, relock pendulum back into place.

8. Apply 5 sprays of water to the surface.

9. Release pendulum.

10. Read and record BPN from that drag pointer.

11. Repeat steps 7-10 a total of four times.

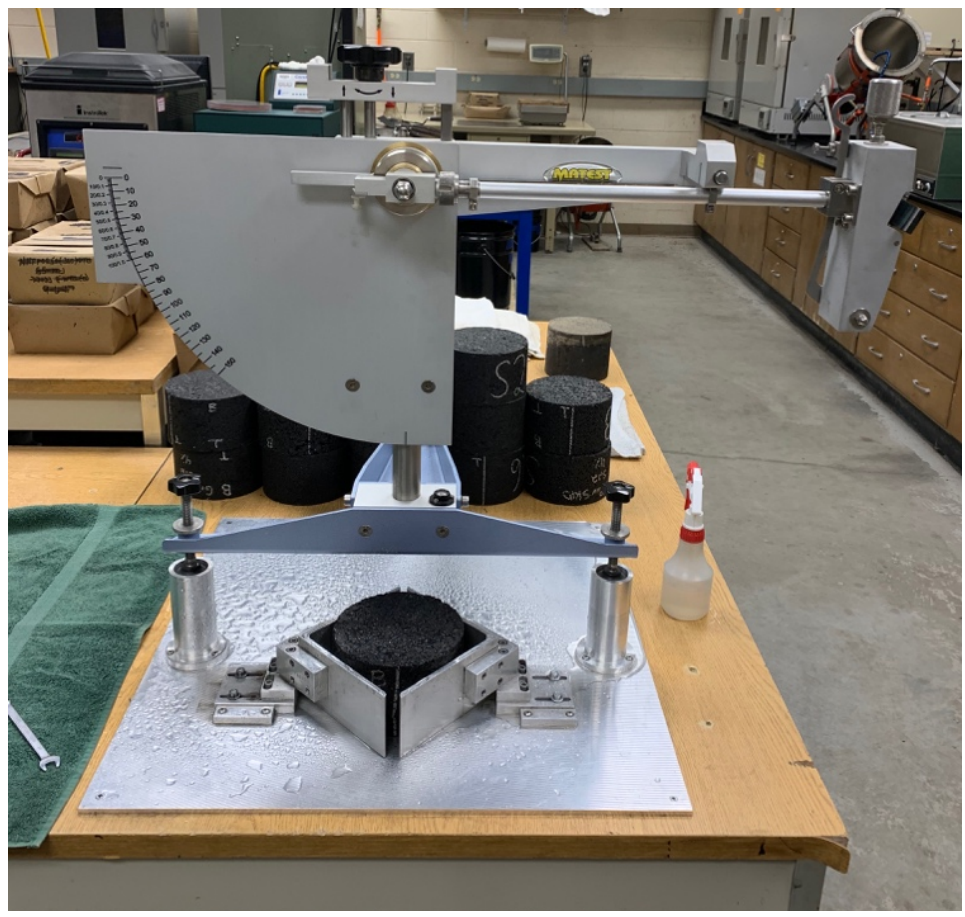

Figure 3: British Pendulum Tester

The specimen were air dried before placing them into the polishing machine. The steps for polishing were:

1. Place specimens into randomly selected housing component positions of the polisher.

2. Adjust housing component plate and bolt to raise or lower the specimen so it is level with the upper surface plate. 
3. The clamp is tightened around the sample to prevent rotation from the wheels.

4. Verify the tires are inflated to $30 \mathrm{psi}$

5. Measure the hardness of the tire using a Durometer; the tire hardness was measured every 4000 cycles.

6. The temperature of each specimen surface, the tire tread, and tire sidewall is to be taken with an infrared thermometer.

7. 2 grams of Silicon Carbide abrasive powder is distributed on the surface of each specimen.

8. The wheel assembly is lowered.

9. Weights totaling 50 pounds are placed and secured on the wheel assembly fender.

10. The safety guards are placed in the upright position.

11. The breaker box for the machine is switched on.

12. If on initial cycles, the revolution cycle counter is reset to 0 .

13. The variable frequency drive is placed to 0 and switched on.

14. The variable frequency drive is slowly increased to reach the $30 \mathrm{rev} / \mathrm{min}$ speed.

15. When desired number of revolutions is met, the polisher is stopped with the shut off button.

16. The safety guards are taken down.

17. The temperature of each specimen surface, tire tread, and tire sidewall is taken with an infrared thermometer.

18. The weights are taken off of the fenders.

19. The wheel assembly is lifted and locked into place.

20. The abrasive powder is cleaned off of specimen surfaces.

21. The clamps are loosened.

22. The samples are removed. 
This procedure is performed for all polishing cycles during the experiment. The BPN is measured for each sample after each polishing cycle. The cumulative number of cycles between friction measurements were $2000,4000,8000$, and 12,000 cycles. Since the polishing machine has four wheels, each revolution produces four wheel passes.

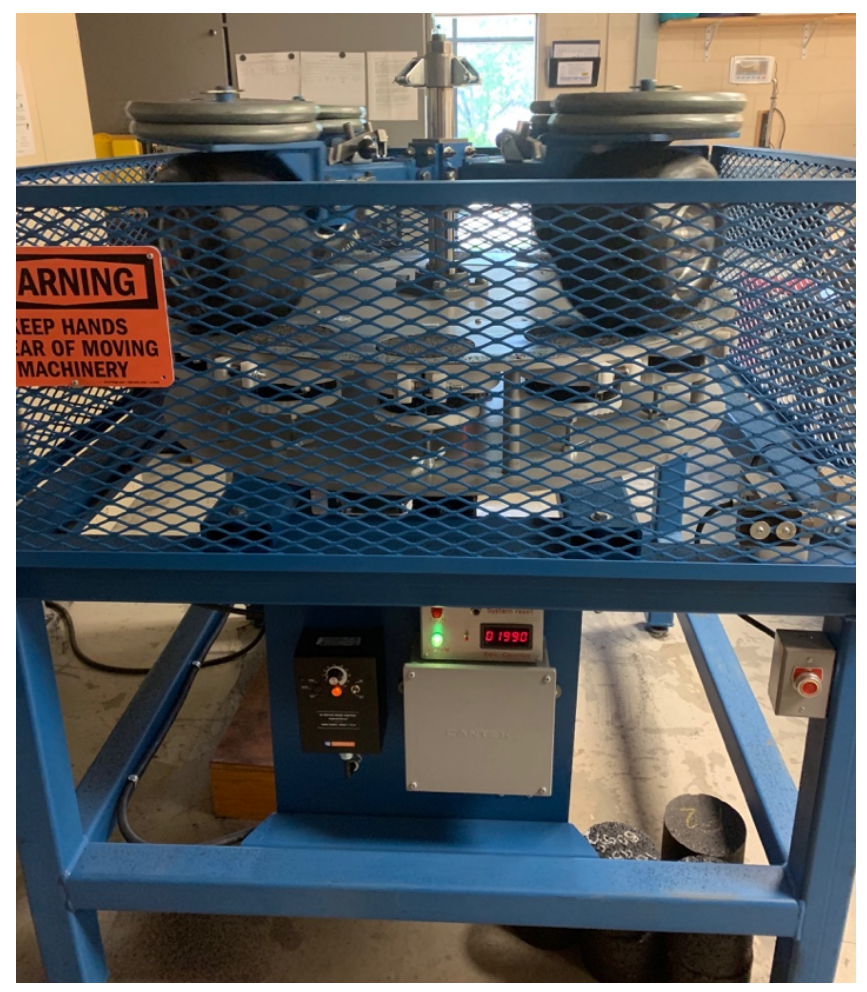

Figure 4: WVDOH Polishing Machine

\section{Validate Experiment Repeatability}

The polishing equipment and procedures are new developments that were only used by one researcher. Before this process can be implemented for making decisions about the skid resistance or friction of asphalt concrete it is important to verify the process is repeatable. The four asphalt mixes used by Hoyer (2020) were tested. The job mix formulas for these mixtures are in Appendix A. The four mixes are:

- J. F. Allen Co. - 12.5 mm Skid w/RAP (Mix 1)

- West Virginia Paving, Inc. - Wearing 1 w/RAP (Mix 2)

- Greer - Wearing 1 Heavy (Mix 3)

- West Virginia Paving, Inc. - 12.5 mm Skid w/RAP (Mix 4) 
To duplicate Hoyer's experiment, two toe settings and two air voids for the samples were tested:

- $\quad$ Toe levels - Low at $2^{\circ}$ and $4^{\circ}$, and High at $4^{\circ}$ and $8^{\circ}$

- $\mathrm{VTM}-4 \pm 0.5 \%$ and $8 \pm 0.5 \%$

In addition the tops and the bottoms of the samples were polished and tested, using the combinations described in Table 3.

Table 3: Combinations of mixtures used in testing

\begin{tabular}{|c|c|c|c|}
\hline Series & Mixture Types & Specimen Side & Toe Angles \\
\hline 1 & JFA 12.5mm Skid-RAP and WVP W1-RAP & Top & High Toe \\
\hline 2 & JFA 12.5mm Skid-RAP and WVP W1-RAP & Bottom & Low Toe \\
\hline 3 & Greer W1H and WVP 12.5mm Skid-RAP & Bottom & Low Toe \\
\hline 4 & Greer W1H and WVP 12.5mm Skid-RAP & Top & High Toe \\
\hline
\end{tabular}

The results were statistically compared to Hoyer's results. Measurements are provided in Appendix B.

\section{Skid Resistant Asphalt Experiment}

A skid resistant experiment was developed by contractor J. F. Allen Co. Starting with an approved skid mix, three variations were made as described in Table 4. The aggregate characteristics are described in Appendix A.

Three specimens of each mixture were compacted and verified to the desired VTM of $7 \pm$ $0.5 \%$. A VTM of $7 \%$ closely resembles field air voids in the field. A total of twelve samples were compacted for this experiment. The top and bottoms of the samples were tested using high and low toe angles, respectively. The polishing process was augmented with an additional 8,000 revolutions to ensure the minimum friction level reached. Measurement are provided in Appendix C. 
Table 4: Skid resistant aggregate distribution in mixtures

\begin{tabular}{|c|c|c|c|c|c|}
\hline & & \multicolumn{4}{|c|}{ Aggregate Composition* } \\
\hline Mixture Type & Percent Skid & 8 's $(40 \%)$ & $9 ' s(10 \%)$ & Sand $(49 \%)$ & $\begin{array}{c}\text { Bag House Fines } \\
(1 \%)\end{array}$ \\
\hline All Skid & 99 & Skid & Skid & Skid & Non-Skid \\
\hline Opposite Skid & 59 & Non-Skid & Skid & Skid & Non-Skid \\
\hline Per Design & 40 & Skid & Non-Skid & Non-Skid & Non-Skid \\
\hline No Skid & 0 & Non-Skid & Non-Skid & Non-Skid & Non-Skid \\
\hline
\end{tabular}

\section{Insoluble Residue Test}

The WVDOH uses the insoluble residue (IR) test, WVDOH MP 703.00.29, to evaluate carbonate aggregates for use as skid resistant aggregates for wearing surfaces of pavements with an ADT of 3000 or more. The aggregates used in the mixes from the skid resistant experiment were evaluated using MP 703.00.29. The samples for the IR test were obtained by burning of the $\mathrm{G}_{\mathrm{mm}}$ samples used in the skid resistant experiment, following AASHTO T 308.

MP 703.00.29 specifies grinding down the aggregate sample to pass the No. 16 sieve. The IR test is then performed on the reduced material that is retained on the No. 30 sieve. For research purposes the IR of two additional gradations:

- the material passing the No. 30 and retained on the No. 200

- all the material passing the No. 16 and retained on the No. 200 sieve.

A total of 24 samples were evaluated based on four mix types, three test protocols, and two replicate samples. The amount of quartz material was observed, and the percentage of quartz was subjectively chosen from the comparison chart in the material procedure, shown in Figure 5. Measurements collected are provided in Appendix D. 


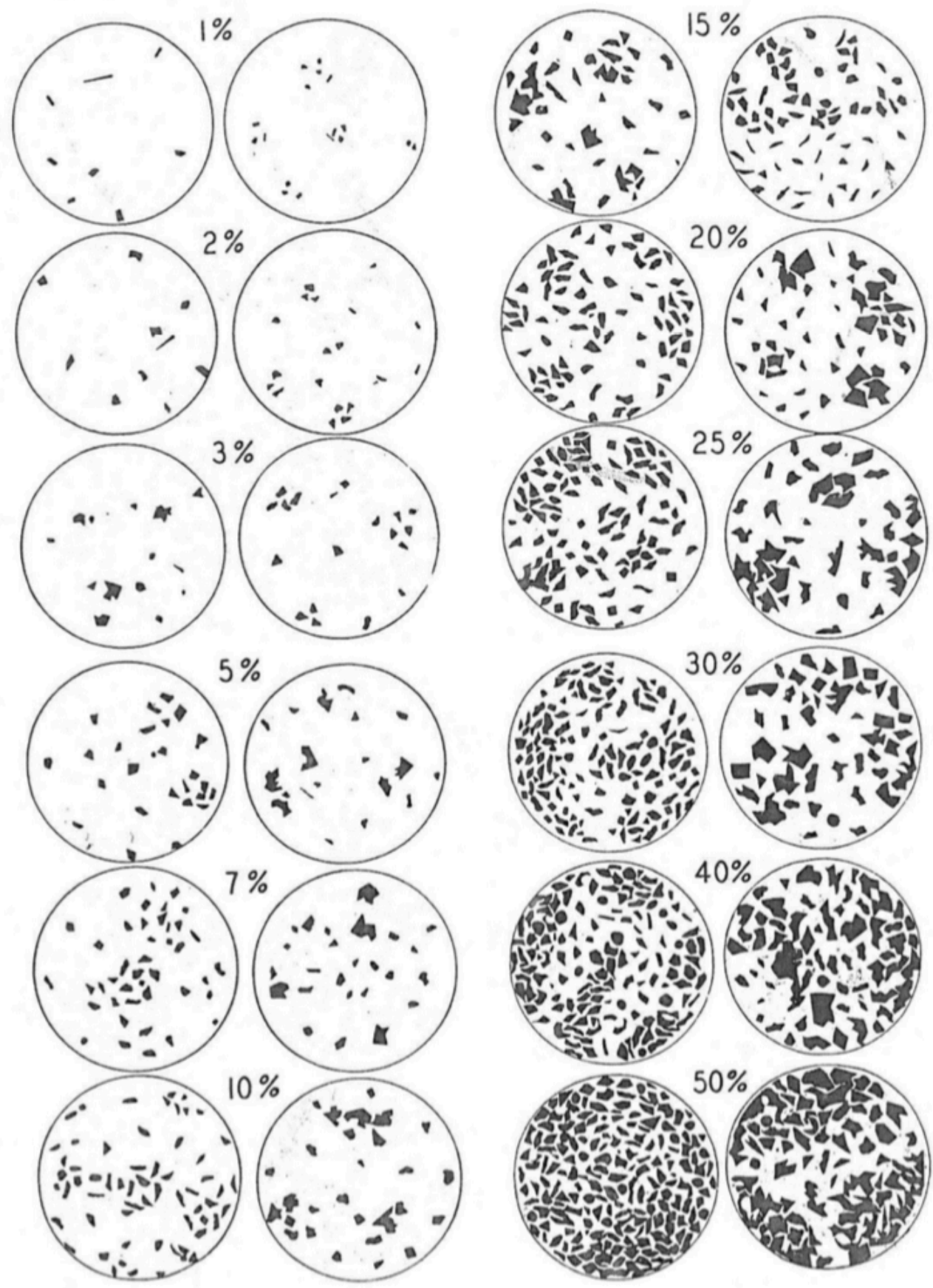

Figure 5: Comparison Chart for Estimation of Percentage Composition (WVDOH MP 703.00.29) 


\section{Chapter 4: Results and Discussion}

This section presents the results and provides discussion of the results found. The first section compares the results from the original experiment to the current replicate experiment to test repeatability. The second section concludes and compares the skid resistant aggregate experiment results to the insolubility residue test results. The data recorded for the results are displayed in the Appendix.

\section{Comparison for Repeatability}

Figures 6 to 9 compare the original polishing results to the replicate results for 48,000 wheel passes for the different variables in the experiment.

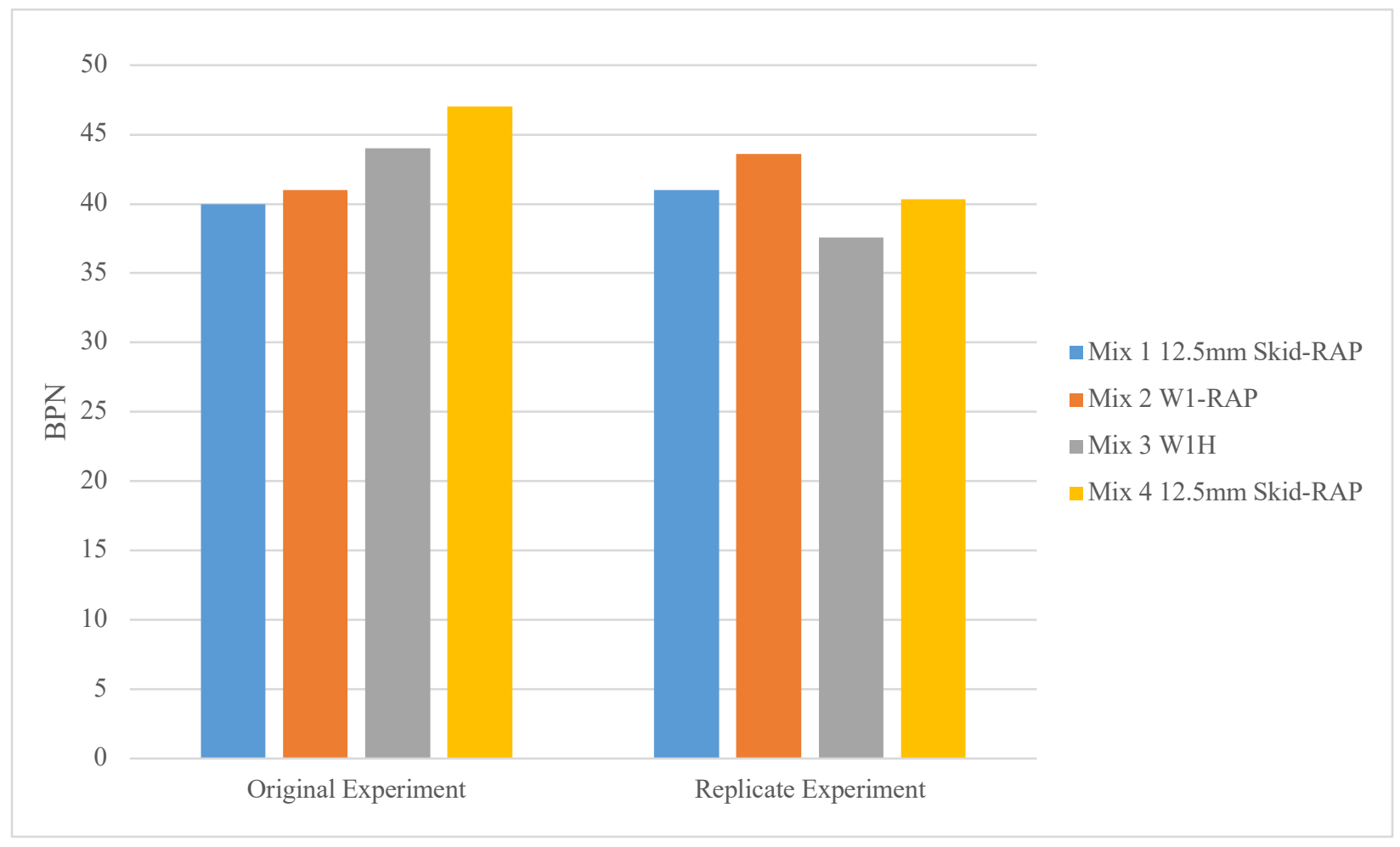

Figure 6: Average BPN After 48,000 Wheel Passes at 4\% VTM with High Toe 


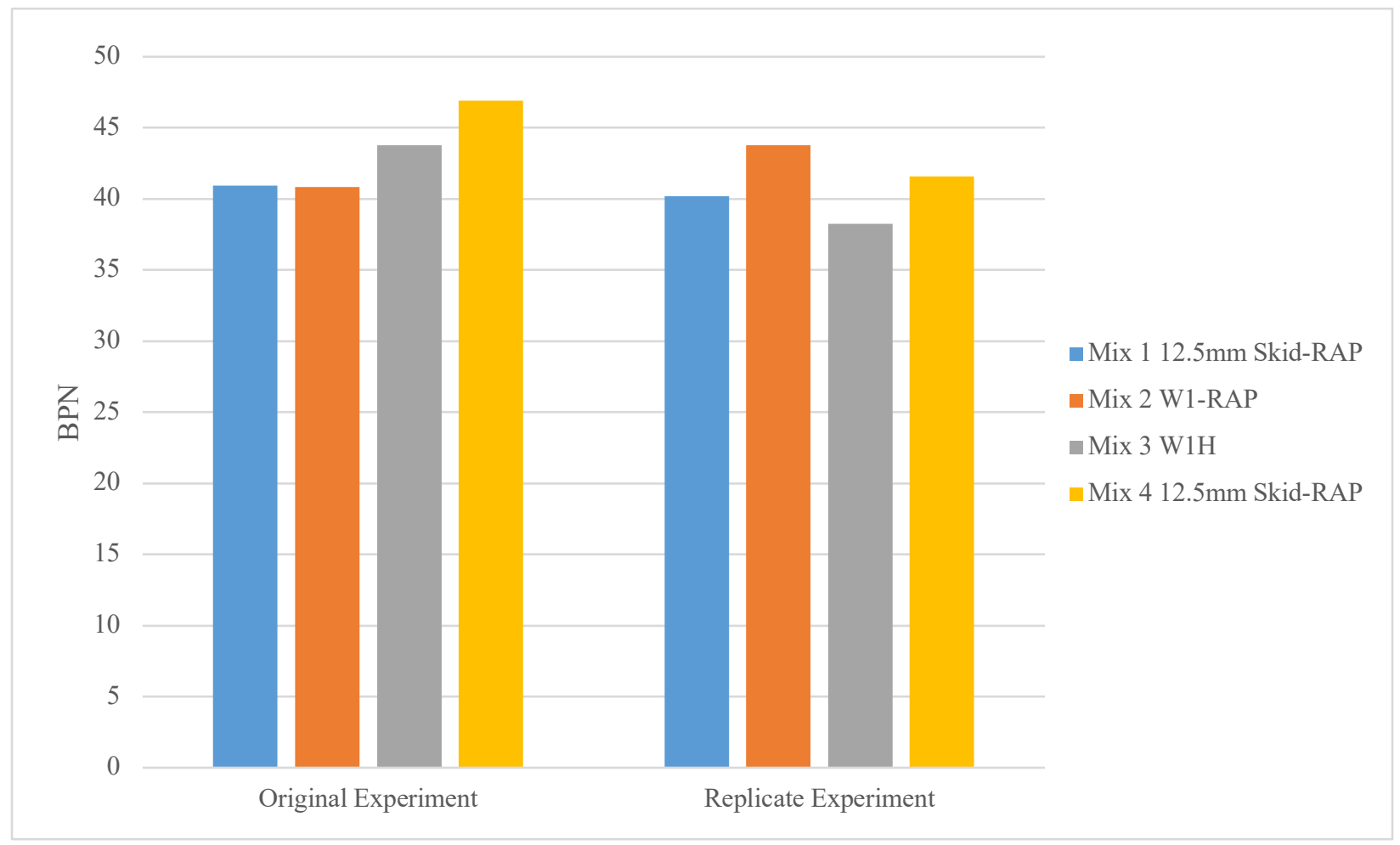

Figure 7: Average BPN After 48,000 Wheel Passes at 8\% VTM with High Toe

60

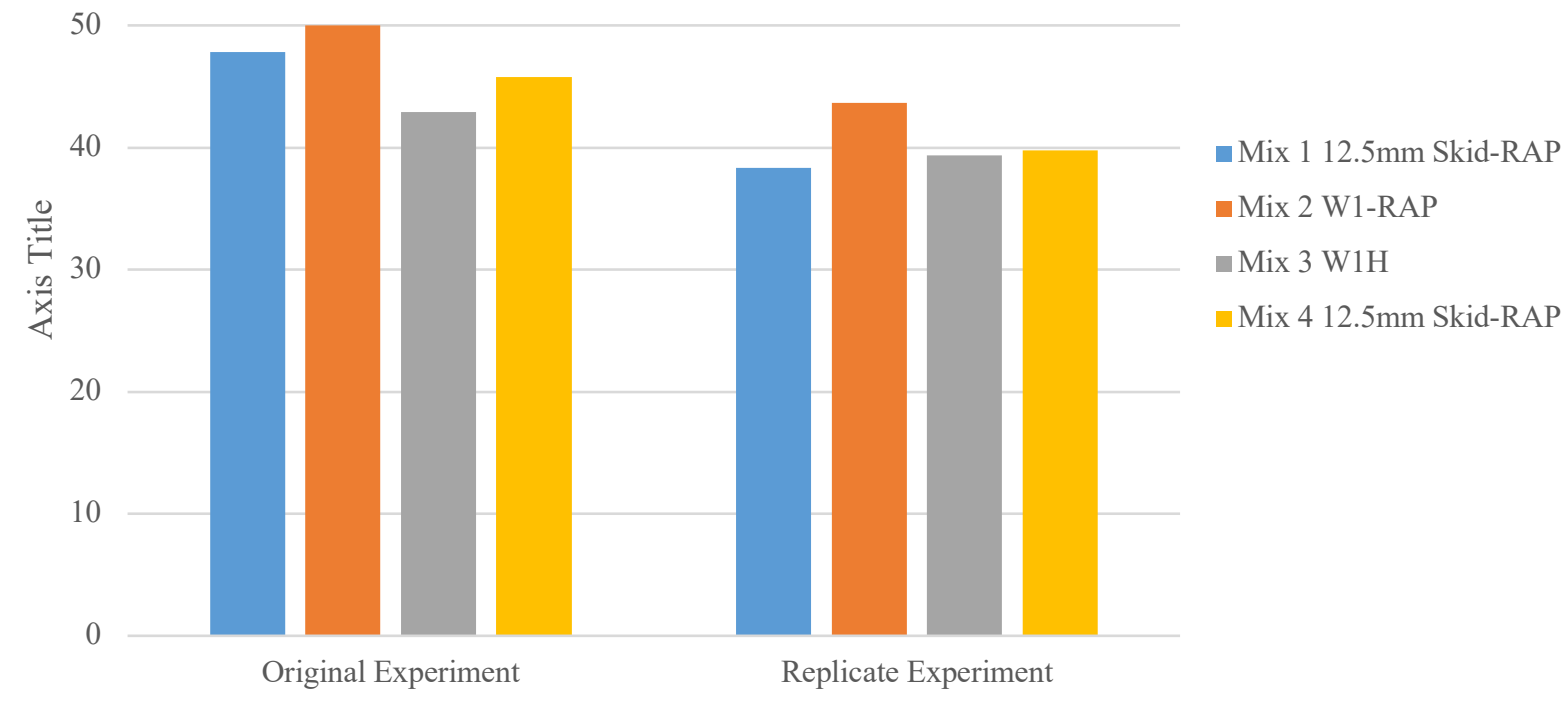

Figure 8: Average BPN After 48,000 Wheel Passes at 4\% VTM with Low Toe 


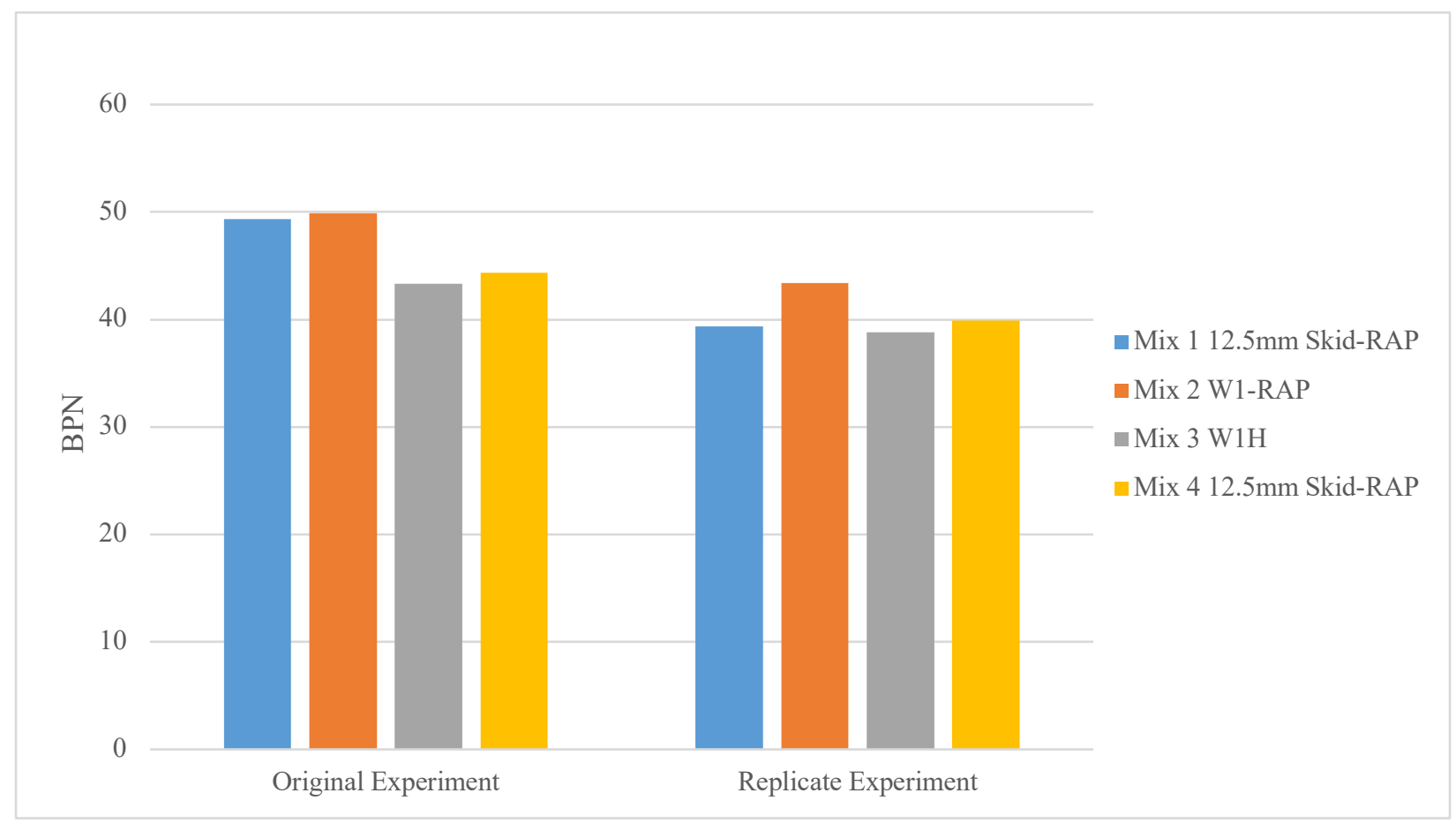

Figure 9: Average BPN After 48,000 Wheel Passes at 8\% VTM with Low Toe

The statistical analysis using the t-Test: Two Sample Assuming Equal Variances data analysis in Excel produced the results in Table 5.

Table 5: Statistical comparison for original vs. replicate results

\begin{tabular}{lcc}
\hline & Original & Replicate \\
\hline Mean & 44.8 & 40.5 \\
Variance & 11.1 & 4.4 \\
Observations & 48 & 48 \\
Pooled Variance & 7.75 & \\
Hypothesized Mean Difference & 0 & \\
df & 94 & \\
t Stat & 7.58 & \\
P $(\mathrm{T}<=$ t) one-tail & $1.20 \mathrm{E}-11$ & \\
t Critical one-tail & 1.66 & \\
$\mathrm{P}(\mathrm{T}<=\mathrm{t})$ two-tail & $\mathbf{2 . 4 1 E}-11$ & \\
$\mathrm{t} \mathrm{Critical} \mathrm{two-tail}$ & 1.99 & \\
\hline
\end{tabular}


The statistical comparison shows that the two-tail $p$-value is less than $\alpha=0.05$, so the null hypothesis of equal means is rejected. This concludes the test is not repeatable and further research is needed to refine the polishing protocol. Figure 10 compares the average BPN of the original experiment to the replicate experiment by finding the line of regression for the data.

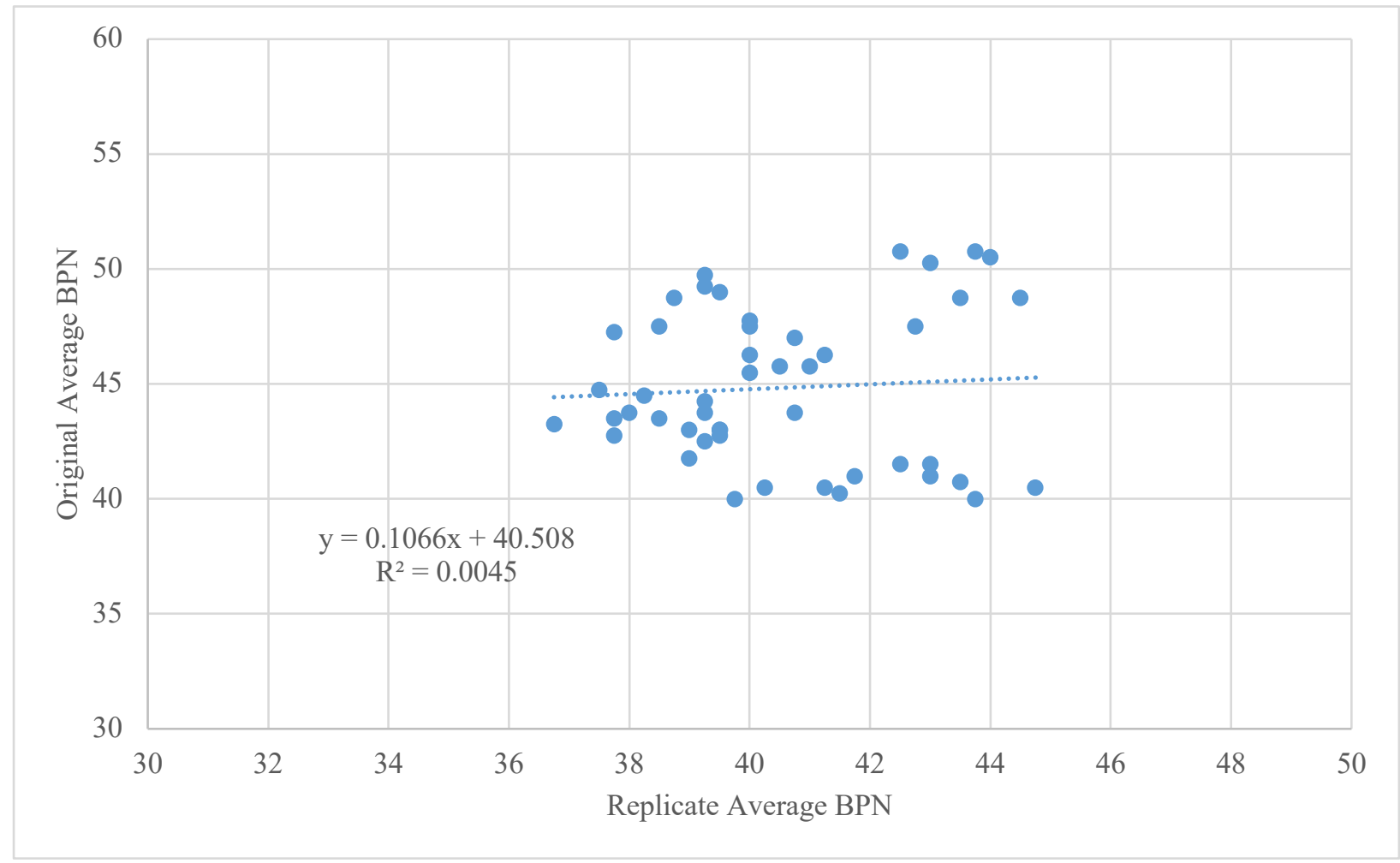

Figure 10: Average BPN Comparison for Original vs. Replicate

To show similar results with a line of regression, a preferred y intercept is 0 and a preferred slope is $1 \mathrm{x}$. The $\mathrm{y}$ intercept from this chart is 40.508 , and the slope of the line is $0.1066 \mathrm{x}$. The $\mathrm{R}^{2}$ value for this chart equals 0.0045 , showing that a low percentage of the data fit the line of regression.

\section{Skid Resistant Asphalt Results}

The progression of polishing for the Per Design \#1 sample is shown in Figure 11. The illustration shows aggregates becoming more visible as the number of wheel passes increases. 

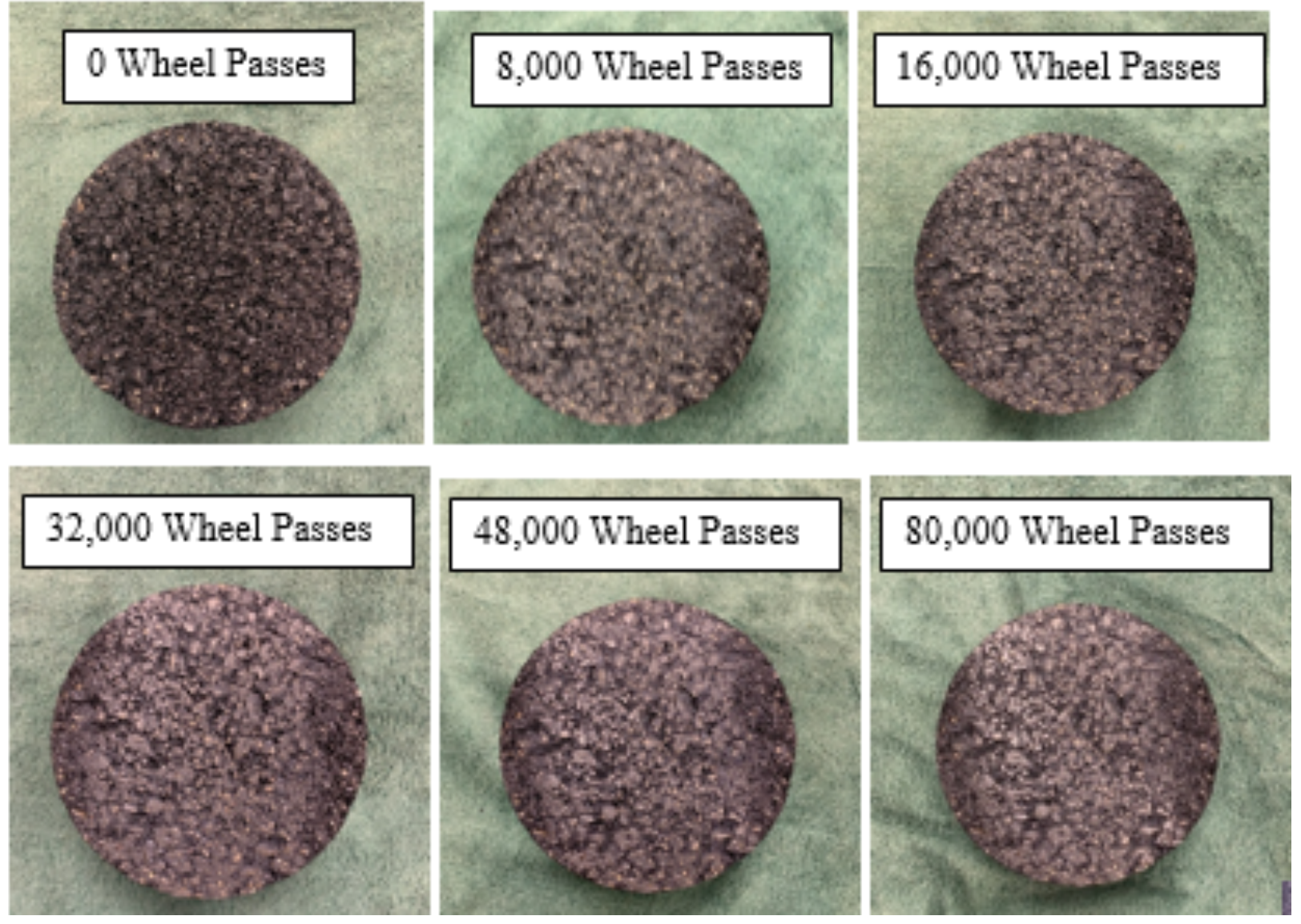

Figure 11: Progression of polishing

The general trend of decreasing BPN with polishing cycles is shown on Figures 12 and 13 for high toe and low toe, respectively. The results for the different mixes appears to be similar. 


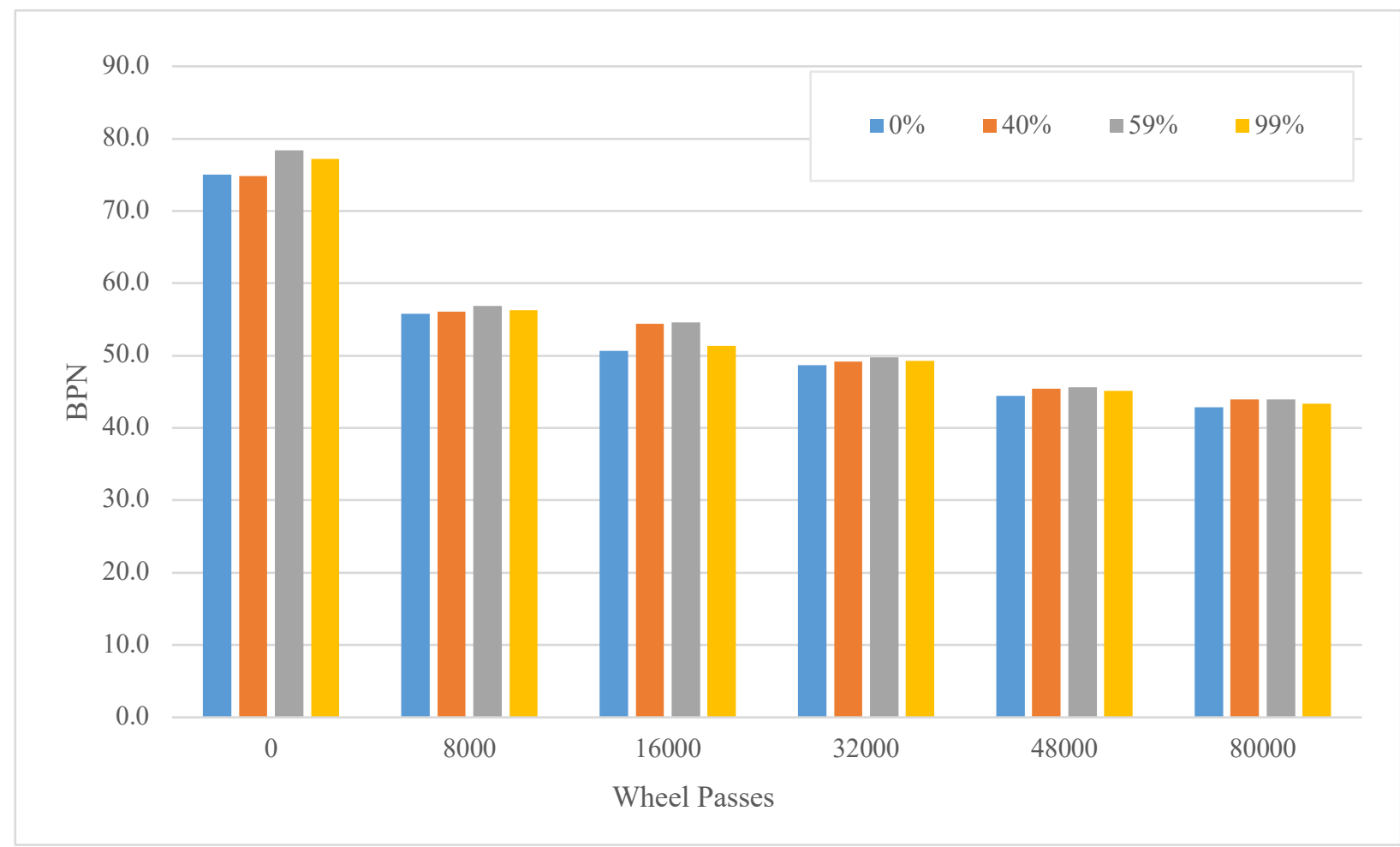

Figure 12: Average BPN Numbers for $9.5 \mathrm{~mm}$ SKID Study at 7\% VTM with High Toe

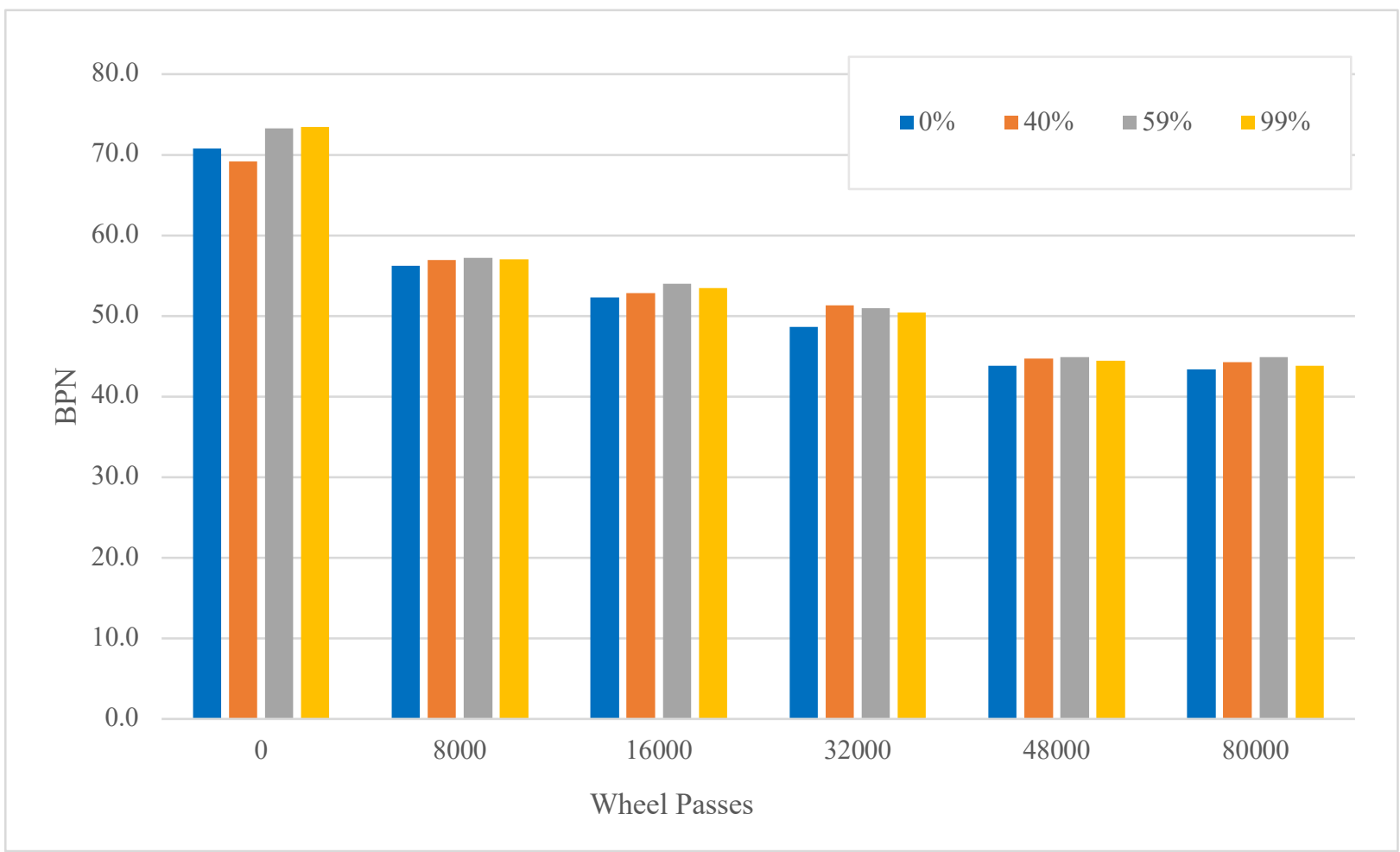

Figure 13: Average BPN Numbers for $9.5 \mathrm{~mm}$ SKID Study at 7\% VTM with Low Toe 
The comparison of the specimen at 80,000 wheel passes is shown in Figure 14. The summary of results from the skid resistant asphalt experiment at 80,000 wheel passes is shown in Table 6. The results are very similar. The average BPN and standard deviation of each sample type are shown in Table 6 . The mixture with 59\% skid resistant aggregates performed slightly higher than other mixtures.

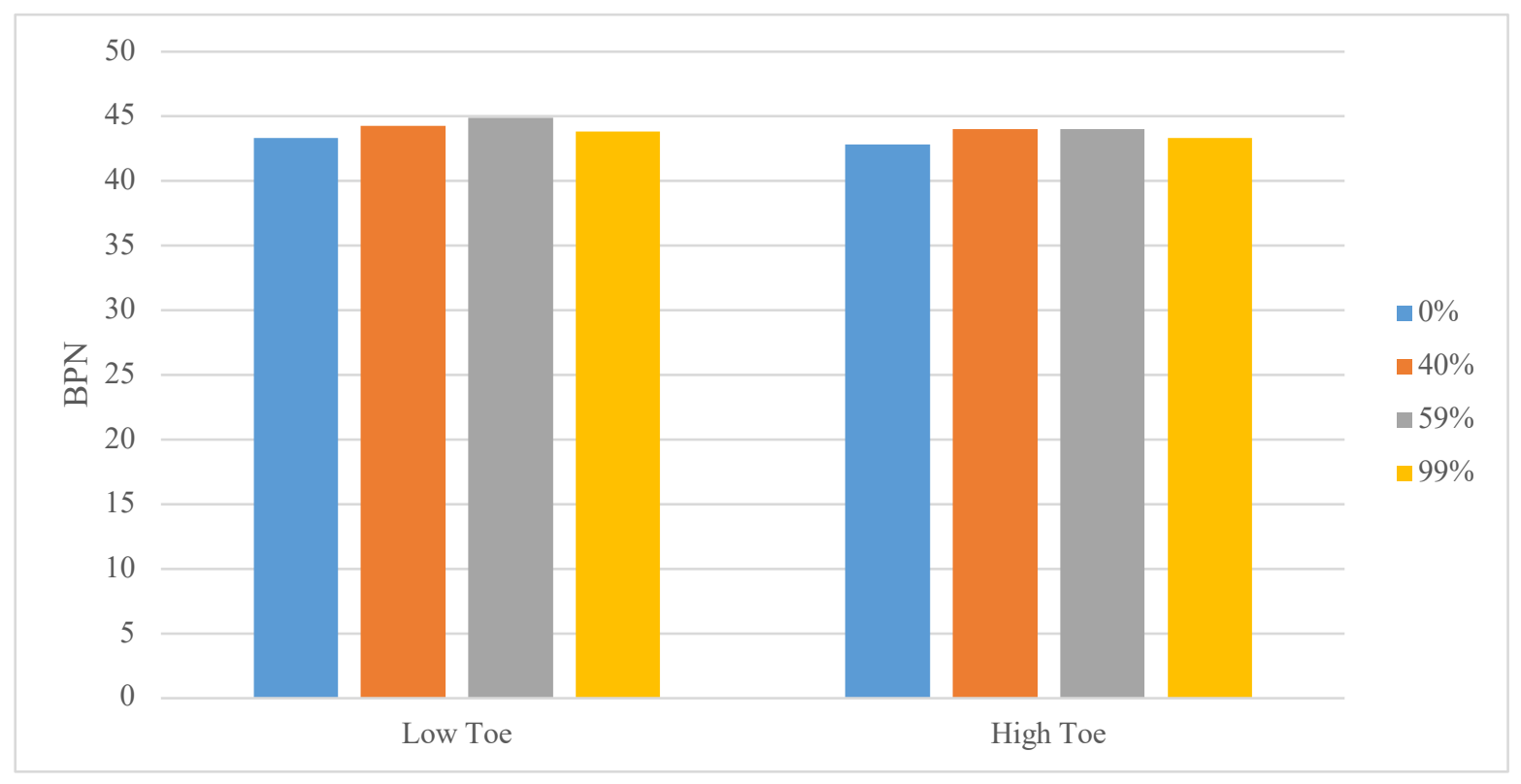

Figure 14: Average BPN per specimen for Low Toe and High Toe after 80,000 Wheel Passes 
Table 6: BPN Average and Standard Deviation

\begin{tabular}{|c|c|c|c|c|c|}
\hline & Mix & Sample & $\begin{array}{c}\text { Average of } 4 \\
\text { BPN } \\
\text { Measurements }\end{array}$ & $\begin{array}{c}\text { Average of } \\
\text { Samples }\end{array}$ & $\begin{array}{c}\text { Standard } \\
\text { Deviation }\end{array}$ \\
\hline \multirow{12}{*}{$\begin{array}{l}\text { Bottom } \\
\text { Low Toe }\end{array}$} & \multirow{3}{*}{ Per Design } & 1 & 44.3 & \multirow{3}{*}{44.3} & \multirow{3}{*}{1.00} \\
\hline & & 2 & 43.3 & & \\
\hline & & 3 & 45.3 & & \\
\hline & \multirow{3}{*}{$\begin{array}{l}\text { Opposite } \\
\text { Skid }\end{array}$} & 1 & 46.0 & \multirow{3}{*}{44.9} & \multirow{3}{*}{1.13} \\
\hline & & 2 & 45.0 & & \\
\hline & & 3 & 43.8 & & \\
\hline & \multirow{3}{*}{ No Skid } & 1 & 42.5 & \multirow{3}{*}{43.3} & \multirow{3}{*}{1.04} \\
\hline & & 2 & 44.5 & & \\
\hline & & 3 & 43.0 & & \\
\hline & \multirow{3}{*}{ All Skid } & 1 & 45.0 & \multirow{3}{*}{43.8} & \multirow{3}{*}{1.26} \\
\hline & & 2 & 42.5 & & \\
\hline & & 3 & 44.0 & & \\
\hline \multirow{12}{*}{$\begin{array}{c}\text { Tops } \\
\text { High Toe }\end{array}$} & \multirow{3}{*}{ Per Design } & 1 & 44.3 & \multirow{3}{*}{44.0} & \multirow{3}{*}{0.43} \\
\hline & & 2 & 44.3 & & \\
\hline & & 3 & 43.5 & & \\
\hline & \multirow{3}{*}{$\begin{array}{l}\text { Opposite } \\
\text { Skid }\end{array}$} & 1 & 44.5 & \multirow{3}{*}{44.0} & \multirow{3}{*}{0.43} \\
\hline & & 2 & 43.8 & & \\
\hline & & 3 & 43.8 & & \\
\hline & \multirow{3}{*}{ No Skid } & 1 & 42.0 & \multirow{3}{*}{42.8} & \multirow{3}{*}{0.88} \\
\hline & & 2 & 42.8 & & \\
\hline & & 3 & 43.8 & & \\
\hline & \multirow{3}{*}{ All Skid } & 1 & 44.0 & \multirow{3}{*}{43.3} & \multirow{3}{*}{0.63} \\
\hline & & 2 & 42.8 & & \\
\hline & & 3 & 43.3 & & \\
\hline
\end{tabular}

The further statistics that were performed on the average BPN results using a t-Test: Two-Sample Assuming Equal Variances in Excel are shown below in Table 7. This test compared the results of the average BPN when using low toe and high toe. 
Table 7: $\mathrm{t}$-Test results for average BPN of specimen at 80,000 wheel passes

\begin{tabular}{lcc}
\hline & Low Toe & High Toe \\
\hline Mean & 44.1 & 43.5 \\
Variance & 1.27 & 0.54 \\
Observations & 12 & 12 \\
Pooled Variance & 0.904 & \\
Hypothesized Mean Difference & 0 & \\
df & 22 & \\
t Stat & 1.40 & \\
P $(\mathrm{T}<=$ t) one-tail & 0.088 & \\
t Critical one-tail & 1.72 & \\
P $(\mathrm{T}<=\mathrm{t})$ two-tail & $\mathbf{0 . 1 7 7}$ & \\
t Critical two-tail & 2.07 & \\
\hline
\end{tabular}

This statistical comparison shows that the $p$-value is greater than $\alpha=0.05$, so there is insufficient evidence to reject the null hypothesis; indicating the test results for each toe angle are statistically similar.

The average BPN versus percent skid aggregate is shown in Figure 15. The graph appears to show a slight trend of increasing BPN with percent skid aggregate up to 40 to 59 percent aggregate then decreases to the 99 percent skid aggregate mix. However, with the amount of variability in the test results it cannot be concluded that there is a correlation between BPN and percent skid aggregate.

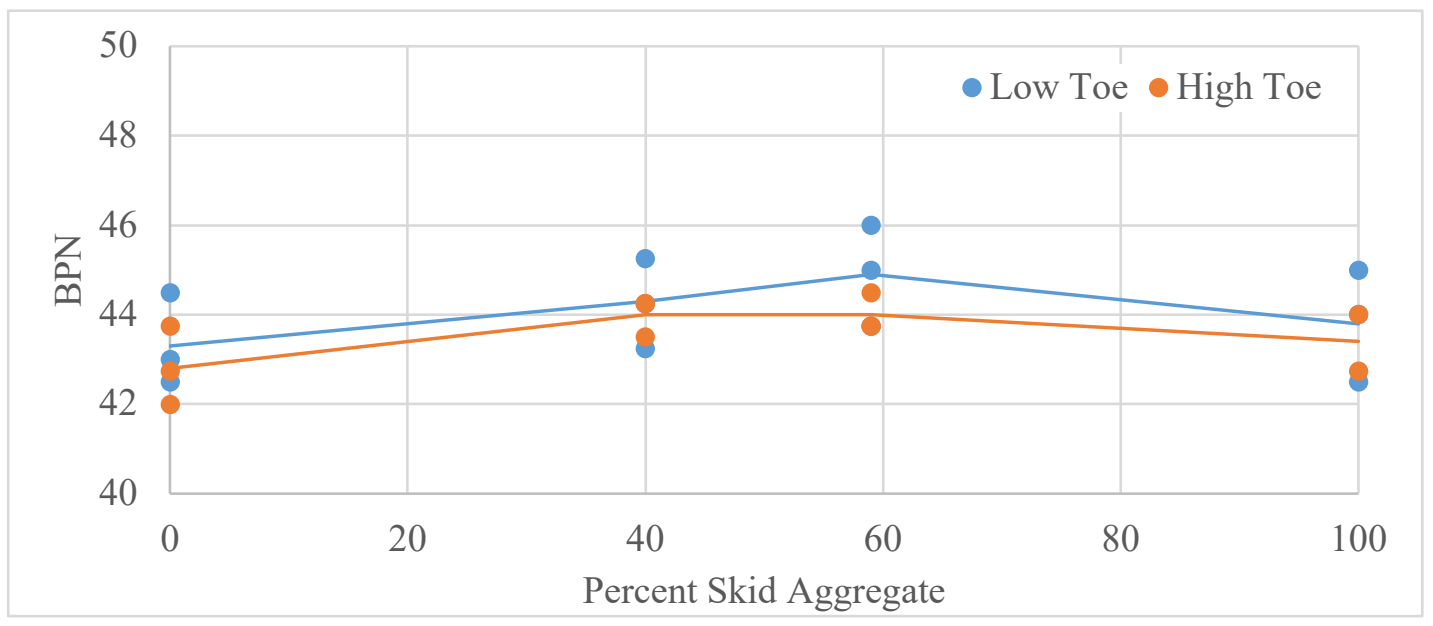

Figure 15: Skid Aggregate Content vs. Average BPN 
The results from the insoluble residue test also indicate that average BPN value does not increase as the percentage of skid resistant aggregates increases. Table 8 displays the summary of results from the three insoluble residue tests. The percentage of insoluble aggregates found in the All Skid mixture is the largest in all three test methods, as expected. The Opposite Skid was expected to have the third largest percentage of insoluble residue, but instead, Per Design shows a larger percentage. This was expected for the method following the WVDOH precisely, but the other two methods were thought to be more representative of the sample. The WVDOH method only uses larger sized aggregates during testing, so the Opposite Skid was expected to show less insoluble residue since the skid aggregates pass through the desired sieve size. Figure 16 illustrates the insoluble residue values from the state approved WVDOH MP 703.00.29 and the additional variations of tests per each skid aggregate content.

Table 8: Summary of average Insoluble Residue results per sample for each method

\begin{tabular}{|c|c|c|c|c|}
\hline & \multicolumn{4}{|c|}{+200 Qtz.,\%: Per Sample Averages } \\
\cline { 2 - 5 } & All Skid & Opposite Skid & Per Design & No Skid \\
\hline $\begin{array}{c}\text { Percent Skid } \\
\text { Aggregate }\end{array}$ & 99 & 59 & 40 & 0 \\
\hline DOH Method & 12 & 3 & 11 & 1 \\
\hline Under DOH & 24 & 9 & 22 & 5 \\
\hline Total IR & 18 & 11 & 13 & 6 \\
\hline
\end{tabular}

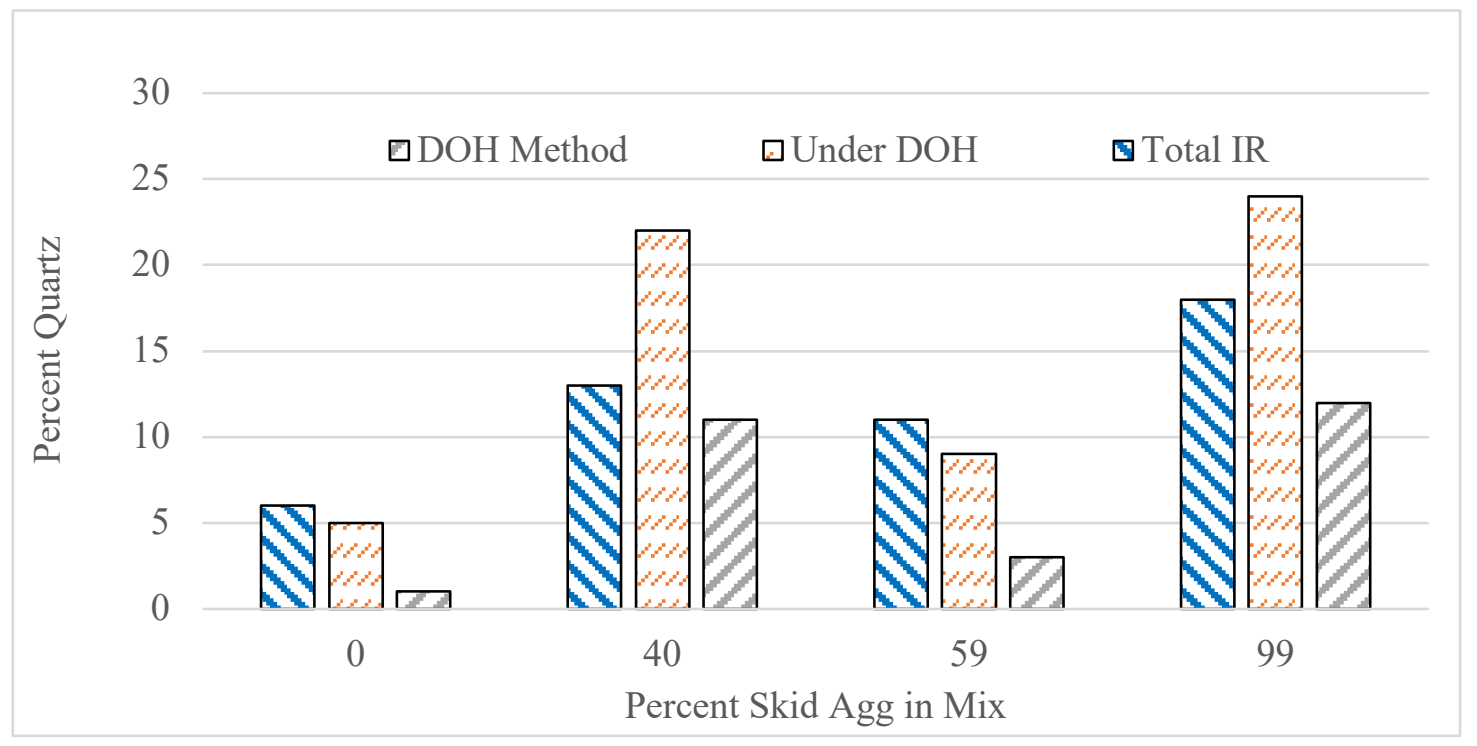

Figure 16: Skid Aggregate Content vs. +200 Quartz Insoluble Residue 
Comparing the values from the test following the DOH Method, it can be seen the average BPN values for each sample do not correlate to the insoluble reside results. These results can be seen in Table 9. Table 10 shows how these results compare to each other when ranked. The Per Design and No Skid had consistent rankings, but the All Skid and Opposite Skid had varying rankings.

Table 9: Insoluble Residue (\% Quartz) vs. Average BPN

\begin{tabular}{|c|c|c|c|}
\cline { 2 - 4 } \multicolumn{1}{c|}{} & $\begin{array}{c}\text { IR value } \\
\text { (\% Qtz) }\end{array}$ & $\begin{array}{c}\text { High Toe } \\
\text { Average BPN }\end{array}$ & $\begin{array}{c}\text { Low Toe } \\
\text { Average BPN }\end{array}$ \\
\hline All Skid & 12 & 43.3 & 43.8 \\
\hline Opposite Skid & 3 & 44.0 & 44.9 \\
\hline Per Design & 11 & 44.0 & 44.3 \\
\hline No Skid & 1 & 42.8 & 43.3 \\
\hline
\end{tabular}

Table 10: Ranking of IR and BPN

\begin{tabular}{|c|c|c|}
\cline { 2 - 3 } \multicolumn{1}{c|}{} & IR Ranking & $\begin{array}{c}\text { Average BPN } \\
\text { Ranking }\end{array}$ \\
\hline All Skid & 1 & 3 \\
\hline Opposite Skid & 3 & 1 \\
\hline Per Design & 2 & 2 \\
\hline No Skid & 4 & 4 \\
\hline
\end{tabular}


Figure 17 displays example images of the microscopic view for various sample mixtures and sieve sizes. These images were compared to the comparison chart in the MP 703.00.29, Figure 5, to determine the insoluble residue contents.

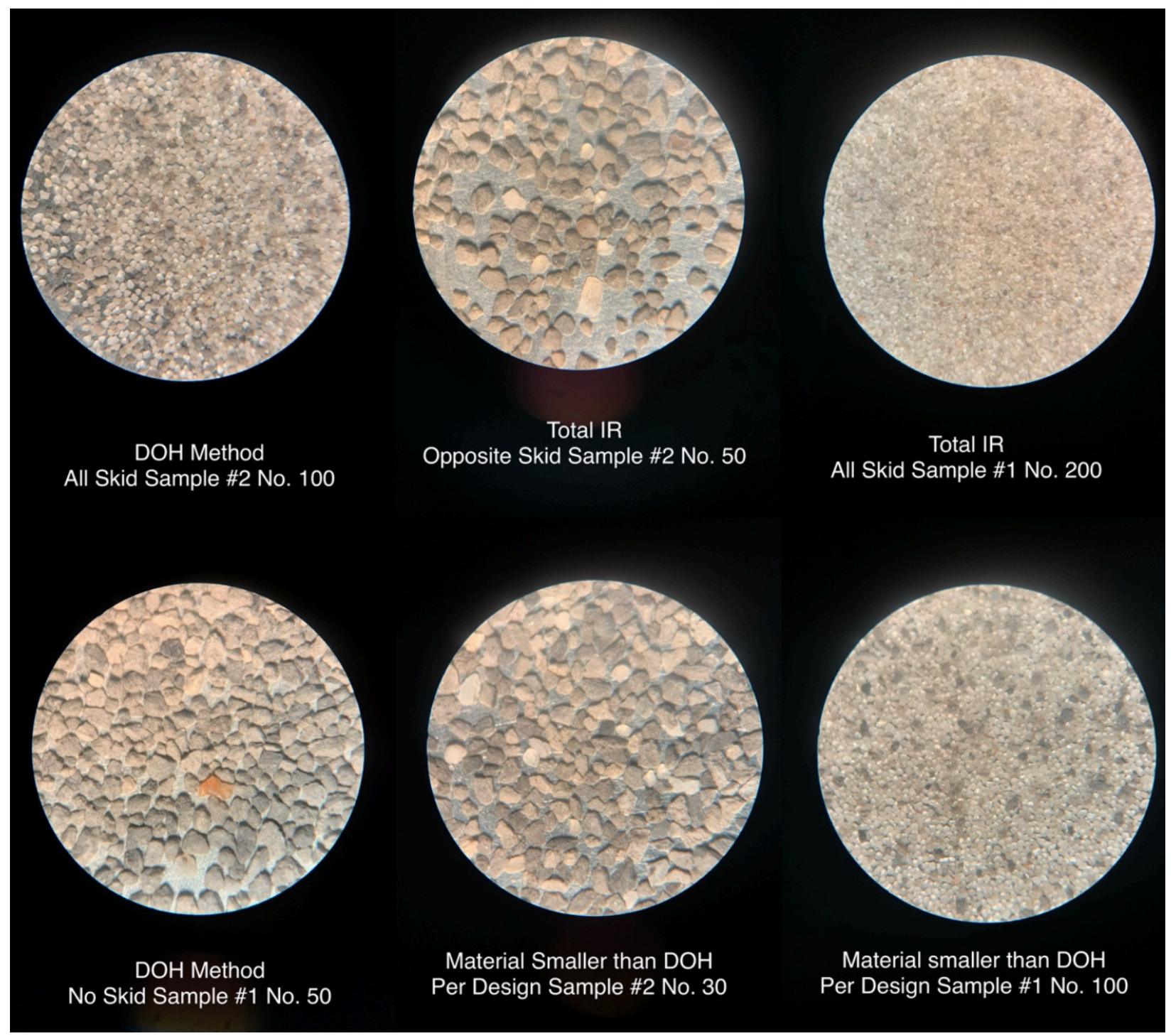

Figure 17: Microscopic view of Insoluble Residue 


\section{Chapter 5: Conclusions and Recommendations}

\section{Conclusions}

This research had multiple objectives pertaining to skid resistant aggregates and their microtexture properties. The testing was performed using the CTPM and the BPT, aside from the insoluble residue portion.

During the repeatability test, all procedures were carefully followed exactly as the previous experimenter. The preparation of the samples was performed in the same way and tested in the same order. Discrepancies in the data could have happened in the polishing process or during testing. Since the testing procedure with the BPT involves applying 30 sprays of water, this could have affected the BPN. The amount of 1 spray could have varied by experimenter. Having a way of applying an exact amount of water each time could change the variances in the results. One mixture during testing was inconsistent during compaction; the desired VTM was difficult to achieve. This could have affected the way the asphalt polished, creating different results and different statistics.

During the skid resistant aggregate experiment, the average BPN results for each mixture type were very similar to each other, suggesting that there is no difference in their performance is regards to microtexture using the BPT.

When determining the insoluble residue content, the results show that there are no correlations to the amount of apparent skid aggregates in the mix and the amount found after the insoluble residue test. Since the test is very subjective to the one performing the test, the content of the insoluble residue could be different.

The data collected from this study result in the following conclusions:

- The null hypothesis that the polishing method is repeatable is false.

- Further research is needed to refine the polishing procedure.

- There is no correlation between the microtexture skid resistance performance of asphalt and the amount of skid resistant aggregate in the mixture when using the BPT. 
- Insoluble residue percentage does not correlate to the average BPN.

- Ranking of the mixtures was inconsistent between the Polishing and IR methods.

\section{Recommendations}

Additional research of various friction measurements is needed. When finding the skid resistance of a pavement, testing should be performed at a higher speed in order to mimic traffic that travels at a higher speed. The BPT is used for low speed testing. A device for high speed testing should be used to accurately mimic the effects of skid resistant aggregates in asphalt.

The data for the skid aggregate samples was taken using a mix design from a single contractor. It is recommended to do the testing with the same mix designs made from other contractors to see if all mixes would perform the same as the specimens in this experiment. Running additional cycles in the polishing machine to polish of more binder and expose aggregate could produce different results as well. Additionally, the WVDOH should consider using other methods for evaluating friction and skid resistance for laboratory testing. 


\section{References}

Ahmad, Shaheer. 2015. "Experiment No.6, To Measure Surface Frictional Properties Using British Pendulum Skid Resistance Tester.” Accessed March 12, 2020. https://www.academia.edu/37842764/To_Measure_Surface_Frictional_Properties_Using _British_Pendulum_Skid_Resistance_Tester

Chen, X., Dai, S., Guo, Y., Yang, J., and Huang, X., "Polishing of Asphalt Pavements: From Macro- to Micro- Scale,” Journal of Testing and Evaluation, Vol. 44, No. 2, 2016, pp. 885-894, doi:10.1520/JTE20150271. ISSN 0090-3973

Dahir, S. H. M. and Mullen, W.G. 1971 "Factors Influencing Aggregate Skid-Resistance Properties.” http://onlinepubs.trb.org/Onlinepubs/hrr/1972/376/376-022.pdf

Federal Highway Administration. February 20, 2020. "How Do Weather Events Impact Roads?." Accessed March 2, 2020. https://ops.fhwa.dot.gov/weather/q1_roadimpact.htm

Federal Highway Administration. June 17, 2005. "Technical Advisory T 5040.36 Surface Texture for Asphalt and Concrete Pavements.” Accessed March 2, 2020. https://www.fhwa.dot.gov/pavement/t504036.cfm

Federal Highway Administration Research and Technology. February 2015. "Evaluation of Pavement Safety Performance.” Accessed March 3, 2020. https://www.fhwa.dot.gov/publications/research/safety/14065/002.cfm

Henry, John. (2000). "Evaluation of Pavement Friction Characteristics." NCHRP Synthesis 291.

Hoyer, D. (2020) "Procedure for Asphalt Mixture Friction Evaluation for WVDOH." West Virginia University

Jayawickrama, Priyantha W., Rachakatla, P., and Thomas, B. September 1998. "A Comprehensive Methodology for Predicting Field Skid Resistance of Bituminous Aggregates Based on Laboratory Test Data as Well as Their Skid Performance.” Texas Tech University. https://library.ctr.utexas.edu/hostedpdfs/texastech/0-1459-5f.pdf

Liang, Robert Y. August 2003. "Blending Proportions of High Skid and Low Skid Aggregate." The University of of Akron. http://www.dot.state.oh.us/Divisions/Planning/SPR/Research/reportsandplans/Reports/20 03/Materials/14793-FR.pdf

Lu, Qing. (2006). Friction Testing of Pavement Preservation Treatments: Literature Review.

Masad, E., Rezaei, A., Chowdhury, A., and Harris, P. August 2009. "Predicting Asphalt Mixture Skid Resistance Based on Aggregate Characteristics." Texas Transportation Institute. https://static.tti.tamu.edu/tti.tamu.edu/documents/0-5627-1.pdf

Mataei, B., Zakeri, H., Zahedi, M. and Nejad, F.M. (2016) Pavement Friction and Skid Resistance Measurement Methods: A Literature Re- view. Open Journal of Civil Engineering, 6, 537-565. http://dx.doi.org/10.4236/ojce.2016.64046

O'Brien, Joan P., and Haddock, John E. September 2009. "Frictional Resistance of Aggregates for Hot-Mix Asphalt Pavements.” FHW A/IN/JTRP-2004/23. Purdue University. https://docs.lib.purdue.edu/cgi/viewcontent.cgi?article $=2563 \&$ context $=\mathrm{jtrp}$ 


\section{List of Test Methods Used}

AASHTO R 83: Preparation of Cylindrical Performance Test Specimens Using the Superpave Gyratory Compactor. Washington, DC: American Association of State Highway and Transportation Officials, 2018.

AASHTO T 166: Bulk Specific Gravity $(\mathrm{Gmm})$ of Compacted Asphalt Mixtures Using Saturated Surface-Dry Specimens. Washington, DC: American Association of State Highway and Transportation Officials, 2018.

AASHTO T 209: Theoretical Maximum Specific Gravity (Gmm) and Density of Hot Mix Asphalt (HMA). Washington, DC: American Association of State Highway and Transportation Officials, 2018.

AASHTO T 278: Surface Frictional Properties Using the British Pendulum Tester. Washington, DC: American Association of State Highway and Transportation Officials, 2018.

AASHTO T 308: Determining the Asphalt Binder Content of Asphalt Mixtures by the Ignition Method. Washington, DC: American Association of State Highway and Transportation Officials, 2018.

ASTM D3042: Standard Test Method for Insoluble Residue in Carbonate Aggregates. Pennsylvania: ASTM International, 2017.

ASTM E303: Standard Test Method for Measuring Surface Frictional Properties Using the British Pendulum Tester. Pennsylvania: ASTM International, 2018.

ASTM E660: Standard Practice for Accelerated Polishing of Aggregates or Pavement Surfaces Using a Small-Wheel, Circular Track Polishing Machine. Pennsylvania: ASTM International, 2015.

WVDOH MP 402.02.20: Rapid Determinations of the Polish Susceptible Carbonate Particle Content in Aggregates. West Virginia Department of Transportation, Division of Highways. 1995.

WVDOH MP 703.00.20: Determining Percent Quartz in Content Aggregates. West Virginia Department of Transportation, Division of Highways. 2018. 


\title{
Appendix A: Mix Design
}

\author{
Job Mix Formulas
}

$04-10$

WVDOH MCS\&T Approval

Recommended for Approval:

P. Cyrus

Approved By:

WEST VIRGINIA DIVISION OF HIGHWAYS

JOB MIX FORMULA FOR SUPERPAVE HOT-MIX ASPHALT

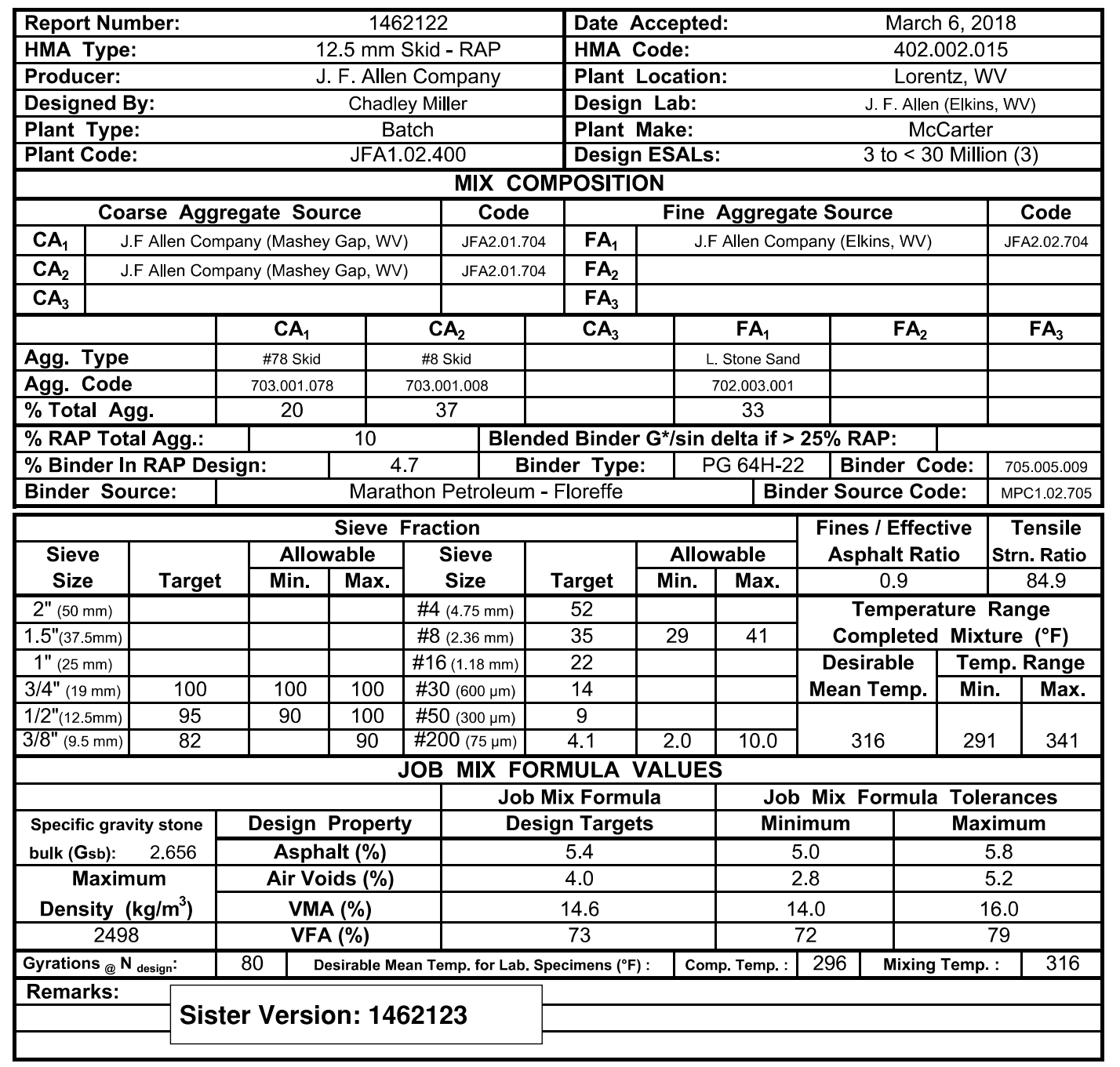

Figure 18: Job Mix Formula for J. F. Allen Co. $-12.5 \mathrm{~mm}$ SKID - RAP 


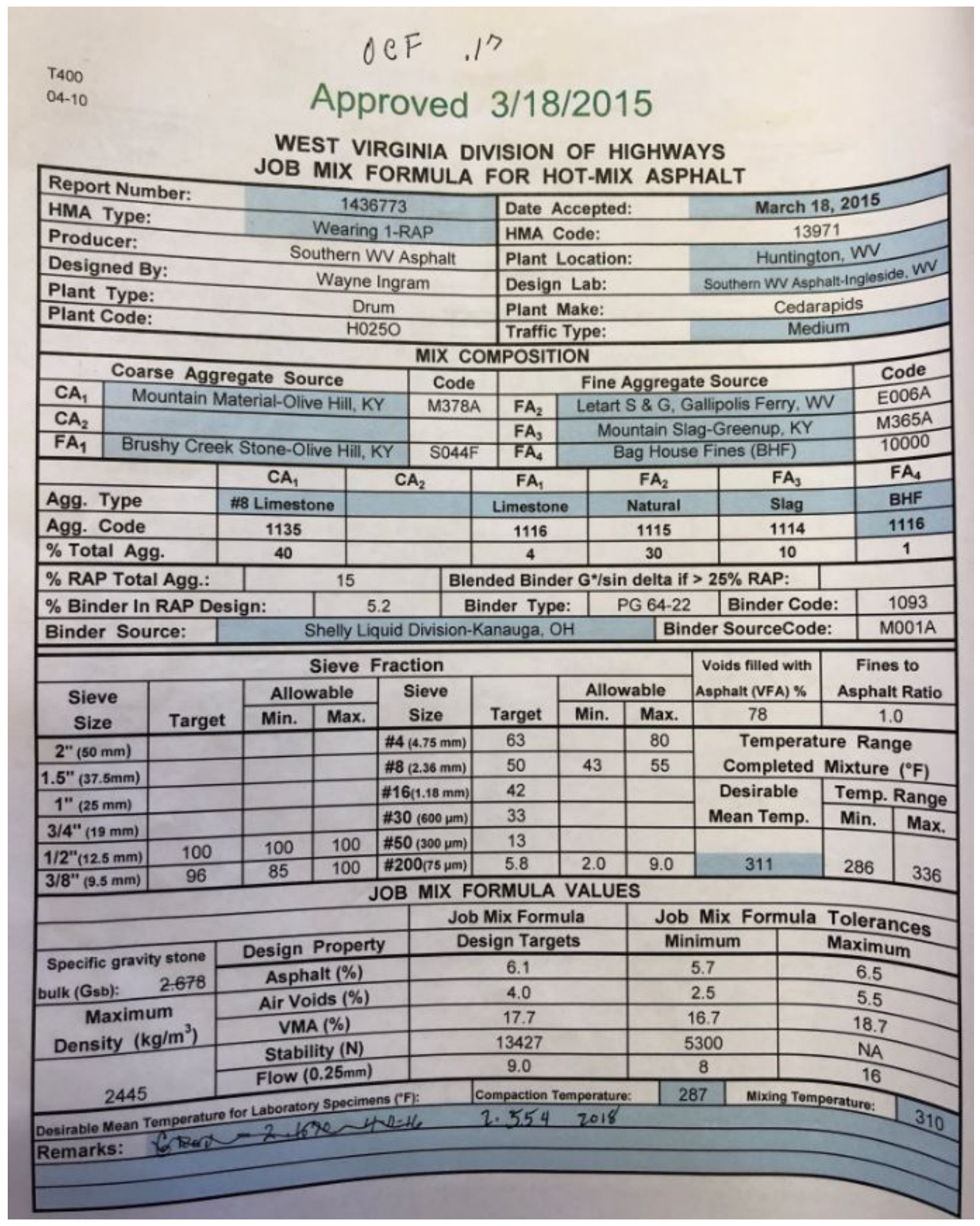

Figure 19: Job Mix Formula for West Virginia Paving, Inc. - Wearing $1-R A P$ 
WEST VIRGINIA DIVISION OF HIGHWAYS JOB MIX FORMULA FOR HOT-MIX ASPHALT

\begin{tabular}{|lc|lc|}
\hline Report Number: & \multicolumn{1}{l|}{ 1360465 } & Date Accepted: & March 9, 2004 \\
\hline HMA Type: & Wearing-1 & HMA Code: & 13966 \\
\hline Producer: & Greer Asphalt & Plant Location: & Greer, WV \\
\hline Designed By: & Rich Nuzum & Design Lab: & Clarksburg Asphalt \\
\hline Plant Type: & Batch & Plant Make: & McCarter \\
\hline Plant Code: & G012A & Traffic Type: & Heavy \\
\hline
\end{tabular}

\begin{tabular}{|c|c|c|c|c|c|c|c|c|}
\hline \multicolumn{9}{|c|}{ MIX COMPOSITION } \\
\hline \multicolumn{4}{|c|}{ Coarse Aggregate Source } & \multirow{2}{*}{$\begin{array}{c}\text { Code } \\
\text { G0120 }\end{array}$} & \multicolumn{3}{|c|}{ Fine Agg. / Mineral Filler Source } & \multirow{2}{*}{$\begin{array}{c}\text { Code } \\
\text { G0120 }\end{array}$} \\
\hline $\mathbf{C A}_{1}$ & \multicolumn{3}{|c|}{ Greer Industries, Greer, WV } & & $F_{1}$ & \multicolumn{2}{|c|}{ Greer Industries, Greer, WV } & \\
\hline $\mathbf{C A}_{2}$ & & & & & $\mathbf{F A}_{2}$ & \multicolumn{2}{|c|}{ Greer Industries, Greer, WV } & G0120 \\
\hline \multirow[t]{2}{*}{$\mathbf{C A}_{3}$} & & & & & $\mathbf{F A}_{3}$ & & & \\
\hline & & $\mathbf{C A}_{1}$ & & & $\mathbf{C A}_{3}$ & $\overline{F_{1}}$ & $\overline{F_{2}}$ & $\mathrm{FA}_{3}$ \\
\hline \multicolumn{2}{|c|}{ Agg. Type } & \#8 Limestone & & & & Limestone & Limestone & \\
\hline \multicolumn{2}{|c|}{ Agg. Code } & 1135 & & & & 1116 & 1116 & \\
\hline \multicolumn{2}{|c|}{$\%$ Total Agg. } & 48 & & & & 32 & 20 & \\
\hline \multicolumn{4}{|c|}{ \% RAP Total Agg.: } & Blen & d Bin & $\mathrm{G}^{*} /$ sin delta if & 25\% RAP: & \\
\hline \multicolumn{4}{|c|}{$\%$ Binder In RAP Design: } & Bin & er Typ & PG 64-22 & Binder Code: & 1093 \\
\hline \multicolumn{2}{|c|}{ Binder Source: } & \multicolumn{4}{|c|}{ Marathon/Ashland Oil, Floreffe, Pa. } & \multicolumn{2}{|c|}{ Binder SourceCode: } & $\mathrm{A} 022 \mathrm{~B}$ \\
\hline
\end{tabular}

\begin{tabular}{|c|c|c|c|c|c|c|c|c|c|c|}
\hline \multicolumn{8}{|c|}{ Sieve Fraction } & \multirow{3}{*}{\begin{tabular}{|c|}
$\begin{array}{l}\text { Voids filled with } \\
\text { Asphalt"VFA"(\%) }\end{array}$ \\
75 \\
\end{tabular}} & \multirow{3}{*}{\multicolumn{2}{|c|}{$\begin{array}{c}\begin{array}{c}\text { Fines to } \\
\text { Asphalt Ratio }\end{array} \\
0.8\end{array}$}} \\
\hline \multirow{2}{*}{$\begin{array}{l}\text { Sieve } \\
\text { Size }\end{array}$} & \multirow[b]{2}{*}{ Target } & \multicolumn{2}{|c|}{ Allowable } & \multirow{2}{*}{$\begin{array}{l}\text { Sieve } \\
\text { Size }\end{array}$} & \multirow[b]{2}{*}{ Target } & \multicolumn{2}{|c|}{ Allowable } & & & \\
\hline & & Min. & Max. & & & Min. & Max. & & & \\
\hline $2^{\prime \prime}(50 \mathrm{~mm})$ & & & & $\# 4(4.75 \mathrm{~mm})$ & 60 & & 80 & \multirow{2}{*}{\multicolumn{3}{|c|}{$\begin{array}{l}\text { Temperature Range } \\
\text { Completed Mixture }\left({ }^{\circ} \mathrm{F}\right)\end{array}$}} \\
\hline $1.5^{\prime \prime}(37.5 \mathrm{~mm})$ & & & & $\# 8(2.36 \mathrm{~mm})$ & 39 & 33 & 45 & & & \\
\hline $1^{\prime \prime}(25 \mathrm{~mm})$ & & & & $\# 16(1.18 \mathrm{~mm})$ & 23 & & & \multirow{2}{*}{\begin{tabular}{|c|} 
Desirable \\
Mean Temp.
\end{tabular}} & \multicolumn{2}{|c|}{ Temp. Range } \\
\hline $3 / 4^{\prime \prime}(19 \mathrm{~mm})$ & & & & $\# 30(600 \mu \mathrm{m})$ & 12 & & & & Min. & Max. \\
\hline $1 / 2^{\prime \prime}(12.5 \mathrm{~mm})$ & 100 & 100 & 100 & $\# 50(300 \mu \mathrm{m})$ & 7 & & & & & \\
\hline $3 / 8^{\prime \prime}(9.5 \mathrm{~mm})$ & 95 & 85 & 100 & $\# 200(75 \mu \mathrm{m})$ & 4.4 & 2.0 & 9.0 & 295 & 270 & 320 \\
\hline
\end{tabular}

\begin{tabular}{|c|c|c|c|c|}
\hline \multicolumn{5}{|c|}{ JOB MIX FORMULA VALUES } \\
\hline \multicolumn{3}{|c|}{ Job Mix Formula Targets } & \multicolumn{2}{|c|}{ Job Mix Formula Tolerances } \\
\hline Specific gravity stone & Design Property & Accepted Target & Minimum & Maximum \\
\hline bulk (Gsb): & Asphalt (\%) & 5.7 & 5.3 & 6.1 \\
\hline \multirow{2}{*}{$\begin{array}{c}\text { Maximum } \\
\text { Density }\left(\mathrm{kg} / \mathrm{m}^{3}\right)\end{array}$} & Air Voids (\%) & 4.0 & 2.5 & 5.5 \\
\hline & VMA (\%) & 15.7 & 14.7 & 16.7 \\
\hline \multirow[b]{2}{*}{2476} & Stability (N) & 10400 & 8000 & NA \\
\hline & Flow $(0.25 \mathrm{~mm})$ & 11 & 8 & 14 \\
\hline
\end{tabular}

Remarks:

Figure 20: Job Mix Formula for Greer - Wearing 1 Heavy 
WEST VIRGINIA DIVISION OF HIGHWAYS $03 / 14 / 2018$ JOB MIX FORMULA FOR SUPERPAVE HOT-MIX ASPHALT

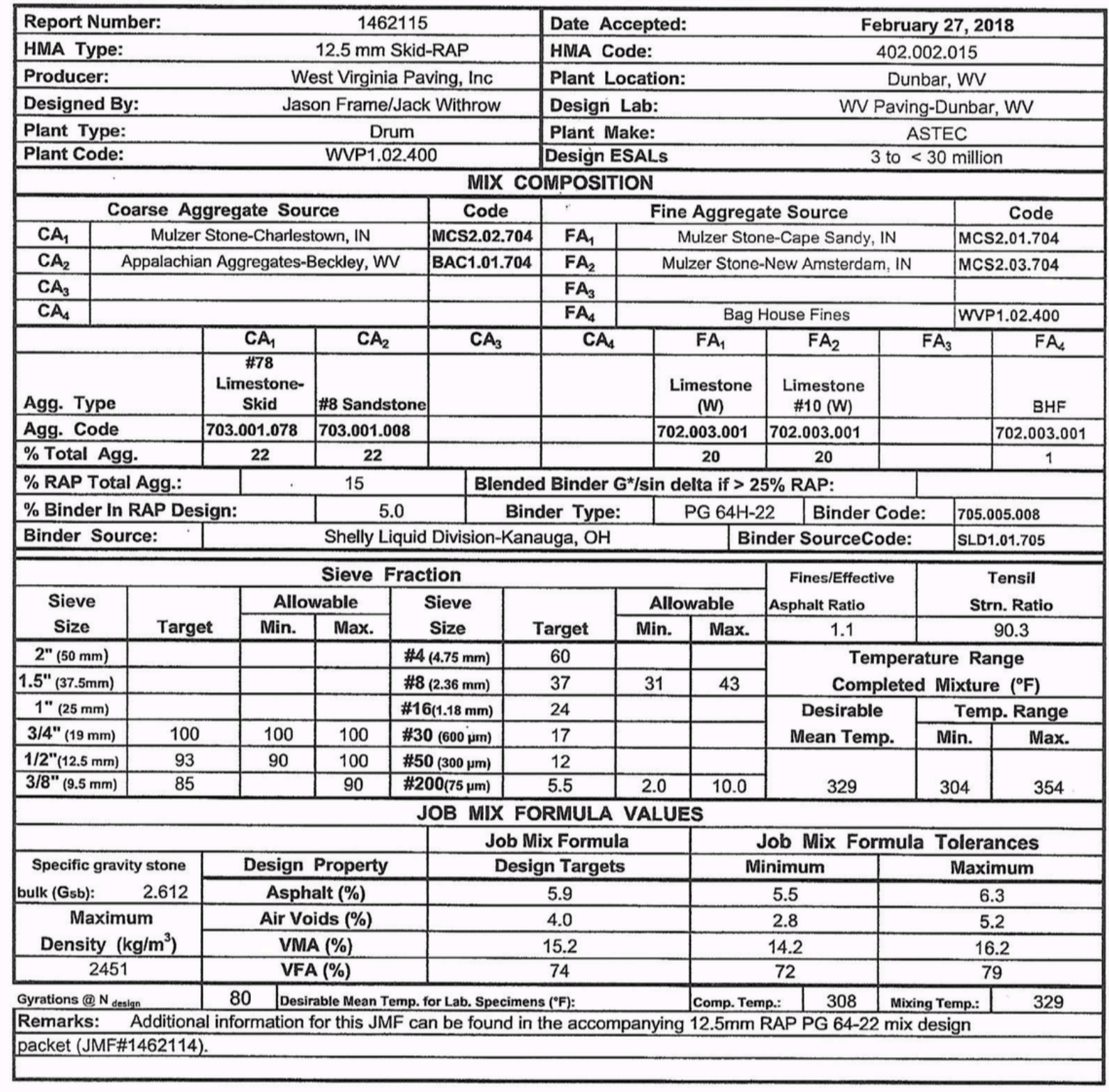

Figure 21: Job Mix Formula for West Virginia Paving, Inc. - $12.5 \mathrm{~mm}$ Skid-RAP 
WEST VIRGINIA DIVISION OF HIGHWAYS JOB MIX FORMULA FOR SUPERPAVE HOT-MIX ASPHALT

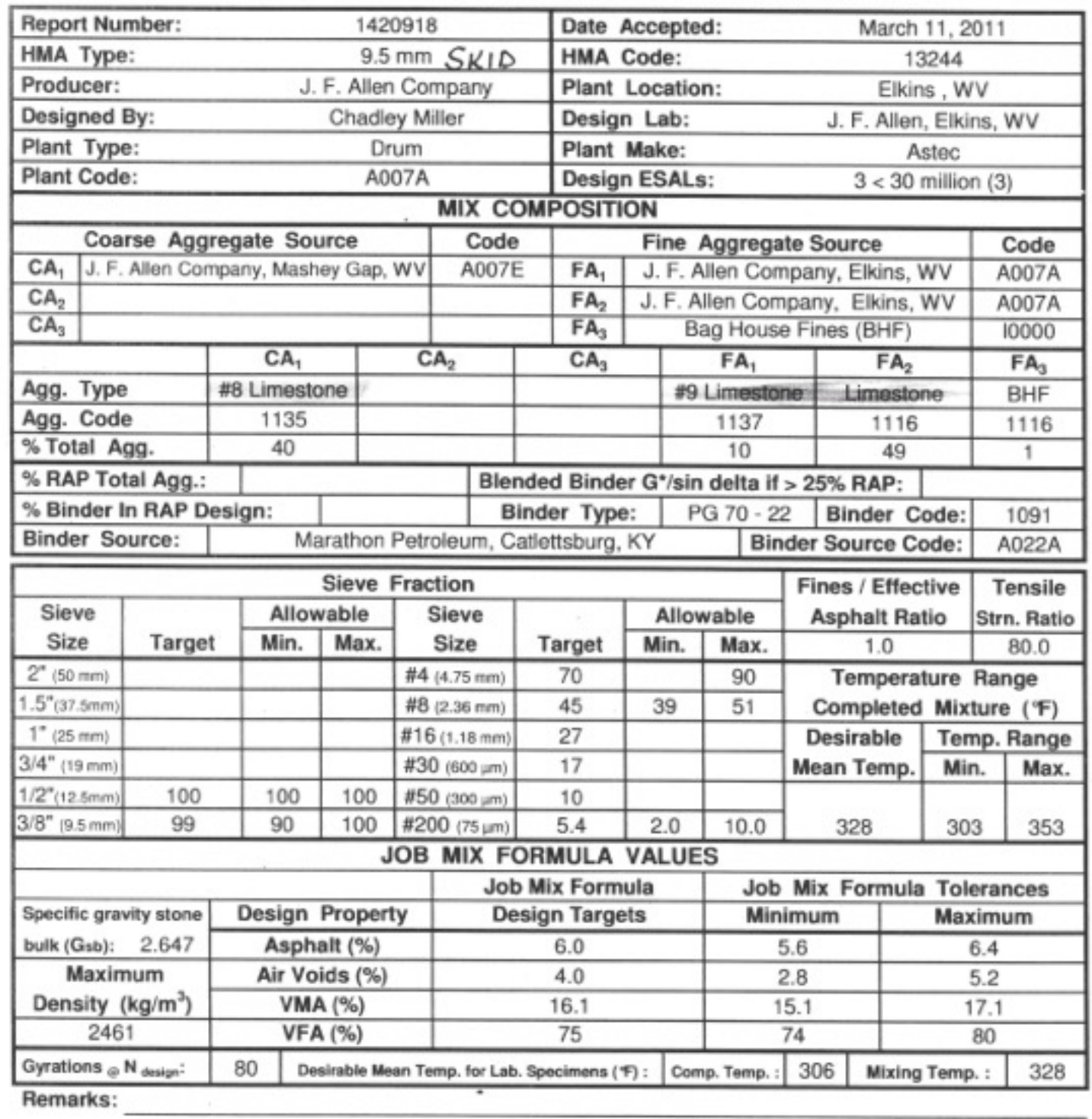

$\cos 40.6+24$

Figure 22: Job Mix Formula for J. F. Allen Co. - 9.5 mm SKID - Per Design Mixture 


\section{Batch Sheets}

DATE: $\quad$ 9/9/19

Project Number : $9.5 \mathrm{~mm}$ SUPERPAVE - WVU Skid Study

Aggr.1 = MASHEY GAP SKID 8'S

Aggr.2 = ELKINS 9'S

Aggr.3 = ELKINS SAND

MiX 4 Batches

Aggr. 4 = BAG HOUSE FINES

Aggr:5 =

\section{No Skid}

\begin{tabular}{|c|c|c|c|c|c|c|c|}
\hline & \multicolumn{7}{|c|}{ Mixture Testing Weights - Scale Weights } \\
\hline & \multirow{2}{*}{\multicolumn{2}{|c|}{$\begin{array}{c}\text { Batch weight }= \\
\% \text { Bin Splits => }\end{array}$}} & \multirow{4}{*}{$\begin{array}{c}9500.0 \\
40 \% \\
\text { MG } \\
8 ' S \\
\end{array}$} & \multicolumn{4}{|l|}{ grams } \\
\hline & & & & $10 \%$ & $49 \%$ & $1 \%$ & \\
\hline & \multicolumn{2}{|c|}{ Sieve Size } & & \multirow{2}{*}{$\begin{array}{l}\text { ELK } \\
\text { 9'S }\end{array}$} & \multirow{2}{*}{$\begin{array}{l}\text { ELK } \\
\text { SAND }\end{array}$} & \multirow[b]{2}{*}{ BHF } & \\
\hline & $\mathrm{mm}$ & US & & & & & \\
\hline & 50 & $2 "$ & & & & 5 & \\
\hline & 37.5 & $11 / 2 "$ & & & & 5 & \\
\hline & 25 & 1" & & & & (3) & \\
\hline 100.0 & 19 & $3 / 4 "$ & & & & 5.0 & \\
\hline 100.0 & 12.5 & $1 / 2 "$ & & & & 511 & \\
\hline 99.0 & 9.5 & $3 / 8^{\prime \prime}$ & 95.0 & & & $\sqrt{5.84}$ & \\
\hline 69.4 & 4.75 & $\# 4$ & 2705.9 & 4004.3 & & 0 & \\
\hline $\begin{array}{ll}44.8 \\
\end{array}$ & 2.36 & $\# 8$ & 3640.9 & 4659.0 & 5490.2 & (5) & \\
\hline 27.5 & 1.18 & $\# 16$ & 3705.8 & 4714.4 & 7022.1 & ज्ञात & \\
\hline 16.9 & 0.6 & $\# 30$ & 3728.8 & 4719.1 & 7999.8 & $5+1$ & \\
\hline 10.0 & 0.3 & \#50 & 3736.7 & 4719.9 & 8646.6 & 50 & \\
\hline 7.8 & 0.15 & $\# 100$ & 3744.6 & 4720.7 & 8846.9 & & \\
\hline \multirow[t]{3}{*}{5.3} & 0.075 & $\# 200$ & 3752.5 & 4724.7 & 9060.6 & 60.8 & \\
\hline & & Pan & 3800.0 & 4750.0 & 9405.0 & 9500.0 & \\
\hline & & Totals & 3800.0 & 950.0 & 4655.0 & 95.0 & 0.0 \\
\hline
\end{tabular}

\section{Asphalt Needed per batch}

\begin{tabular}{r|c|c|c|c|c|} 
Specimen $\#$ & 1 & 2 & 3 & 4 & 5 \\
\cline { 2 - 6 } Enter $\mathrm{Pb}$ & & & $5.7 \%$ & & \\
\cline { 2 - 5 } Mb needed & & & $\mathbf{5 7 4 . 2}$ & & \\
\cline { 2 - 6 }
\end{tabular}

Figure 23: Batch Sheet for J. F. Allen Co. -9.5 mm SKID - No Skid Mixture 


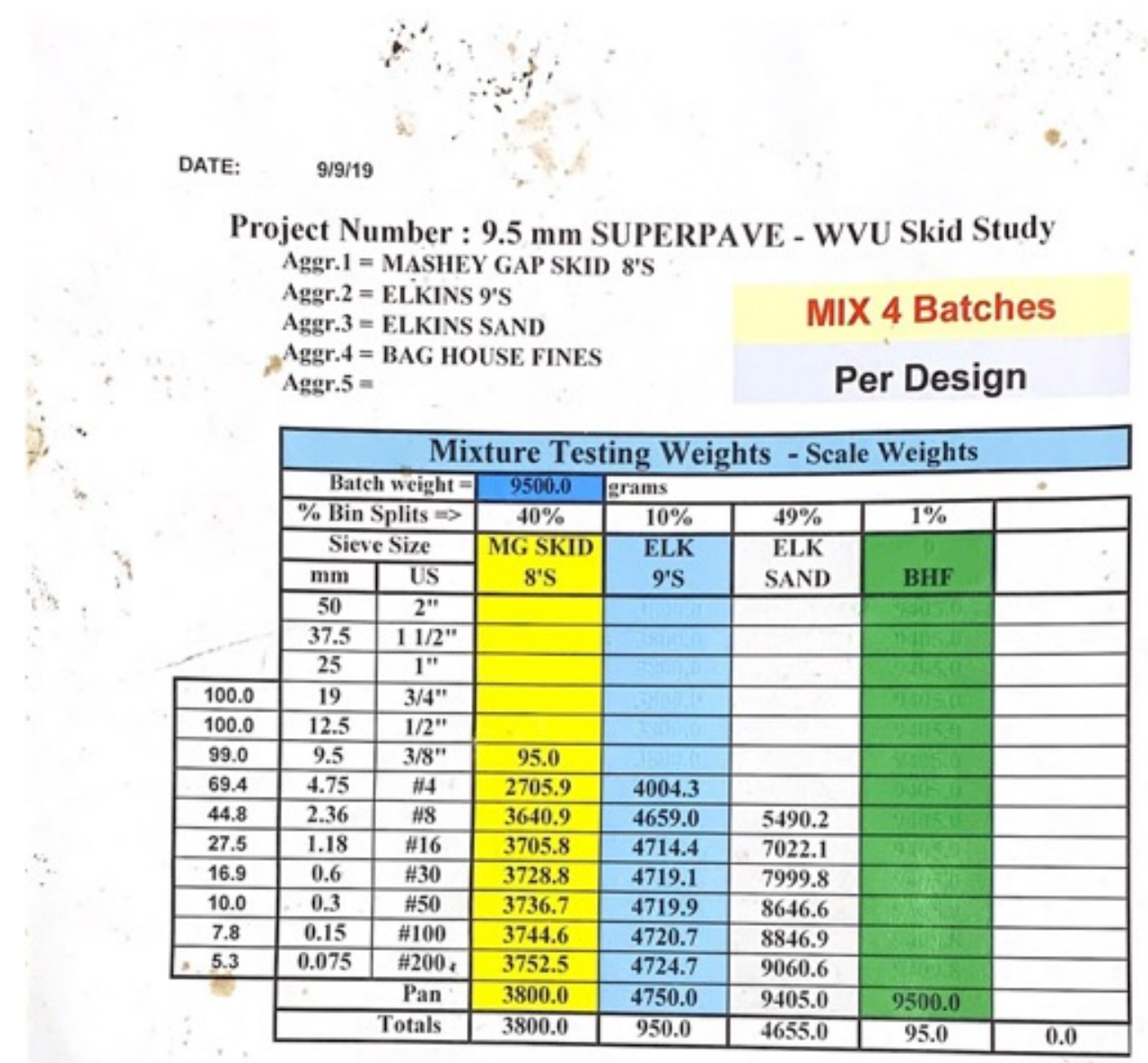

Asphalt Needed per batch

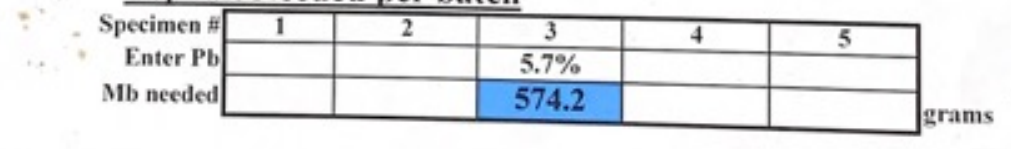

$\times 5.7 \div 94.3$

Figure 24: Batch Sheet for J. F. Allen Co. - $9.5 \mathrm{~mm}$ SKID - Per Design Mixture 
DATE: $\quad 9 / 9 / 19$

Project Number : $9.5 \mathrm{~mm}$ SUPERPAVE - WVU Skid Study Aggr.1 = MASHEY GAP SKID 8'S

Aggr.2 = EL.KINS 9'S

Aggr. $3=$ ELKINS SAND

MIX 4 Batches

Aggr.4 = BAG HOUSE FINES

Aggr.5 =

Opposite Skid

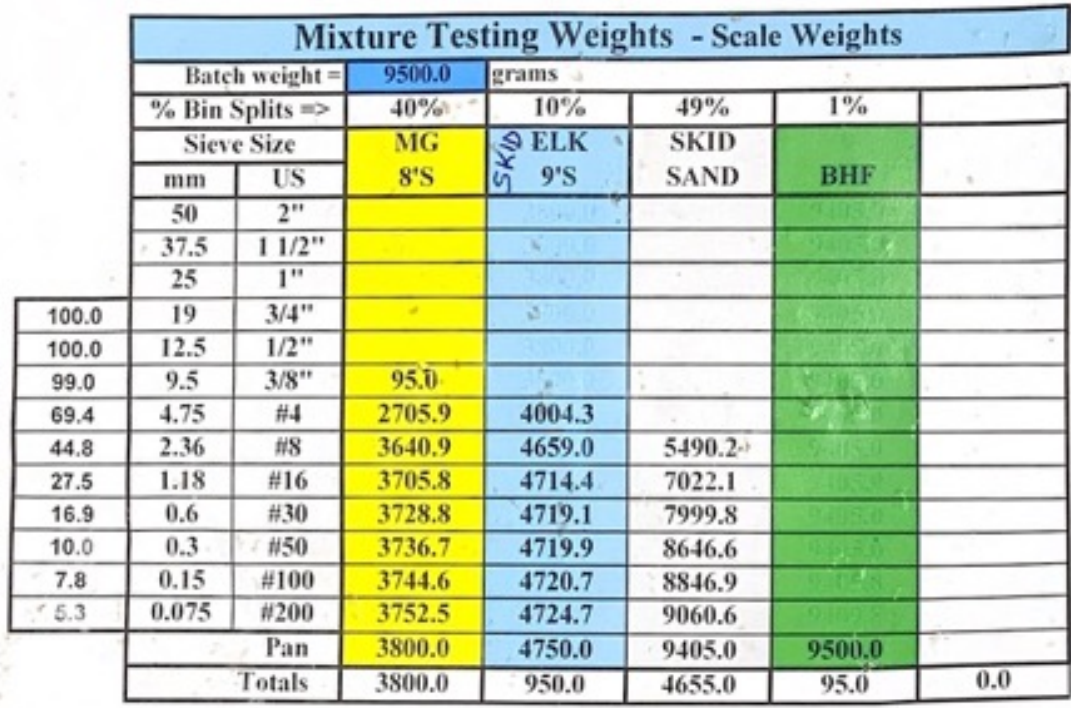

Asphalt Needed per batch

\begin{tabular}{r|c|c|c|c|c|}
\hline \begin{tabular}{r} 
Specimen $\#$ Enter $\mathrm{Pb}$ \\
\cline { 2 - 6 } Mb needed
\end{tabular} & 1 & 2 & 3 & 4 & 5 \\
\cline { 2 - 6 } & & & $5.7 \%$ & & \\
\cline { 2 - 6 } & & & 574.2 & & \\
\hline
\end{tabular}

Figure 25: Batch Sheet for J. F. Allen Co. -9.5 mm SKID - Opposite Skid Mixture 
DATE: $\quad 9 / 9 / 19$

Project Number : $9.5 \mathrm{~mm}$ SUPERPAVE - WVU Skid Study Aggr.1 = MASHEY GAP SKID 8'S

Aggr.2 = ELKINS 9'S

Aggr. $3=$ ELKINS SAND

Aggr.4 = BAG HOUSE FINES

Aggr.5 =

MIX 4 Batches

\section{All Skid}

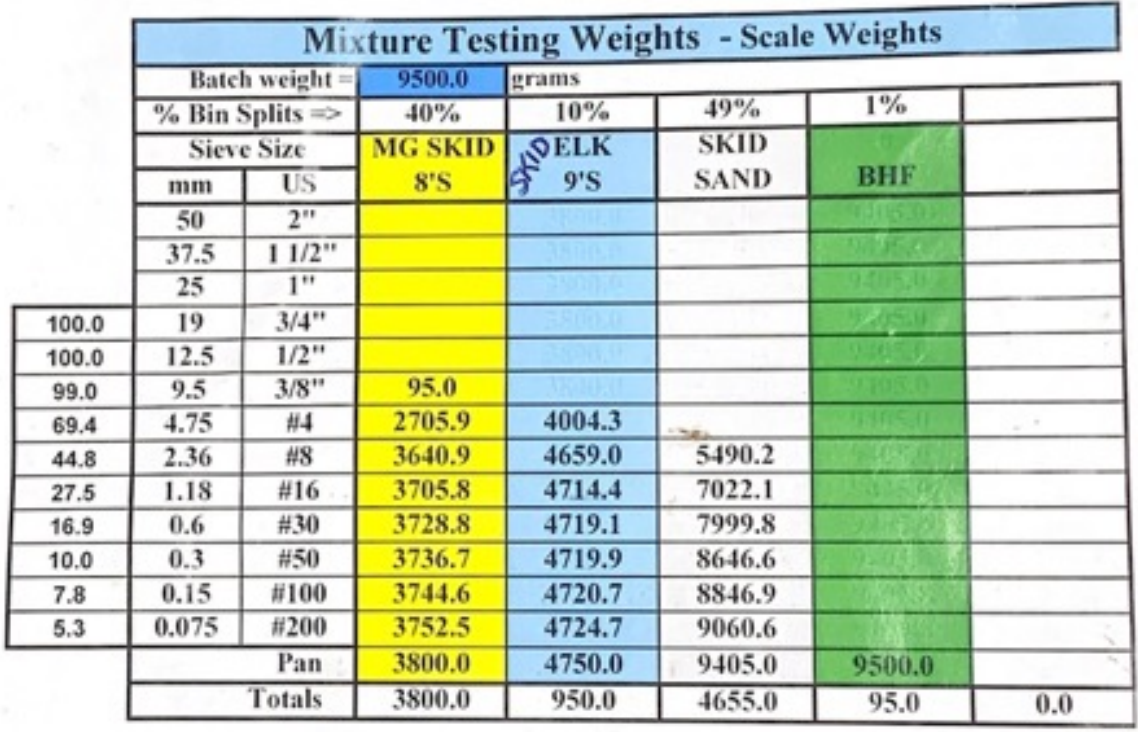

Asphalt Needed per batch

\begin{tabular}{|c|c|c|c|c|c|}
\hline \multirow{2}{*}{$\begin{array}{r}\text { Specimen } \# \\
\text { Enter } \mathrm{Pb}\end{array}$} & 1 & 2 & 3 & 4 & 5 \\
\hline & & ' & $5.7 \%$ & & \\
\hline Mb needed & & & 574.2 & & \\
\hline
\end{tabular}

Figure 26: Batch Sheet for J. F. Allen Co. -9.5 mm SKID - All Skid Mixture 


\section{Appendix B: Replicate Study Data}

Table 11: BPN data for Series 1 specimen

\begin{tabular}{|c|c|c|c|c|c|c|c|}
\hline Mix No. & $\begin{array}{c}\text { Mix } \\
\text { Name } \\
\end{array}$ & $\begin{array}{c}\text { Sample } \\
\text { Name }\end{array}$ & $\begin{array}{l}\text { Wheel } \\
\text { Passes }\end{array}$ & Trial 1 & Trial 2 & Trial 3 & Trial 4 \\
\hline \multirow[b]{3}{*}{1} & \multirow{3}{*}{$\begin{array}{c}\text { JF Allen } \\
12.5 \mathrm{~mm} \\
\text { SKID - } \\
4 \%\end{array}$} & S1 & 0 & 72 & 73 & 73 & 73 \\
\hline & & S2 & 0 & 71 & 70 & 70 & 69 \\
\hline & & S3 & 0 & 71 & 70 & 70 & 68 \\
\hline \multirow[b]{3}{*}{1} & \multirow{3}{*}{$\begin{array}{c}\text { JF Allen } \\
12.5 \mathrm{~mm} \\
\text { SKID - } \\
8 \% \\
\end{array}$} & S4 & 0 & 73 & 71 & 70 & 69 \\
\hline & & S5 & 0 & 68 & 67 & 67 & 68 \\
\hline & & S6 & 0 & 72 & 71 & 71 & 71 \\
\hline \multirow[b]{3}{*}{2} & \multirow{3}{*}{$\begin{array}{c}\text { WV Pav } \\
\text { W1-RAP } \\
-4 \% \\
\end{array}$} & S7 & 0 & 75 & 74 & 72 & 70 \\
\hline & & S8 & 0 & 75 & 74 & 73 & 73 \\
\hline & & S9 & 0 & 78 & 80 & 77 & 77 \\
\hline \multirow[b]{3}{*}{2} & \multirow{3}{*}{$\begin{array}{c}\text { WV Pav } \\
\text { W1-RAP } \\
-8 \%\end{array}$} & S10 & 0 & 78 & 78 & 78 & 78 \\
\hline & & $\mathrm{S} 12$ & 0 & 75 & 78 & 74 & 76 \\
\hline & & $\mathrm{S} 13$ & 0 & 77 & 76 & 74 & 74 \\
\hline \multirow[b]{3}{*}{1} & \multirow{3}{*}{$\begin{array}{c}\text { JF Allen } \\
12.5 \mathrm{~mm} \\
\text { SKID - } \\
4 \%\end{array}$} & S1 & 8,000 & 54 & 52 & 52 & 52 \\
\hline & & S2 & 8,000 & 55 & 54 & 53 & 52 \\
\hline & & S3 & 8,000 & 54 & 53 & 52 & 51 \\
\hline \multirow[b]{3}{*}{1} & \multirow{3}{*}{$\begin{array}{c}\text { JF Allen } \\
12.5 \mathrm{~mm} \\
\text { SKID - } \\
8 \%\end{array}$} & S4 & 8,000 & 55 & 53 & 54 & 52 \\
\hline & & S5 & 8,000 & 53 & 51 & 51 & 51 \\
\hline & & S6 & 8,000 & 55 & 55 & 54 & 53 \\
\hline \multirow[b]{3}{*}{2} & \multirow{3}{*}{$\begin{array}{c}\text { WV Pav } \\
\text { W1-RAP } \\
-4 \%\end{array}$} & S7 & 8,000 & 59 & 57 & 56 & 56 \\
\hline & & S8 & 8,000 & 57 & 56 & 55 & 54 \\
\hline & & S9 & 8,000 & 59 & 56 & 54 & 55 \\
\hline \multirow[b]{3}{*}{2} & \multirow{3}{*}{$\begin{array}{c}\text { WV Pav } \\
\text { W1-RAP } \\
-8 \%\end{array}$} & $\mathrm{~S} 10$ & 8,000 & 56 & 55 & 55 & 54 \\
\hline & & $\mathrm{S} 12$ & 8,000 & 54 & 55 & 54 & 53 \\
\hline & & $\mathrm{S} 13$ & 8,000 & 57 & 56 & 56 & 55 \\
\hline \multirow[b]{3}{*}{1} & \multirow{3}{*}{$\begin{array}{c}\text { JF Allen } \\
12.5 \mathrm{~mm} \\
\text { SKID - } \\
4 \% \\
\end{array}$} & S1 & 16,000 & 46 & 47 & 45 & 43 \\
\hline & & $\mathrm{S} 2$ & 16,000 & 47 & 46 & 46 & 44 \\
\hline & & S3 & 16,000 & 48 & 46 & 44 & 45 \\
\hline \multirow[b]{3}{*}{1} & \multirow{3}{*}{$\begin{array}{c}\text { JF Allen } \\
12.5 \mathrm{~mm} \\
\text { SKID - } \\
8 \%\end{array}$} & S4 & 16,000 & 48 & 47 & 47 & 47 \\
\hline & & S5 & 16,000 & 48 & 48 & 47 & 47 \\
\hline & & S6 & 16,000 & 47 & 47 & 47 & 46 \\
\hline \multirow[b]{2}{*}{2} & & S7 & 16,000 & 52 & 48 & 51 & 50 \\
\hline & & S8 & 16,000 & 52 & 51 & 50 & 49 \\
\hline
\end{tabular}




\begin{tabular}{|c|c|c|c|c|c|c|c|}
\hline & $\begin{array}{c}\text { WV Pav } \\
\text { W1-RAP } \\
-4 \%\end{array}$ & S9 & 16,000 & 52 & 50 & 50 & 50 \\
\hline \multirow[b]{3}{*}{2} & \multirow{3}{*}{$\begin{array}{c}\text { WV Pav } \\
\text { W1-RAP } \\
-8 \%\end{array}$} & $\mathrm{~S} 10$ & 16,000 & 55 & 54 & 53 & 52 \\
\hline & & $\mathrm{S} 12$ & 16,000 & 54 & 53 & 51 & 47 \\
\hline & & $\mathrm{S} 13$ & 16,000 & 56 & 54 & 52 & 52 \\
\hline \multirow[b]{3}{*}{1} & \multirow{3}{*}{$\begin{array}{c}\text { JF Allen } \\
12.5 \mathrm{~mm} \\
\text { SKID - } \\
4 \%\end{array}$} & S1 & 32,000 & 43 & 42 & 41 & 41 \\
\hline & & $\mathrm{S} 2$ & 32,000 & 45 & 44 & 43 & 42 \\
\hline & & $\mathrm{S} 3$ & 32,000 & 45 & 44 & 42 & 42 \\
\hline \multirow[b]{3}{*}{1} & \multirow{3}{*}{$\begin{array}{c}\text { JF Allen } \\
12.5 \mathrm{~mm} \\
\text { SKID - } \\
8 \% \\
\end{array}$} & $\mathrm{~S} 4$ & 32,000 & 46 & 45 & 44 & 43 \\
\hline & & S5 & 32,000 & 45 & 44 & 43 & 43 \\
\hline & & S6 & 32,000 & 46 & 43 & 44 & 42 \\
\hline \multirow[b]{3}{*}{2} & \multirow{3}{*}{$\begin{array}{c}\text { WV Pav } \\
\text { W1-RAP } \\
-4 \%\end{array}$} & S7 & 32,000 & 47 & 45 & 45 & 45 \\
\hline & & S8 & 32,000 & 48 & 47 & 46 & 46 \\
\hline & & S9 & 32,000 & 47 & 47 & 46 & 45 \\
\hline \multirow[b]{3}{*}{2} & \multirow{3}{*}{$\begin{array}{c}\text { WV Pav } \\
\text { W1-RAP } \\
-8 \%\end{array}$} & $\mathrm{~S} 10$ & 32,000 & 47 & 47 & 46 & 46 \\
\hline & & $\mathrm{S} 12$ & 32,000 & 50 & 47 & 46 & 46 \\
\hline & & $\mathrm{S} 13$ & 32,000 & 49 & 48 & 47 & 46 \\
\hline \multirow[b]{3}{*}{1} & \multirow{3}{*}{$\begin{array}{c}\text { JF Allen } \\
12.5 \mathrm{~mm} \\
\text { SKID - } \\
4 \%\end{array}$} & $\mathrm{~S} 1$ & 48,000 & 43 & 42 & 41 & 40 \\
\hline & & $\mathrm{S} 2$ & 48,000 & 42 & 40 & 38 & 39 \\
\hline & & $\mathrm{S} 3$ & 48,000 & 43 & 42 & 41 & 41 \\
\hline \multirow[b]{3}{*}{1} & \multirow{3}{*}{$\begin{array}{c}\text { JF Allen } \\
12.5 \mathrm{~mm} \\
\text { SKID - } \\
8 \%\end{array}$} & $\mathrm{~S} 4$ & 48,000 & 42 & 40 & 40 & 39 \\
\hline & & S5 & 48,000 & 41 & 39 & 38 & 38 \\
\hline & & S6 & 48,000 & 43 & 42 & 40 & 40 \\
\hline \multirow[b]{3}{*}{2} & \multirow{3}{*}{$\begin{array}{c}\text { WV Pav } \\
\text { W1-RAP } \\
-4 \% \\
\end{array}$} & S7 & 48,000 & 46 & 45 & 44 & 44 \\
\hline & & S8 & 48,000 & 45 & 44 & 43 & 42 \\
\hline & & S9 & 48,000 & 44 & 43 & 42 & 41 \\
\hline \multirow[b]{3}{*}{2} & \multirow{3}{*}{$\begin{array}{l}\text { WV Pav } \\
\text { W1-RAP } \\
-8 \%\end{array}$} & $\mathrm{~S} 10$ & 48,000 & 45 & 43 & 42 & 42 \\
\hline & & $\mathrm{S} 12$ & 48,000 & 44 & 43 & 43 & 42 \\
\hline & & $\mathrm{S} 13$ & 48,000 & 45 & 44 & 44 & 42 \\
\hline
\end{tabular}


Table 12: BPN data for Series 2 specimen

\begin{tabular}{|c|c|c|c|c|c|c|c|}
\hline Mix No. & $\begin{array}{c}\text { Mix } \\
\text { Name }\end{array}$ & $\begin{array}{c}\text { Sample } \\
\text { Name }\end{array}$ & Wheel Passes & Trial 1 & Trial 2 & Trial 3 & Trial 4 \\
\hline \multirow[b]{3}{*}{1} & \multirow{3}{*}{$\begin{array}{c}\text { JF Allen } \\
12.5 \mathrm{~mm} \\
\text { SKID - } \\
4 \%\end{array}$} & $\mathrm{~S} 1$ & 0 & 64 & 62 & 62 & 61 \\
\hline & & $\mathrm{S} 2$ & 0 & 67 & 64 & 63 & 62 \\
\hline & & S3 & 0 & 66 & 64 & 63 & 62 \\
\hline \multirow[b]{3}{*}{1} & \multirow{3}{*}{$\begin{array}{c}\text { JF Allen } \\
12.5 \mathrm{~mm} \\
\text { SKID - } \\
8 \% \\
\end{array}$} & S4 & 0 & 64 & 63 & 62 & 61 \\
\hline & & S5 & 0 & 64 & 62 & 61 & 61 \\
\hline & & S6 & 0 & 68 & 66 & 66 & 66 \\
\hline \multirow[b]{3}{*}{2} & \multirow{3}{*}{$\begin{array}{c}\text { WV Pav } \\
\text { W1-RAP } \\
-4 \%\end{array}$} & S7 & 0 & 71 & 70 & 70 & 69 \\
\hline & & S8 & 0 & 69 & 69 & 69 & 67 \\
\hline & & S9 & 0 & 73 & 73 & 73 & 73 \\
\hline \multirow[b]{3}{*}{2} & \multirow{3}{*}{$\begin{array}{c}\text { WV Pav } \\
\text { W1-RAP } \\
-8 \%\end{array}$} & S10 & 0 & 71 & 69 & 69 & 68 \\
\hline & & $\mathrm{S} 12$ & 0 & 74 & 74 & 73 & 72 \\
\hline & & $\mathrm{S} 13$ & 0 & 71 & 71 & 69 & 68 \\
\hline \multirow[b]{3}{*}{1} & \multirow{3}{*}{$\begin{array}{c}\text { JF Allen } \\
12.5 \mathrm{~mm} \\
\text { SKID - } \\
4 \%\end{array}$} & S1 & 8,000 & 51 & 50 & 49 & 48 \\
\hline & & $\mathrm{S} 2$ & 8,000 & 51 & 50 & 49 & 49 \\
\hline & & S3 & 8,000 & 51 & 50 & 50 & 49 \\
\hline \multirow[b]{3}{*}{1} & \multirow{3}{*}{$\begin{array}{c}\text { JF Allen } \\
12.5 \mathrm{~mm} \\
\text { SKID - } \\
8 \% \\
\end{array}$} & S4 & 8,000 & 53 & 51 & 50 & 49 \\
\hline & & S5 & 8,000 & 54 & 52 & 52 & 51 \\
\hline & & S6 & 8,000 & 52 & 51 & 51 & 50 \\
\hline \multirow[b]{3}{*}{2} & \multirow{3}{*}{$\begin{array}{c}\text { WV Pav } \\
\text { W1-RAP } \\
-4 \% \\
\end{array}$} & S7 & 8,000 & 54 & 54 & 53 & 53 \\
\hline & & $\mathrm{S} 8$ & 8,000 & 57 & 56 & 54 & 54 \\
\hline & & S9 & 8,000 & 55 & 55 & 54 & 53 \\
\hline \multirow[b]{3}{*}{2} & \multirow{3}{*}{$\begin{array}{c}\text { WV Pav } \\
\text { W1-RAP } \\
-8 \%\end{array}$} & S10 & 8,000 & 58 & 57 & 55 & 54 \\
\hline & & $\mathrm{S} 12$ & 8,000 & 58 & 57 & 56 & 55 \\
\hline & & $\mathrm{S} 13$ & 8,000 & 56 & 54 & 54 & 54 \\
\hline \multirow[b]{3}{*}{1} & \multirow{3}{*}{$\begin{array}{c}\text { JF Allen } \\
12.5 \mathrm{~mm} \\
\text { SKID - } \\
4 \%\end{array}$} & S1 & 16,000 & 45 & 43 & 43 & 43 \\
\hline & & $\mathrm{S} 2$ & 16,000 & 46 & 46 & 45 & 44 \\
\hline & & S3 & 16,000 & 47 & 46 & 44 & 44 \\
\hline \multirow[b]{3}{*}{1} & \multirow{3}{*}{$\begin{array}{c}\text { JF Allen } \\
12.5 \mathrm{~mm} \\
\text { SKID - } \\
8 \% \\
\end{array}$} & S4 & 16,000 & 47 & 46 & 45 & 45 \\
\hline & & S5 & 16,000 & 47 & 46 & 45 & 45 \\
\hline & & S6 & 16,000 & 47 & 45 & 45 & 44 \\
\hline \multirow[b]{3}{*}{2} & \multirow{4}{*}{$\begin{array}{c}\text { WV Pav } \\
\text { W1-RAP } \\
-4 \% \\
\end{array}$} & S7 & 16,000 & 52 & 50 & 49 & 49 \\
\hline & & S8 & 16,000 & 52 & 50 & 50 & 49 \\
\hline & & S9 & 16,000 & 51 & 49 & 49 & 48 \\
\hline 2 & & $\mathrm{~S} 10$ & 16,000 & 52 & 50 & 50 & 50 \\
\hline
\end{tabular}




\begin{tabular}{|c|c|c|c|c|c|c|c|}
\hline & WV Pav & $\mathrm{S} 12$ & 16,000 & 53 & 51 & 50 & 50 \\
\hline & $-8 \%$ & $\mathrm{~S} 13$ & 16,000 & 53 & 52 & 51 & 49 \\
\hline \multirow[b]{3}{*}{1} & \multirow{3}{*}{$\begin{array}{c}\text { JF Allen } \\
12.5 \mathrm{~mm} \\
\text { SKID - } \\
4 \% \\
\end{array}$} & $\mathrm{~S} 1$ & 32,000 & 42 & 41 & 41 & 41 \\
\hline & & $\mathrm{S} 2$ & 32,000 & 43 & 42 & 42 & 41 \\
\hline & & $\mathrm{S} 3$ & 32,000 & 44 & 42 & 41 & 41 \\
\hline \multirow[b]{3}{*}{1} & \multirow{3}{*}{$\begin{array}{c}\text { JF Allen } \\
12.5 \mathrm{~mm} \\
\text { SKID - } \\
8 \% \\
\end{array}$} & $\mathrm{~S} 4$ & 32,000 & 43 & 41 & 41 & 41 \\
\hline & & S5 & 32,000 & 45 & 44 & 43 & 42 \\
\hline & & S6 & 32,000 & 44 & 43 & 43 & 43 \\
\hline \multirow[b]{3}{*}{2} & \multirow{3}{*}{$\begin{array}{c}\text { WV Pav } \\
\text { W1-RAP } \\
-4 \%\end{array}$} & S7 & 32,000 & 47 & 47 & 47 & 46 \\
\hline & & S8 & 32,000 & 49 & 48 & 47 & 47 \\
\hline & & S9 & 32,000 & 48 & 47 & 47 & 46 \\
\hline \multirow[b]{3}{*}{2} & \multirow{3}{*}{$\begin{array}{c}\text { WV Pav } \\
\text { W1-RAP } \\
-8 \%\end{array}$} & $\mathrm{~S} 10$ & 32,000 & 48 & 47 & 46 & 46 \\
\hline & & $\mathrm{S} 12$ & 32,000 & 50 & 48 & 47 & 46 \\
\hline & & $\mathrm{S} 13$ & 32,000 & 49 & 48 & 47 & 47 \\
\hline \multirow[b]{3}{*}{1} & \multirow{3}{*}{$\begin{array}{c}\text { JF Allen } \\
12.5 \mathrm{~mm} \\
\text { SKID - } \\
4 \%\end{array}$} & S1 & 48,000 & 40 & 38 & 38 & 38 \\
\hline & & $\mathrm{S} 2$ & 48,000 & 39 & 38 & 37 & 37 \\
\hline & & $\mathrm{S} 3$ & 48,000 & 39 & 39 & 39 & 38 \\
\hline \multirow[b]{3}{*}{1} & \multirow{3}{*}{$\begin{array}{c}\text { JF Allen } \\
12.5 \mathrm{~mm} \\
\text { SKID - } \\
8 \% \\
\end{array}$} & $\mathrm{~S} 4$ & 48,000 & 41 & 39 & 39 & 38 \\
\hline & & S5 & 48,000 & 41 & 39 & 39 & 39 \\
\hline & & S6 & 48,000 & 40 & 39 & 39 & 39 \\
\hline \multirow[b]{3}{*}{2} & \multirow{3}{*}{$\begin{array}{c}\text { WV Pav } \\
\text { W1-RAP } \\
-4 \%\end{array}$} & S7 & 48,000 & 44 & 42 & 43 & 41 \\
\hline & & S8 & 48,000 & 45 & 45 & 44 & 44 \\
\hline & & S9 & 48,000 & 45 & 44 & 44 & 43 \\
\hline \multirow[b]{3}{*}{2} & \multirow{3}{*}{$\begin{array}{c}\text { WV Pav } \\
\text { W1-RAP } \\
-8 \%\end{array}$} & $\mathrm{~S} 10$ & 48,000 & 45 & 44 & 43 & 43 \\
\hline & & $\mathrm{S} 12$ & 48,000 & 44 & 44 & 42 & 42 \\
\hline & & $\mathrm{S} 13$ & 48,000 & 45 & 44 & 42 & 43 \\
\hline
\end{tabular}


Table 13: BPN data for Series 3 specimen

\begin{tabular}{|c|c|c|c|c|c|c|c|}
\hline Mix No. & $\begin{array}{c}\text { Mix } \\
\text { Name } \\
\end{array}$ & $\begin{array}{c}\text { Sample } \\
\text { Name }\end{array}$ & $\begin{array}{l}\text { Wheel } \\
\text { Passes } \\
\end{array}$ & Trial 1 & Trial 2 & Trial 3 & Trial 4 \\
\hline \multirow[b]{3}{*}{3} & \multirow{3}{*}{$\begin{array}{c}\text { Greer } \\
\text { W1H - } \\
4 \% \\
\end{array}$} & S16 & 0 & 67 & 68 & 68 & 68 \\
\hline & & S26 & 0 & 66 & 66 & 67 & 67 \\
\hline & & S27 & 0 & 64 & 65 & 65 & 66 \\
\hline \multirow[b]{3}{*}{3} & \multirow{3}{*}{$\begin{array}{c}\text { Greer } \\
\text { W1H - } \\
8 \% \\
\end{array}$} & S29 & 0 & 65 & 65 & 66 & 66 \\
\hline & & S30 & 0 & 66 & 68 & 68 & 68 \\
\hline & & S31 & 0 & 67 & 67 & 68 & 67 \\
\hline \multirow[b]{3}{*}{4} & \multirow{3}{*}{$\begin{array}{c}\text { WV Pav } \\
12.5 \mathrm{~mm} \\
\text { SKID - } \\
4 \%\end{array}$} & $\mathrm{~S} 20$ & 0 & 65 & 65 & 65 & 64 \\
\hline & & $\mathrm{S} 21$ & 0 & 63 & 64 & 64 & 64 \\
\hline & & S22 & 0 & 60 & 60 & 61 & 61 \\
\hline \multirow[b]{3}{*}{4} & \multirow{3}{*}{$\begin{array}{c}\text { WV Pav } \\
12.5 \mathrm{~mm} \\
\text { SKID - } \\
8 \% \\
\end{array}$} & $\mathrm{~S} 23$ & 0 & 64 & 65 & 65 & 66 \\
\hline & & S25 & 0 & 62 & 62 & 62 & 63 \\
\hline & & $\mathrm{S} 32$ & 0 & 61 & 61 & 62 & 63 \\
\hline \multirow[b]{3}{*}{3} & \multirow{3}{*}{$\begin{array}{c}\text { Greer } \\
\text { W1H - } \\
4 \% \\
\end{array}$} & S16 & 8,000 & 55 & 55 & 53 & 52 \\
\hline & & S26 & 8,000 & 54 & 54 & 54 & 53 \\
\hline & & S27 & 8,000 & 55 & 54 & 53 & 52 \\
\hline \multirow[b]{3}{*}{3} & \multirow{3}{*}{$\begin{array}{c}\text { Greer } \\
\text { W1H - } \\
8 \% \\
\end{array}$} & S29 & 8,000 & 53 & 53 & 52 & 51 \\
\hline & & S30 & 8,000 & 53 & 53 & 52 & 53 \\
\hline & & S31 & 8,000 & 55 & 54 & 52 & 51 \\
\hline \multirow[b]{3}{*}{4} & \multirow{3}{*}{$\begin{array}{c}\text { WV Pav } \\
12.5 \mathrm{~mm} \\
\text { SKID - } \\
4 \%\end{array}$} & $\mathrm{~S} 20$ & 8,000 & 55 & 54 & 53 & 52 \\
\hline & & S21 & 8,000 & 54 & 53 & 53 & 52 \\
\hline & & $\mathrm{S} 22$ & 8,000 & 54 & 53 & 53 & 52 \\
\hline \multirow[b]{3}{*}{4} & \multirow{3}{*}{$\begin{array}{c}\text { WV Pav } \\
12.5 \mathrm{~mm} \\
\text { SKID - } \\
8 \% \\
\end{array}$} & $\mathrm{~S} 23$ & 8,000 & 55 & 54 & 54 & 53 \\
\hline & & $\mathrm{S} 25$ & 8,000 & 54 & 54 & 53 & 53 \\
\hline & & S32 & 8,000 & 55 & 54 & 53 & 53 \\
\hline \multirow[b]{3}{*}{3} & \multirow{3}{*}{$\begin{array}{c}\text { Greer } \\
\text { W1H - } \\
4 \% \\
\end{array}$} & S16 & 16,000 & 49 & 48 & 47 & 47 \\
\hline & & S26 & 16,000 & 48 & 46 & 46 & 46 \\
\hline & & S27 & 16,000 & 48 & 47 & 47 & 47 \\
\hline \multirow[b]{3}{*}{3} & \multirow{3}{*}{$\begin{array}{c}\text { Greer } \\
\text { W1H - } \\
8 \%\end{array}$} & S29 & 16,000 & 48 & 47 & 47 & 46 \\
\hline & & S30 & 16,000 & 48 & 47 & 46 & 46 \\
\hline & & S31 & 16,000 & 49 & 47 & 46 & 47 \\
\hline \multirow[b]{3}{*}{4} & \multirow{3}{*}{$\begin{array}{c}\text { WV Pav } \\
12.5 \mathrm{~mm} \\
\text { SKID - } \\
4 \% \\
\end{array}$} & S20 & 16,000 & 48 & 47 & 47 & 46 \\
\hline & & S21 & 16,000 & 50 & 49 & 49 & 48 \\
\hline & & S22 & 16,000 & 49 & 47 & 48 & 47 \\
\hline 4 & & $\mathrm{~S} 23$ & 16,000 & 52 & 51 & 49 & 49 \\
\hline
\end{tabular}




\begin{tabular}{|c|c|c|c|c|c|c|c|}
\hline & WV Pav & $\mathrm{S} 25$ & 16,000 & 51 & 49 & 48 & 48 \\
\hline & $\begin{array}{c}\text { SKID - } \\
8 \%\end{array}$ & S32 & 16,000 & 51 & 51 & 50 & 49 \\
\hline \multirow[b]{3}{*}{3} & \multirow{3}{*}{$\begin{array}{c}\text { Greer } \\
\mathrm{W} 1 \mathrm{H}- \\
4 \% \\
\end{array}$} & S16 & 32,000 & 46 & 44 & 44 & 43 \\
\hline & & S26 & 32,000 & 46 & 45 & 43 & 43 \\
\hline & & $\mathrm{S} 27$ & 32,000 & 45 & 44 & 44 & 43 \\
\hline \multirow[b]{3}{*}{3} & \multirow{3}{*}{$\begin{array}{c}\text { Greer } \\
\text { W1H - } \\
8 \%\end{array}$} & $\mathrm{~S} 29$ & 32,000 & 46 & 44 & 43 & 43 \\
\hline & & $\mathrm{S} 30$ & 32,000 & 47 & 46 & 45 & 45 \\
\hline & & S31 & 32,000 & 45 & 43 & 43 & 43 \\
\hline \multirow[b]{3}{*}{4} & \multirow{3}{*}{$\begin{array}{c}\text { WV Pav } \\
12.5 \mathrm{~mm} \\
\text { SKID - } \\
4 \%\end{array}$} & $\mathrm{~S} 20$ & 32,000 & 46 & 45 & 44 & 44 \\
\hline & & S21 & 32,000 & 46 & 45 & 44 & 44 \\
\hline & & $\mathrm{S} 22$ & 32,000 & 45 & 44 & 44 & 44 \\
\hline \multirow[b]{3}{*}{4} & \multirow{3}{*}{$\begin{array}{c}\text { WV Pav } \\
12.5 \mathrm{~mm} \\
\text { SKID - } \\
8 \%\end{array}$} & $\mathrm{~S} 23$ & 32,000 & 47 & 46 & 45 & 45 \\
\hline & & $\mathrm{S} 25$ & 32,000 & 47 & 45 & 45 & 44 \\
\hline & & S32 & 32,000 & 46 & 46 & 45 & 44 \\
\hline \multirow[b]{3}{*}{3} & \multirow{3}{*}{$\begin{array}{c}\text { Greer } \\
\mathrm{W} 1 \mathrm{H}- \\
4 \% \\
\end{array}$} & $\mathrm{~S} 16$ & 48,000 & 41 & 40 & 39 & 38 \\
\hline & & S26 & 48,000 & 41 & 40 & 39 & 38 \\
\hline & & $\mathrm{S} 27$ & 48,000 & 41 & 39 & 38 & 38 \\
\hline \multirow[b]{3}{*}{3} & \multirow{3}{*}{$\begin{array}{c}\text { Greer } \\
\text { W1H - } \\
8 \%\end{array}$} & S29 & 48,000 & 40 & 38 & 38 & 36 \\
\hline & & $\mathrm{S} 30$ & 48,000 & 42 & 39 & 38 & 38 \\
\hline & & S31 & 48,000 & 42 & 39 & 38 & 38 \\
\hline \multirow[b]{3}{*}{4} & \multirow{3}{*}{$\begin{array}{c}\text { WV Pav } \\
12.5 \mathrm{~mm} \\
\text { SKID - } \\
4 \%\end{array}$} & $\mathrm{~S} 20$ & 48,000 & 42 & 41 & 39 & 38 \\
\hline & & $\mathrm{S} 21$ & 48,000 & 42 & 40 & 39 & 39 \\
\hline & & $\mathrm{S} 22$ & 48,000 & 42 & 39 & 38 & 38 \\
\hline \multirow[b]{3}{*}{4} & \multirow{3}{*}{$\begin{array}{c}\text { WV Pav } \\
12.5 \mathrm{~mm} \\
\text { SKID - } \\
8 \%\end{array}$} & $\mathrm{~S} 23$ & 48,000 & 43 & 41 & 40 & 39 \\
\hline & & $\mathrm{S} 25$ & 48,000 & 41 & 39 & 37 & 37 \\
\hline & & S32 & 48,000 & 42 & 41 & 40 & 39 \\
\hline
\end{tabular}


Table 14: BPN data for Series 4 specimen

\begin{tabular}{|c|c|c|c|c|c|c|c|}
\hline Mix No. & $\begin{array}{c}\text { Mix } \\
\text { Name } \\
\end{array}$ & $\begin{array}{c}\text { Sample } \\
\text { Name }\end{array}$ & $\begin{array}{l}\text { Wheel } \\
\text { Passes } \\
\end{array}$ & Trial 1 & Trial 2 & Trial 3 & Trial 4 \\
\hline \multirow[b]{3}{*}{3} & \multirow{3}{*}{$\begin{array}{c}\text { Greer } \\
\mathrm{W} 1 \mathrm{H}- \\
4 \%\end{array}$} & S16 & 0 & 67 & 67 & 67 & 66 \\
\hline & & S26 & 0 & 71 & 70 & 70 & 70 \\
\hline & & S27 & 0 & 72 & 71 & 71 & 70 \\
\hline \multirow[b]{3}{*}{3} & \multirow{3}{*}{$\begin{array}{c}\text { Greer } \\
\mathrm{W} 1 \mathrm{H}- \\
8 \%\end{array}$} & S29 & 0 & 73 & 74 & 74 & 72 \\
\hline & & S30 & 0 & 71 & 70 & 69 & 68 \\
\hline & & S31 & 0 & 72 & 71 & 69 & 69 \\
\hline \multirow[b]{3}{*}{4} & \multirow{3}{*}{$\begin{array}{c}\text { WV Pav } \\
12.5 \mathrm{~mm} \\
\text { SKID - } \\
4 \% \\
\end{array}$} & S20 & 0 & 72 & 70 & 70 & 69 \\
\hline & & $\mathrm{S} 21$ & 0 & 72 & 71 & 71 & 71 \\
\hline & & $\mathrm{S} 22$ & 0 & 72 & 71 & 71 & 70 \\
\hline \multirow[b]{3}{*}{4} & \multirow{3}{*}{$\begin{array}{c}\text { WV Pav } \\
12.5 \mathrm{~mm} \\
\text { SKID - } \\
8 \% \\
\end{array}$} & $\mathrm{~S} 23$ & 0 & 73 & 73 & 74 & 72 \\
\hline & & S25 & 0 & 73 & 71 & 71 & 70 \\
\hline & & $\mathrm{S} 32$ & 0 & 73 & 73 & 73 & 72 \\
\hline \multirow[b]{3}{*}{3} & \multirow{3}{*}{$\begin{array}{c}\text { Greer } \\
\mathrm{W} 1 \mathrm{H}- \\
4 \%\end{array}$} & S16 & 8,000 & 51 & 49 & 48 & 48 \\
\hline & & S26 & 8,000 & 49 & 49 & 49 & 48 \\
\hline & & S27 & 8,000 & 51 & 50 & 50 & 50 \\
\hline \multirow[b]{3}{*}{3} & \multirow{3}{*}{$\begin{array}{c}\text { Greer } \\
\text { W1H - } \\
8 \%\end{array}$} & $\mathrm{~S} 29$ & 8,000 & 51 & 50 & 50 & 50 \\
\hline & & $\mathrm{S} 30$ & 8,000 & 52 & 51 & 51 & 50 \\
\hline & & $\mathrm{S} 31$ & 8,000 & 52 & 51 & 50 & 50 \\
\hline \multirow[b]{3}{*}{4} & \multirow{3}{*}{$\begin{array}{c}\text { WV Pav } \\
12.5 \mathrm{~mm} \\
\text { SKID - } \\
4 \%\end{array}$} & $\mathrm{~S} 20$ & 8,000 & 53 & 51 & 51 & 50 \\
\hline & & $\mathrm{S} 21$ & 8,000 & 54 & 54 & 53 & 52 \\
\hline & & S22 & 8,000 & 55 & 54 & 53 & 53 \\
\hline \multirow[b]{3}{*}{4} & \multirow{3}{*}{$\begin{array}{c}\text { WV Pav } \\
12.5 \mathrm{~mm} \\
\text { SKID - } \\
8 \% \\
\end{array}$} & $\mathrm{~S} 23$ & 8,000 & 55 & 54 & 53 & 53 \\
\hline & & $\mathrm{S} 25$ & 8,000 & 53 & 53 & 52 & 51 \\
\hline & & $\mathrm{S} 32$ & 8,000 & 53 & 52 & 51 & 51 \\
\hline \multirow[b]{3}{*}{3} & \multirow{3}{*}{$\begin{array}{c}\text { Greer } \\
\mathrm{W} 1 \mathrm{H}- \\
4 \%\end{array}$} & S16 & 16,000 & 45 & 44 & 45 & 44 \\
\hline & & $\mathrm{S} 26$ & 16,000 & 46 & 45 & 45 & 44 \\
\hline & & S27 & 16,000 & 45 & 44 & 43 & 43 \\
\hline \multirow[b]{3}{*}{3} & \multirow{3}{*}{$\begin{array}{c}\text { Greer } \\
\text { W1H - } \\
8 \%\end{array}$} & S29 & 16,000 & 47 & 45 & 45 & 45 \\
\hline & & $\mathrm{S} 30$ & 16,000 & 48 & 46 & 46 & 45 \\
\hline & & S31 & 16,000 & 46 & 45 & 44 & 45 \\
\hline \multirow[b]{3}{*}{4} & \multirow{3}{*}{$\begin{array}{c}\text { WV Pav } \\
12.5 \mathrm{~mm} \\
\text { SKID - } \\
4 \%\end{array}$} & $\mathrm{~S} 20$ & 16,000 & 48 & 48 & 47 & 46 \\
\hline & & S21 & 16,000 & 51 & 50 & 49 & 49 \\
\hline & & S22 & 16,000 & 51 & 49 & 49 & 48 \\
\hline 4 & & S23 & 16,000 & 52 & 51 & 49 & 49 \\
\hline
\end{tabular}




\begin{tabular}{|c|c|c|c|c|c|c|c|}
\hline & WV Pav & S25 & 16,000 & 49 & 48 & 47 & 47 \\
\hline & $\begin{array}{c}\text { SKID - } \\
8 \%\end{array}$ & S32 & 16,000 & 50 & 48 & 47 & 46 \\
\hline \multirow[b]{3}{*}{3} & \multirow{3}{*}{$\begin{array}{c}\text { Greer } \\
\mathrm{W} 1 \mathrm{H}- \\
4 \% \\
\end{array}$} & $\mathrm{~S} 16$ & 32,000 & 42 & 41 & 40 & 39 \\
\hline & & S26 & 32,000 & 41 & 40 & 39 & 38 \\
\hline & & S27 & 32,000 & 41 & 40 & 40 & 39 \\
\hline \multirow[b]{3}{*}{3} & \multirow{3}{*}{$\begin{array}{c}\text { Greer } \\
\text { W1H - } \\
8 \%\end{array}$} & S29 & 32,000 & 43 & 41 & 40 & 40 \\
\hline & & $\mathrm{S} 30$ & 32,000 & 42 & 41 & 40 & 40 \\
\hline & & $\mathrm{S} 31$ & 32,000 & 41 & 39 & 38 & 38 \\
\hline \multirow[b]{3}{*}{4} & \multirow{3}{*}{$\begin{array}{c}\text { WV Pav } \\
12.5 \mathrm{~mm} \\
\text { SKID - } \\
4 \%\end{array}$} & $\mathrm{~S} 20$ & 32,000 & 43 & 41 & 40 & 40 \\
\hline & & S21 & 32,000 & 44 & 43 & 41 & 42 \\
\hline & & $\mathrm{S} 22$ & 32,000 & 43 & 41 & 40 & 40 \\
\hline \multirow[b]{3}{*}{4} & \multirow{3}{*}{$\begin{array}{c}\text { WV Pav } \\
12.5 \mathrm{~mm} \\
\text { SKID - } \\
8 \%\end{array}$} & $\mathrm{~S} 23$ & 32,000 & 45 & 45 & 43 & 42 \\
\hline & & S25 & 32,000 & 44 & 42 & 42 & 41 \\
\hline & & $\mathrm{S} 32$ & 32,000 & 44 & 42 & 42 & 41 \\
\hline \multirow[b]{3}{*}{3} & \multirow{3}{*}{$\begin{array}{c}\text { Greer } \\
\mathrm{W} 1 \mathrm{H}- \\
4 \% \\
\end{array}$} & $\mathrm{~S} 16$ & 48,000 & 40 & 39 & 37 & 37 \\
\hline & & S26 & 48,000 & 39 & 37 & 36 & 35 \\
\hline & & $\mathrm{S} 27$ & 48,000 & 40 & 38 & 37 & 36 \\
\hline \multirow[b]{3}{*}{3} & \multirow{3}{*}{$\begin{array}{c}\text { Greer } \\
\text { W1H - } \\
8 \%\end{array}$} & S29 & 48,000 & 42 & 40 & 39 & 37 \\
\hline & & $\mathrm{S} 30$ & 48,000 & 40 & 38 & 37 & 36 \\
\hline & & $\mathrm{S} 31$ & 48,000 & 40 & 37 & 37 & 36 \\
\hline \multirow[b]{3}{*}{4} & \multirow{3}{*}{$\begin{array}{c}\text { WV Pav } \\
12.5 \mathrm{~mm} \\
\text { SKID - } \\
4 \%\end{array}$} & $\mathrm{~S} 20$ & 48,000 & 42 & 40 & 39 & 39 \\
\hline & & $\mathrm{S} 21$ & 48,000 & 44 & 41 & 40 & 39 \\
\hline & & $\mathrm{S} 22$ & 48,000 & 42 & 40 & 39 & 39 \\
\hline \multirow[b]{3}{*}{4} & \multirow{3}{*}{$\begin{array}{c}\text { WV Pav } \\
12.5 \mathrm{~mm} \\
\text { SKID - } \\
8 \%\end{array}$} & $\mathrm{~S} 23$ & 48,000 & 46 & 44 & 41 & 40 \\
\hline & & S25 & 48,000 & 44 & 42 & 40 & 39 \\
\hline & & $\mathrm{S} 32$ & 48,000 & 43 & 41 & 40 & 39 \\
\hline
\end{tabular}


Table 15: Data for Original and Replicate Statistical Comparison

\begin{tabular}{|c|c|c|c|c|c|}
\hline & & $\begin{array}{c}\text { Original } \\
\text { Sample No. }\end{array}$ & BPNOriginal & $\begin{array}{c}\text { Replicate } \\
\text { Sample No. }\end{array}$ & BPN $N_{\text {Replicate }}$ \\
\hline \multirow{24}{*}{$\begin{array}{l}\text { Sample } \\
\text { Bottoms }\end{array}$} & \multirow{3}{*}{$\begin{array}{c}\text { JFA } \\
12.5 \mathrm{~mm} \mathrm{SR} \\
4 \% \mathrm{VTM}\end{array}$} & 25 & 47.5 & S1 & 38.5 \\
\hline & & 26 & 47.25 & $\mathrm{~S} 2$ & 37.75 \\
\hline & & 27 & 48.75 & S3 & 38.75 \\
\hline & \multirow{3}{*}{$\begin{array}{c}\text { JFA } \\
12.5 \mathrm{~mm} \mathrm{SR} \\
8 \% \mathrm{VTM}\end{array}$} & 28 & 49.75 & S4 & 39.25 \\
\hline & & 29 & 49 & S5 & 39.5 \\
\hline & & 30 & 49.25 & S6 & 39.25 \\
\hline & \multirow{3}{*}{$\begin{array}{c}\text { WVP W1- } \\
\text { RAP 4\% } \\
\text { VTM }\end{array}$} & 31 & 50.75 & S7 & 42.5 \\
\hline & & 32 & 48.75 & S8 & 44.5 \\
\hline & & 33 & 50.5 & S9 & 44 \\
\hline & \multirow{3}{*}{$\begin{array}{c}\text { WVP W1- } \\
\text { RAP 8\% } \\
\text { VTM }\end{array}$} & 34 & 50.75 & $\mathrm{~S} 10$ & 43.75 \\
\hline & & 35 & 50.25 & $\mathrm{~S} 12$ & 43 \\
\hline & & 36 & 48.75 & $\mathrm{~S} 13$ & 43.5 \\
\hline & \multirow{3}{*}{$\begin{array}{c}\text { WVP } \\
12.5 \mathrm{~mm} \mathrm{SR} \\
4 \% \mathrm{VTM}\end{array}$} & 19 & 45.5 & $\mathrm{~S} 20$ & 40 \\
\hline & & 20 & 47.5 & $\mathrm{~S} 21$ & 40 \\
\hline & & 21 & 44.25 & $\mathrm{~S} 22$ & 39.25 \\
\hline & \multirow{3}{*}{$\begin{array}{c}\text { WVP } \\
12.5 \mathrm{~mm} \mathrm{SR} \\
8 \% \mathrm{VTM}\end{array}$} & 22 & 43.75 & $\mathrm{~S} 23$ & 40.75 \\
\hline & & 23 & 43.5 & $\mathrm{~S} 25$ & 38.5 \\
\hline & & 24 & 45.75 & $\mathrm{~S} 32$ & 40.5 \\
\hline & \multirow{3}{*}{$\begin{array}{c}\text { Greer W1H } \\
4 \% \text { VTM }\end{array}$} & 16 & 43 & $\mathrm{~S} 16$ & 39.5 \\
\hline & & 17 & 42.75 & S26 & 39.5 \\
\hline & & 18 & 43 & $\mathrm{~S} 27$ & 39 \\
\hline & \multirow{3}{*}{$\begin{array}{c}\text { Greer W1H } \\
8 \% \text { VTM }\end{array}$} & 13 & 43.75 & $\mathrm{~S} 29$ & 38 \\
\hline & & 14 & 42.5 & $\mathrm{~S} 30$ & 39.25 \\
\hline & & 15 & 43.75 & $\mathrm{~S} 31$ & 39.25 \\
\hline \multirow{12}{*}{$\begin{array}{c}\text { Sample } \\
\text { Tops }\end{array}$} & \multirow{3}{*}{$\begin{array}{c}\text { JFA } \\
12.5 \mathrm{~mm} \mathrm{SR} \\
4 \% \mathrm{VTM}\end{array}$} & 25 & 40.25 & S1 & 41.5 \\
\hline & & 26 & 40 & S2 & 39.75 \\
\hline & & 27 & 41 & S3 & 41.75 \\
\hline & \multirow{3}{*}{$\begin{array}{c}\text { JFA } \\
12.5 \mathrm{~mm} \mathrm{SR} \\
8 \% \text { VTM }\end{array}$} & 28 & 40.5 & S4 & 40.25 \\
\hline & & 29 & 41.75 & S5 & 39 \\
\hline & & 30 & 40.5 & S6 & 41.25 \\
\hline & \multirow{3}{*}{$\begin{array}{c}\text { WVP W1- } \\
\text { RAP 4\% } \\
\text { VTM }\end{array}$} & 31 & 40.5 & S7 & 44.75 \\
\hline & & 32 & 40.75 & S8 & 43.5 \\
\hline & & 33 & 41.5 & S9 & 42.5 \\
\hline & \multirow{3}{*}{$\begin{array}{c}\text { WVP W1- } \\
\text { RAP 8\% } \\
\text { VTM }\end{array}$} & 34 & 41.5 & $\mathrm{~S} 10$ & 43 \\
\hline & & 35 & 41 & $\mathrm{~S} 12$ & 43 \\
\hline & & 36 & 40 & $\mathrm{~S} 13$ & 43.75 \\
\hline
\end{tabular}




\begin{tabular}{|c|c|c|c|c|}
\hline \multirow{3}{*}{$\begin{array}{c}\text { WVP } \\
12.5 \mathrm{~mm} \mathrm{SR} \\
4 \% \mathrm{VTM}\end{array}$} & 19 & 46.25 & S20 & 40 \\
\hline & 20 & 45.75 & $\mathrm{~S} 21$ & 41 \\
\hline & 21 & 47.75 & $\mathrm{~S} 22$ & 40 \\
\hline \multirow{3}{*}{$\begin{array}{c}\text { WVP } \\
12.5 \mathrm{~mm} \mathrm{SR} \\
8 \% \mathrm{VTM}\end{array}$} & 22 & 47.5 & $\mathrm{~S} 23$ & 42.75 \\
\hline & 23 & 46.25 & $\mathrm{~S} 25$ & 41.25 \\
\hline & 24 & 47 & $\mathrm{~S} 32$ & 40.75 \\
\hline \multirow{3}{*}{$\begin{array}{c}\text { Greer W1H } \\
4 \% \text { VTM }\end{array}$} & 16 & 44.5 & S16 & 38.25 \\
\hline & 17 & 43.25 & S26 & 36.75 \\
\hline & 18 & 42.75 & $\mathrm{~S} 27$ & 37.75 \\
\hline \multirow{3}{*}{$\begin{array}{c}\text { Greer W1H } \\
8 \% \text { VTM }\end{array}$} & 13 & 43 & S29 & 39.5 \\
\hline & 14 & 43.5 & $\mathrm{~S} 30$ & 37.75 \\
\hline & 15 & 44.75 & S31 & 37.5 \\
\hline
\end{tabular}

Table 16: Comparison of Average BPN After 48,000 Wheel Passes at 4\% VTM, High Toe

\begin{tabular}{|c|c|c|c|c|}
\hline & \multicolumn{4}{|c|}{ Average BPN } \\
\hline & $\begin{array}{c}\text { Mix 1 } \\
\text { 12.5mm } \\
\text { Skid-RAP }\end{array}$ & $\begin{array}{c}\text { Mix 2 } \\
\text { W1-RAP }\end{array}$ & $\begin{array}{c}\text { Mix 3 } \\
\text { W1H }\end{array}$ & $\begin{array}{c}\text { Mix 4 } \\
\text { 12.5mm } \\
\text { Skid-RAP }\end{array}$ \\
\hline $\begin{array}{c}\text { Original } \\
\text { Experiment }\end{array}$ & 40 & 41 & 44 & 47 \\
\hline $\begin{array}{c}\text { Replicate } \\
\text { Experiment }\end{array}$ & 41 & 44 & 38 & 40 \\
\hline
\end{tabular}

Table 17: Comparison of Average BPN After 48,000 Wheel Passes at 8\% VTM, High Toe

\begin{tabular}{|c|c|c|c|c|}
\hline & \multicolumn{4}{|c|}{ Average BPN } \\
\hline & $\begin{array}{c}\text { Mix 1 } \\
12.5 \mathrm{~mm} \\
\text { Skid-RAP }\end{array}$ & $\begin{array}{c}\text { Mix 2 } \\
\text { W1-RAP }\end{array}$ & $\begin{array}{c}\text { Mix 3 } \\
\text { W1H }\end{array}$ & $\begin{array}{c}\text { Mix 4 } \\
\text { Skid-RAP } \\
\text { Skid-Rm }\end{array}$ \\
\hline $\begin{array}{c}\text { Original } \\
\text { Experiment }\end{array}$ & 41 & 41 & 44 & 47 \\
\hline $\begin{array}{c}\text { Replicate } \\
\text { Experiment }\end{array}$ & 40 & 44 & 38 & 42 \\
\hline
\end{tabular}


Table 18: Comparison of Average BPN After 48,000 Wheel Passes at 4\% VTM, Low Toe

\begin{tabular}{|c|c|c|c|c|}
\hline & \multicolumn{4}{|c|}{ Average BPN } \\
\hline & $\begin{array}{c}\text { Mix 1 } \\
\text { 12.5mm } \\
\text { Skid-RAP }\end{array}$ & $\begin{array}{c}\text { Mix 2 } \\
\text { W1-RAP }\end{array}$ & $\begin{array}{c}\text { Mix 3 } \\
\text { W1H }\end{array}$ & $\begin{array}{c}\text { Mix 4 } \\
\text { Skid-RAP } \\
\text { Skid-RAP }\end{array}$ \\
\hline $\begin{array}{c}\text { Original } \\
\text { Experiment }\end{array}$ & 48 & 50 & 43 & 46 \\
\hline $\begin{array}{c}\text { Replicate } \\
\text { Experiment }\end{array}$ & 38 & 44 & 39 & 40 \\
\hline
\end{tabular}

Table 19: Comparison of Average BPN After 48,000 Wheel Passes at 8\% VTM, Low Toe

\begin{tabular}{|c|c|c|c|c|}
\hline & \multicolumn{4}{|c|}{ Average BPN } \\
\hline & $\begin{array}{c}\text { Mix 1 } \\
\text { 12.5mm } \\
\text { Skid-RAP }\end{array}$ & $\begin{array}{c}\text { Mix 2 } \\
\text { W1-RAP }\end{array}$ & $\begin{array}{c}\text { Mix 3 } \\
\text { W1H }\end{array}$ & $\begin{array}{c}\text { Mix 4 } \\
\text { Skid-RAP }\end{array}$ \\
\hline $\begin{array}{c}\text { Original } \\
\text { Experiment }\end{array}$ & 49 & 50 & 43 & 44 \\
\hline $\begin{array}{c}\text { Replicate } \\
\text { Experiment }\end{array}$ & 39 & 43 & 39 & 40 \\
\hline
\end{tabular}




\section{Appendix C: Skid Resistant Asphalt Experiment Data}

Table 20: BPN data for specimen using High Toe

\begin{tabular}{|c|c|c|c|c|c|c|c|}
\hline Mix No. & Mix Name & $\begin{array}{c}\text { Sample } \\
\text { No. }\end{array}$ & $\begin{array}{l}\text { Wheel } \\
\text { Passes } \\
\end{array}$ & Trial 1 & Trial 2 & Trial 3 & Trial 4 \\
\hline \multirow[b]{3}{*}{1} & \multirow[b]{3}{*}{ Per Design } & 1 & 0 & 77 & 77 & 76 & 76 \\
\hline & & 2 & 0 & 74 & 74 & 74 & 74 \\
\hline & & 3 & 0 & 75 & 74 & 74 & 73 \\
\hline \multirow[b]{3}{*}{2} & \multirow[b]{3}{*}{ Opposite Skid } & 1 & 0 & 81 & 81 & 80 & 80 \\
\hline & & 2 & 0 & 78 & 79 & 77 & 77 \\
\hline & & 3 & 0 & 76 & 77 & 78 & 77 \\
\hline \multirow[b]{3}{*}{3} & \multirow[b]{3}{*}{ No Skid } & 1 & 0 & 74 & 74 & 73 & 74 \\
\hline & & 2 & 0 & 76 & 77 & 76 & 76 \\
\hline & & 3 & 0 & 75 & 75 & 75 & 75 \\
\hline \multirow[b]{3}{*}{4} & \multirow[b]{3}{*}{ All Skid } & 1 & 0 & 79 & 79 & 78 & 77 \\
\hline & & 2 & 0 & 75 & 75 & 76 & 74 \\
\hline & & 3 & 0 & 79 & 78 & 79 & 77 \\
\hline \multirow[b]{3}{*}{1} & \multirow[b]{3}{*}{ Per Design } & 1 & 8,000 & 58 & 56 & 55 & 55 \\
\hline & & 2 & 8,000 & 58 & 56 & 56 & 55 \\
\hline & & 3 & 8,000 & 58 & 56 & 55 & 55 \\
\hline \multirow[b]{3}{*}{2} & \multirow[b]{3}{*}{ Opposite Skid } & 1 & 8,000 & 61 & 59 & 58 & 56 \\
\hline & & 2 & 8,000 & 58 & 56 & 56 & 56 \\
\hline & & 3 & 8,000 & 56 & 56 & 55 & 55 \\
\hline \multirow[b]{3}{*}{3} & \multirow[b]{3}{*}{ No Skid } & 1 & 8,000 & 56 & 55 & 54 & 54 \\
\hline & & 2 & 8,000 & 58 & 57 & 55 & 55 \\
\hline & & 3 & 8,000 & 57 & 57 & 56 & 55 \\
\hline \multirow[b]{3}{*}{4} & \multirow[b]{3}{*}{ All Skid } & 1 & 8,000 & 59 & 58 & 57 & 57 \\
\hline & & 2 & 8,000 & 57 & 55 & 55 & 54 \\
\hline & & 3 & 8,000 & 58 & 56 & 55 & 55 \\
\hline \multirow[b]{3}{*}{1} & \multirow[b]{3}{*}{ Per Design } & 1 & 16,000 & 52 & 50 & 50 & 50 \\
\hline & & 2 & 16,000 & 53 & 52 & 52 & 52 \\
\hline & & 3 & 16,000 & 53 & 51 & 51 & 51 \\
\hline \multirow[b]{3}{*}{2} & \multirow[b]{3}{*}{ Opposite Skid } & 1 & 16,000 & 54 & 52 & 52 & 52 \\
\hline & & 2 & 16,000 & 52 & 51 & 51 & 51 \\
\hline & & 3 & 16,000 & 52 & 51 & 51 & 50 \\
\hline \multirow[b]{3}{*}{3} & \multirow[b]{3}{*}{ No Skid } & 1 & 16,000 & 51 & 51 & 50 & 51 \\
\hline & & 2 & 16,000 & 53 & 51 & 51 & 49 \\
\hline & & 3 & 16,000 & 52 & 50 & 50 & 49 \\
\hline
\end{tabular}




\begin{tabular}{|c|c|c|c|c|c|c|c|}
\hline \multirow[b]{3}{*}{4} & \multirow[b]{3}{*}{ All Skid } & 1 & 16,000 & 52 & 52 & 51 & 50 \\
\hline & & 2 & 16,000 & 52 & 52 & 51 & 50 \\
\hline & & 3 & 16,000 & 52 & 52 & 51 & 51 \\
\hline \multirow[b]{3}{*}{1} & \multirow[b]{3}{*}{ Per Design } & 1 & 32,000 & 51 & 50 & 48 & 47 \\
\hline & & 2 & 32,000 & 52 & 50 & 49 & 49 \\
\hline & & 3 & 32,000 & 50 & 49 & 48 & 47 \\
\hline \multirow[b]{3}{*}{2} & \multirow[b]{3}{*}{ Opposite Skid } & 1 & 32,000 & 51 & 50 & 49 & 49 \\
\hline & & 2 & 32,000 & 51 & 51 & 51 & 49 \\
\hline & & 3 & 32,000 & 51 & 50 & 48 & 47 \\
\hline \multirow[b]{3}{*}{3} & \multirow[b]{3}{*}{ No Skid } & 1 & 32,000 & 50 & 48 & 47 & 46 \\
\hline & & 2 & 32,000 & 51 & 50 & 49 & 48 \\
\hline & & 3 & 32,000 & 50 & 50 & 48 & 47 \\
\hline \multirow[b]{3}{*}{4} & \multirow[b]{3}{*}{ All Skid } & 1 & 32,000 & 51 & 50 & 48 & 48 \\
\hline & & 2 & 32,000 & 51 & 49 & 48 & 47 \\
\hline & & 3 & 32,000 & 51 & 50 & 49 & 49 \\
\hline \multirow[b]{3}{*}{1} & \multirow[b]{3}{*}{ Per Design } & 1 & 48,000 & 46 & 45 & 44 & 43 \\
\hline & & 2 & 48,000 & 48 & 46 & 45 & 44 \\
\hline & & 3 & 48,000 & 48 & 46 & 46 & 44 \\
\hline \multirow[b]{3}{*}{2} & \multirow[b]{3}{*}{ Opposite Skid } & 1 & 48,000 & 48 & 46 & 45 & 44 \\
\hline & & 2 & 48,000 & 48 & 46 & 45 & 44 \\
\hline & & 3 & 48,000 & 48 & 46 & 44 & 43 \\
\hline \multirow[b]{3}{*}{3} & \multirow[b]{3}{*}{ No Skid } & 1 & 48,000 & 46 & 44 & 44 & 42 \\
\hline & & 2 & 48,000 & 47 & 45 & 44 & 43 \\
\hline & & 3 & 48,000 & 46 & 45 & 44 & 43 \\
\hline \multirow[b]{3}{*}{4} & \multirow[b]{3}{*}{ All Skid } & 1 & 48,000 & 47 & 46 & 44 & 43 \\
\hline & & 2 & 48,000 & 47 & 45 & 44 & 43 \\
\hline & & 3 & 48,000 & 48 & 46 & 45 & 44 \\
\hline \multirow[b]{3}{*}{1} & \multirow[b]{3}{*}{ Per Design } & 1 & 80,000 & 46 & 44 & 44 & 43 \\
\hline & & 2 & 80,000 & 47 & 45 & 43 & 42 \\
\hline & & 3 & 80,000 & 45 & 44 & 43 & 42 \\
\hline \multirow[b]{3}{*}{2} & \multirow[b]{3}{*}{ Opposite Skid } & 1 & 80,000 & 47 & 45 & 44 & 42 \\
\hline & & 2 & 80,000 & 45 & 44 & 44 & 42 \\
\hline & & 3 & 80,000 & 46 & 44 & 44 & 41 \\
\hline \multirow[b]{3}{*}{3} & \multirow[b]{3}{*}{ No Skid } & 1 & 80,000 & 44 & 42 & 42 & 40 \\
\hline & & 2 & 80,000 & 45 & 44 & 41 & 41 \\
\hline & & 3 & 80,000 & 46 & 44 & 43 & 42 \\
\hline \multirow[b]{3}{*}{4} & \multirow[b]{3}{*}{ All Skid } & 1 & 80,000 & 46 & 44 & 44 & 42 \\
\hline & & 2 & 80,000 & 45 & 43 & 42 & 41 \\
\hline & & 3 & 80,000 & 46 & 44 & 41 & 42 \\
\hline
\end{tabular}


Table 21: BPN data for specimen using Low Toe

\begin{tabular}{|c|c|c|c|c|c|c|c|}
\hline Mix No. & Mix Name & $\begin{array}{c}\text { Sample } \\
\text { No. }\end{array}$ & $\begin{array}{l}\text { Wheel } \\
\text { Passes }\end{array}$ & Trial 1 & Trial 2 & Trial 3 & Trial 4 \\
\hline \multirow[b]{3}{*}{1} & \multirow[b]{3}{*}{ Per Design } & 1 & 0 & 68 & 67 & 66 & 66 \\
\hline & & 2 & 0 & 71 & 70 & 69 & 69 \\
\hline & & 3 & 0 & 71 & 71 & 71 & 71 \\
\hline \multirow[b]{3}{*}{2} & \multirow[b]{3}{*}{ Opposite Skid } & 1 & 0 & 74 & 73 & 74 & 74 \\
\hline & & 2 & 0 & 72 & 72 & 71 & 71 \\
\hline & & 3 & 0 & 75 & 75 & 74 & 74 \\
\hline \multirow[b]{3}{*}{3} & \multirow[b]{3}{*}{ No Skid } & 1 & 0 & 71 & 70 & 70 & 70 \\
\hline & & 2 & 0 & 70 & 69 & 69 & 69 \\
\hline & & 3 & 0 & 74 & 73 & 72 & 72 \\
\hline \multirow[b]{3}{*}{4} & \multirow[b]{3}{*}{ All Skid } & 1 & 0 & 76 & 74 & 74 & 74 \\
\hline & & 2 & 0 & 74 & 73 & 73 & 72 \\
\hline & & 3 & 0 & 73 & 72 & 74 & 72 \\
\hline \multirow[b]{3}{*}{1} & \multirow[b]{3}{*}{ Per Design } & 1 & 8,000 & 58 & 57 & 57 & 56 \\
\hline & & 2 & 8,000 & 60 & 58 & 57 & 57 \\
\hline & & 3 & 8,000 & 56 & 56 & 56 & 55 \\
\hline \multirow[b]{3}{*}{2} & \multirow[b]{3}{*}{ Opposite Skid } & 1 & 8,000 & 59 & 58 & 56 & 57 \\
\hline & & 2 & 8,000 & 59 & 59 & 57 & 57 \\
\hline & & 3 & 8,000 & 56 & 56 & 56 & 56 \\
\hline \multirow[b]{3}{*}{3} & \multirow[b]{3}{*}{ No Skid } & 1 & 8,000 & 56 & 55 & 55 & 54 \\
\hline & & 2 & 8,000 & 58 & 57 & 57 & 56 \\
\hline & & 3 & 8,000 & 58 & 57 & 56 & 56 \\
\hline \multirow[b]{3}{*}{4} & \multirow[b]{3}{*}{ All Skid } & 1 & 8,000 & 59 & 58 & 57 & 57 \\
\hline & & 2 & 8,000 & 59 & 58 & 57 & 56 \\
\hline & & 3 & 8,000 & 57 & 56 & 55 & 55 \\
\hline \multirow[b]{3}{*}{1} & \multirow[b]{3}{*}{ Per Design } & 1 & 16,000 & 55 & 54 & 53 & 53 \\
\hline & & 2 & 16,000 & 52 & 51 & 51 & 51 \\
\hline & & 3 & 16,000 & 54 & 54 & 54 & 52 \\
\hline \multirow[b]{3}{*}{2} & \multirow[b]{3}{*}{ Opposite Skid } & 1 & 16,000 & 54 & 55 & 54 & 54 \\
\hline & & 2 & 16,000 & 54 & 54 & 54 & 55 \\
\hline & & 3 & 16,000 & 55 & 54 & 53 & 52 \\
\hline \multirow[b]{3}{*}{3} & \multirow[b]{3}{*}{ No Skid } & 1 & 16,000 & 54 & 53 & 52 & 52 \\
\hline & & 2 & 16,000 & 53 & 52 & 51 & 50 \\
\hline & & 3 & 16,000 & 54 & 53 & 52 & 52 \\
\hline \multirow[b]{2}{*}{4} & \multirow[b]{2}{*}{ All Skid } & 1 & 16,000 & 55 & 55 & 54 & 54 \\
\hline & & 2 & 16,000 & 53 & 53 & 53 & 52 \\
\hline
\end{tabular}




\begin{tabular}{|c|c|c|c|c|c|c|c|}
\hline & & 3 & 16,000 & 54 & 54 & 52 & 52 \\
\hline \multirow[b]{3}{*}{1} & \multirow[b]{3}{*}{ Per Design } & 1 & 32,000 & 52 & 51 & 50 & 50 \\
\hline & & 2 & 32,000 & 54 & 52 & 51 & 50 \\
\hline & & 3 & 32,000 & 53 & 52 & 51 & 50 \\
\hline \multirow[b]{3}{*}{2} & \multirow[b]{3}{*}{ Opposite Skid } & 1 & 32,000 & 53 & 52 & 50 & 50 \\
\hline & & 2 & 32,000 & 53 & 51 & 50 & 50 \\
\hline & & 3 & 32,000 & 52 & 51 & 50 & 49 \\
\hline \multirow[b]{3}{*}{3} & \multirow[b]{3}{*}{ No Skid } & 1 & 32,000 & 48 & 46 & 47 & 46 \\
\hline & & 2 & 32,000 & 51 & 50 & 49 & 49 \\
\hline & & 3 & 32,000 & 52 & 49 & 49 & 48 \\
\hline \multirow[b]{3}{*}{4} & \multirow[b]{3}{*}{ All Skid } & 1 & 32,000 & 53 & 50 & 50 & 49 \\
\hline & & 2 & 32,000 & 52 & 50 & 50 & 49 \\
\hline & & 3 & 32,000 & 52 & 51 & 50 & 49 \\
\hline \multirow[b]{3}{*}{1} & \multirow[b]{3}{*}{ Per Design } & 1 & 48,000 & 46 & 45 & 44 & 44 \\
\hline & & 2 & 48,000 & 46 & 44 & 43 & 42 \\
\hline & & 3 & 48,000 & 48 & 46 & 45 & 44 \\
\hline \multirow[b]{3}{*}{2} & \multirow[b]{3}{*}{ Opposite Skid } & 1 & 48,000 & 47 & 46 & 45 & 44 \\
\hline & & 2 & 48,000 & 46 & 45 & 44 & 43 \\
\hline & & 3 & 48,000 & 47 & 45 & 44 & 43 \\
\hline \multirow[b]{3}{*}{3} & \multirow[b]{3}{*}{ No Skid } & 1 & 48,000 & 45 & 43 & 42 & 41 \\
\hline & & 2 & 48,000 & 45 & 44 & 44 & 43 \\
\hline & & 3 & 48,000 & 47 & 45 & 44 & 43 \\
\hline \multirow[b]{3}{*}{4} & \multirow[b]{3}{*}{ All Skid } & 1 & 48,000 & 48 & 47 & 44 & 44 \\
\hline & & 2 & 48,000 & 45 & 45 & 43 & 41 \\
\hline & & 3 & 48,000 & 46 & 44 & 44 & 42 \\
\hline \multirow[b]{3}{*}{1} & \multirow[b]{3}{*}{ Per Design } & 1 & 80,000 & 45 & 45 & 44 & 43 \\
\hline & & 2 & 80,000 & 45 & 44 & 43 & 41 \\
\hline & & 3 & 80,000 & 47 & 45 & 45 & 44 \\
\hline \multirow[b]{3}{*}{2} & \multirow[b]{3}{*}{ Opposite Skid } & 1 & 80,000 & 49 & 46 & 45 & 44 \\
\hline & & 2 & 80,000 & 46 & 46 & 45 & 43 \\
\hline & & 3 & 80,000 & 46 & 44 & 43 & 42 \\
\hline \multirow[b]{3}{*}{3} & \multirow[b]{3}{*}{ No Skid } & 1 & 80,000 & 45 & 43 & 41 & 41 \\
\hline & & 2 & 80,000 & 46 & 45 & 44 & 43 \\
\hline & & 3 & 80,000 & 44 & 43 & 43 & 42 \\
\hline \multirow[b]{3}{*}{4} & \multirow[b]{3}{*}{ All Skid } & 1 & 80,000 & 48 & 45 & 44 & 43 \\
\hline & & 2 & 80,000 & 45 & 43 & 41 & 41 \\
\hline & & 3 & 80,000 & 46 & 45 & 43 & 42 \\
\hline
\end{tabular}


Table 22: Average BPN Numbers for $9.5 \mathrm{~mm}$ SKID Study at 7\% VTM with High Toe

\begin{tabular}{|c|c|c|c|c|}
\hline \multicolumn{5}{|c|}{ Average BPN } \\
\hline Wheel Passes & $\mathbf{0 \%}$ & $\mathbf{4 0 \%}$ & $\mathbf{5 9 \%}$ & $\mathbf{9 9 \%}$ \\
\hline 0 & 75.0 & 74.8 & 78.4 & 77.2 \\
\hline 8000 & 55.8 & 56.1 & 56.8 & 56.3 \\
\hline 16000 & 50.7 & 54.4 & 54.6 & 51.3 \\
\hline 32000 & 48.7 & 49.2 & 49.8 & 49.3 \\
\hline 48000 & 44.4 & 45.4 & 45.6 & 45.2 \\
\hline 80000 & 42.8 & 44.0 & 44.0 & 43.3 \\
\hline
\end{tabular}

Table 23: Average BPN Numbers for $9.5 \mathrm{~mm}$ SKID Study at 7\% VTM with Low Toe

\begin{tabular}{|c|c|c|c|c|}
\hline \multicolumn{5}{|c|}{ Average BPN } \\
\hline Wheel Passes & $\mathbf{0 \%}$ & $\mathbf{4 0 \%}$ & $\mathbf{5 9 \%}$ & $\mathbf{9 9 \%}$ \\
\hline 0 & 70.8 & 69.2 & 73.3 & 73.4 \\
\hline 8000 & 56.3 & 56.9 & 57.2 & 57.0 \\
\hline 16000 & 52.3 & 52.8 & 54.0 & 53.4 \\
\hline 32000 & 48.7 & 51.3 & 50.9 & 50.4 \\
\hline 48000 & 43.8 & 44.8 & 44.9 & 44.4 \\
\hline 80000 & 43.3 & 44.3 & 44.9 & 43.8 \\
\hline
\end{tabular}

Table 24: Skid Aggregate Content vs Average BPN

\begin{tabular}{|c|c|c|c|}
\hline Mixture & $\begin{array}{c}\text { Skid Aggregate, } \\
\text { \% }\end{array}$ & $\begin{array}{c}\text { High Toe } \\
\text { Average BPN }\end{array}$ & $\begin{array}{c}\text { Low Toe } \\
\text { Average BPN }\end{array}$ \\
\hline All Skid & 99 & 43.3 & 43.8 \\
\hline Opposite Skid & 59 & 44.0 & 44.9 \\
\hline Per Design & 40 & 44.0 & 44.3 \\
\hline No Skid & 0 & 42.8 & 43.3 \\
\hline
\end{tabular}




\section{Appendix D: Insoluble Residue Data}

\section{Asphalt Burn-off}

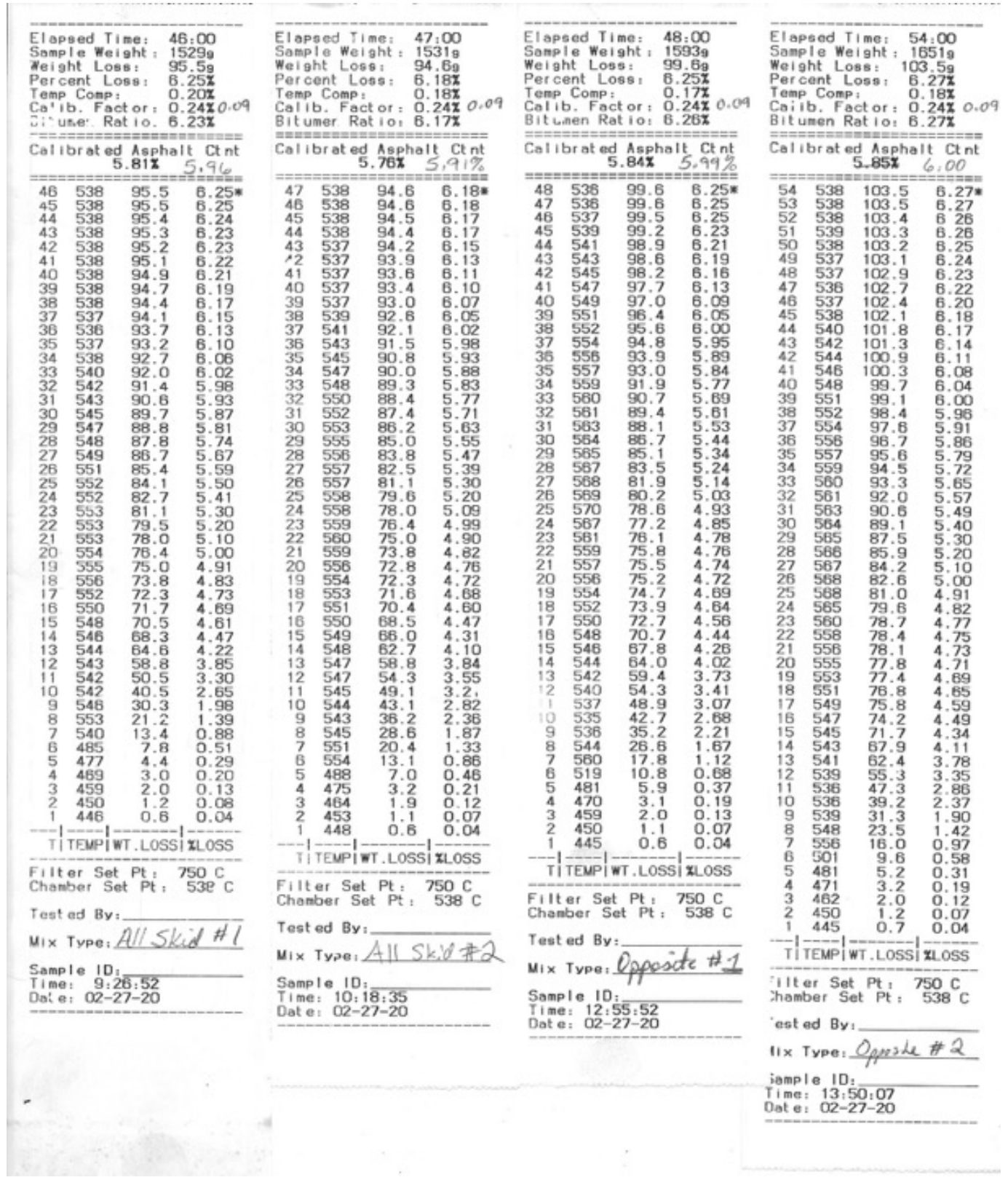

Figure 27: Binder Burn-off Tickets for All Skid and Opposite Skid 


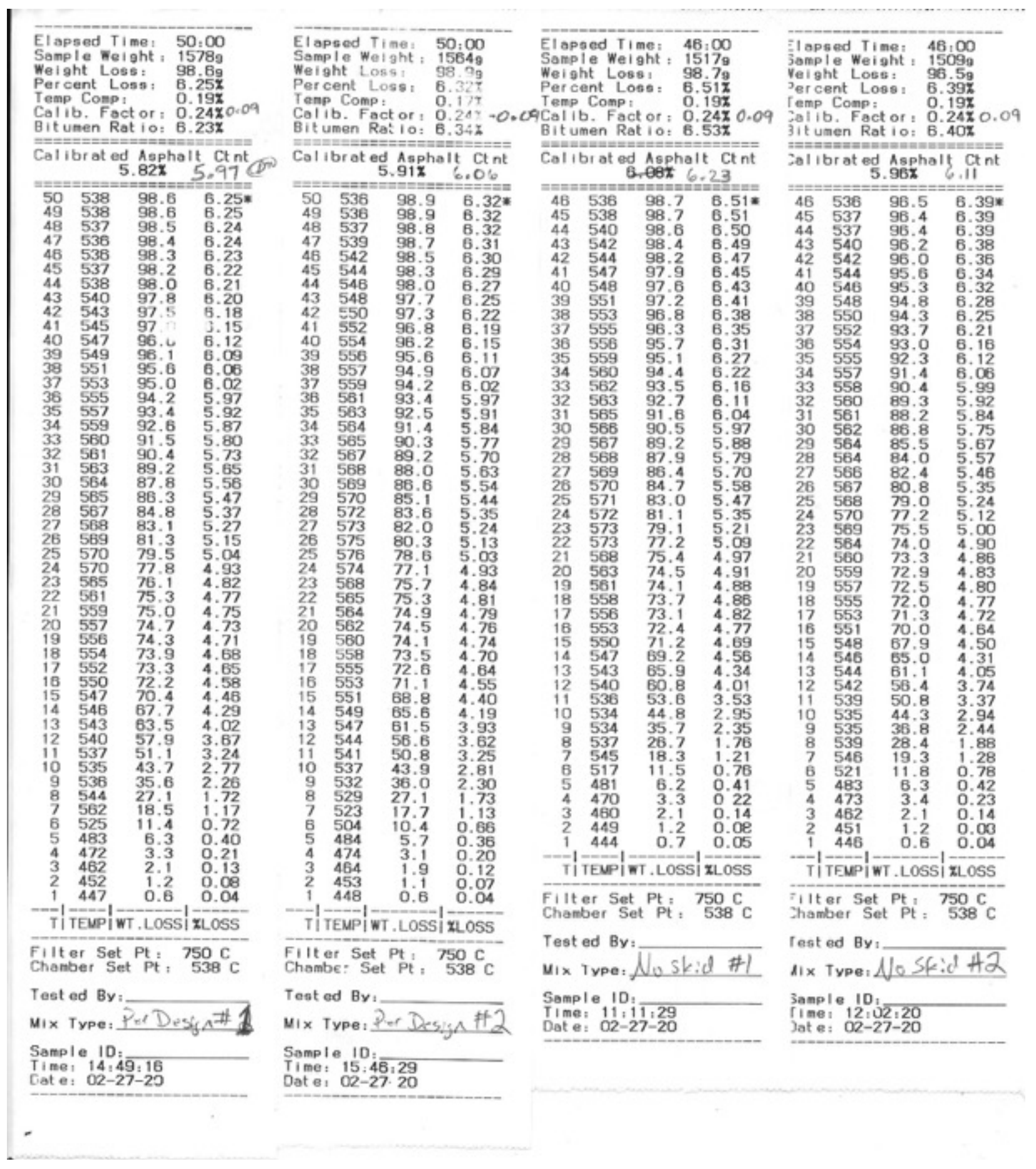

Figure 28: Binder burn-off tickets for Per Design and No Skid 


Asphalt Content By Ignition Method (AASHTO T308, Test Method A) And
Mechanical Analysis Of Extracted Aggregate - AASHTO T30

\begin{tabular}{|c|c|c|c|c|}
\hline \multicolumn{3}{|c|}{ Minus $75 \mu \mathrm{m}$ Material } & \multicolumn{2}{|c|}{ Washed Grading } \\
\hline \multirow{3}{*}{$(\mathrm{L})$} & \multirow{2}{*}{$\begin{array}{l}\text { Weight In Pan After Gradation } \\
\text { Loss On Wash ( Q ) } \\
\text { Total - } 200(75 \mu \mathrm{m}) \text { Material }(\mathrm{L}+\mathrm{Q})\end{array}$} & 10.2 & \multirow{3}{*}{$\begin{array}{l}\text { (N) Weight Before Wash } \\
\text { (O) Weight After Wash } \\
\text { (Q) Loss (N - O) }\end{array}$} & 1436.2 \\
\hline & & $\frac{85.6}{0.8}$ & & $\frac{1350.6}{856}$ \\
\hline & Total Aggregate in Sample For Grad & $\frac{95.8}{\text { ulations: }}$ & & $\frac{85.6}{1436.2}$ \\
\hline
\end{tabular}

\begin{tabular}{|c|c|c|c|c|c|}
\hline \multicolumn{6}{|c|}{ Gradation Analysis } \\
\hline $\begin{array}{l}\text { Sieve } \\
\text { Size }\end{array}$ & $\begin{array}{l}\text { Weight } \\
\text { Retained }\end{array}$ & $\begin{array}{l}\text { Percent } \\
\text { Retained }\end{array}$ & $\begin{array}{l}\text { Percent } \\
\text { Passing }\end{array}$ & $\begin{array}{c}\text { Reported } \\
\text { Percent Passing }\end{array}$ & $\begin{array}{l}\text { Tolerance } \\
\text { Limits }\end{array}$ \\
\hline \multicolumn{6}{|l|}{2 in $(50 \mathrm{~mm})$} \\
\hline \multicolumn{6}{|l|}{$11 / 2 \mathrm{in}(37.5 \mathrm{~mm})$} \\
\hline 1 in $(25 \mathrm{~mm})$ & & 0.0 & 99.97 & 100 & \\
\hline $3 / 4$ in $(19 \mathrm{~mm})$ & & 0.0 & 99.97 & 100 & \\
\hline $1 / 2 \mathrm{in}(12.5 \mathrm{~mm})$ & & 0.0 & 99.97 & 100 & 100 \\
\hline $3 / 8$ in $(9.5 \mathrm{~mm})$ & 8.7 & 0.6 & 99.37 & 99 & $90-100$ \\
\hline No. $4(4.75 \mathrm{~mm})$ & 397.0 & 27.6 & 71.77 & 72 & 90 Max \\
\hline No. 8 (2.36 mm) & 384.2 & 26.8 & 44.97 & 45 & $39-51$ \\
\hline No. $16(1.18 \mu \mathrm{m})$ & 236.8 & 16.5 & 28.47 & 28 & \\
\hline No. $30(600 \mu \mathrm{m})$ & 150.9 & 10.5 & 17.97 & 18 & \\
\hline No. $50(300 \mu \mathrm{m})$ & 88.8 & 6.2 & 11.77 & 12 & \\
\hline No. $200(75 \mu \mathrm{m})$ & 73.6 & 5.1 & 6.67 & 6.7 & $2.0-10.0$ \\
\hline$-200(75 \mu \mathrm{m})(\mathrm{M})$ & 95.8 & 6.67 & & & \\
\hline Total Wt. (W) & 1435.8 & & & & \\
\hline
\end{tabular}

\begin{tabular}{|c|c|c|}
\hline $0.2 \%$ Check: & W - Q & $100(\mathrm{O}-\mathrm{X}) / \mathrm{O}$ \\
\cline { 2 - 3 }$=$ Total Weight $(\mathrm{X})$ & 1350.2 & 0.03 \\
\hline
\end{tabular}

Attach all asphalt content oven printouts to this report.
The Summation Of The Retained Weights Of All Of The Sieves Plus The Pan Weight Must Check The Dry Weight After Wash $(\mathrm{O})$ Within $0.2 \%$ Of The Total Weight $(X)$.

Figure 29: Gradation of Aggregates from binder burn-off for All Skid Sample \#1 


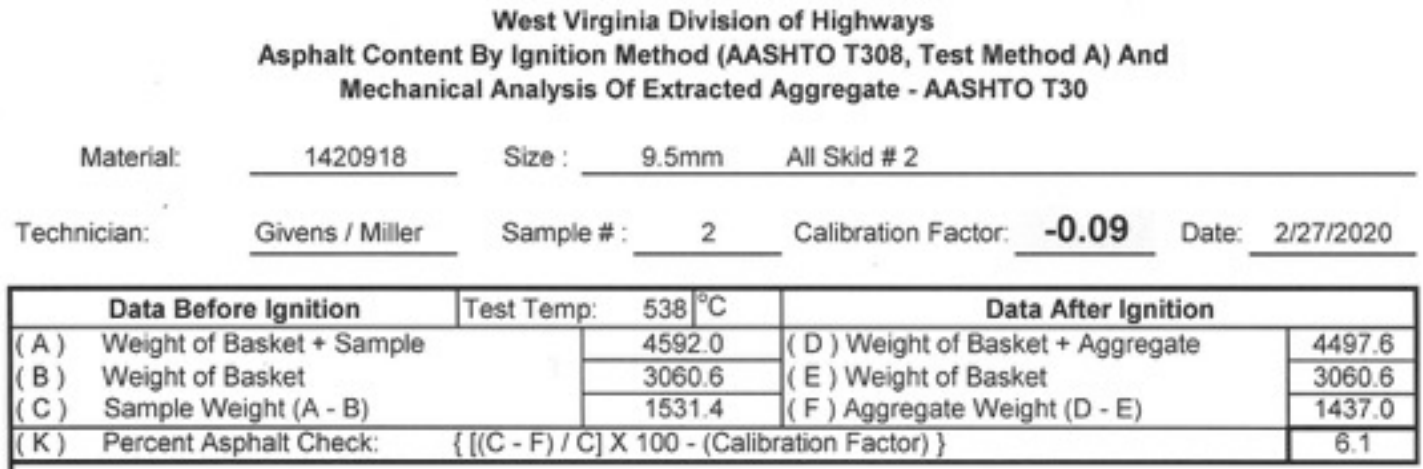

\begin{tabular}{|c|c|c|c|c|}
\hline \multicolumn{3}{|c|}{ Minus $75 \mu \mathrm{m}$ Material } & \multicolumn{2}{|c|}{ Washed Grading } \\
\hline \multirow{3}{*}{$\begin{array}{l}\text { (L) } \\
\text { (M) }\end{array}$} & \multirow{3}{*}{$\begin{array}{l}\text { Weight In Pan After Gradation } \\
\text { Loss On Wash ( Q ) } \\
\text { Total - } 200(75 \mu \mathrm{m}) \text { Material }(\mathrm{L}+\mathrm{Q})\end{array}$} & 7.8 & \multirow{3}{*}{$\begin{array}{l}\text { (N) Weight Before Wash } \\
\text { (O) Weight After Wash } \\
\text { (Q) Loss (N-O) }\end{array}$} & 1437.0 \\
\hline & & 85.1 & & $\frac{1351.9}{85.1}$ \\
\hline & & 92.9 & & $\frac{85.1}{14370}$ \\
\hline
\end{tabular}

\begin{tabular}{|c|c|c|c|c|c|}
\hline \multicolumn{6}{|c|}{ Gradation Analysis } \\
\hline $\begin{array}{l}\text { Sieve } \\
\text { Size }\end{array}$ & $\begin{array}{c}\text { Weight } \\
\text { Retained }\end{array}$ & $\begin{array}{l}\text { Percent } \\
\text { Retained }\end{array}$ & $\begin{array}{l}\text { Percent } \\
\text { Passing }\end{array}$ & $\begin{array}{c}\text { Reported } \\
\text { Percent Passing }\end{array}$ & $\begin{array}{c}\text { Tolerance } \\
\text { Limits }\end{array}$ \\
\hline \multicolumn{6}{|l|}{2 in $(50 \mathrm{~mm})$} \\
\hline \multicolumn{6}{|l|}{$11 / 2$ in $(37.5 \mathrm{~mm})$} \\
\hline $1 \mathrm{in}(25 \mathrm{~mm})$ & & 0.0 & 99.86 & 100 & \\
\hline $3 / 4$ in $(19 \mathrm{~mm})$ & & 0.0 & 99.86 & 100 & \\
\hline $1 / 2$ in $(12.5 \mathrm{~mm})$ & & 0.0 & 99.86 & 100 & 100 \\
\hline $3 / 8$ in $(9.5 \mathrm{~mm})$ & 22.0 & 1.5 & 98.36 & 98 & $90-100$ \\
\hline No. $4(4.75 \mathrm{~mm})$ & 406.8 & 28.3 & 70.06 & 70 & 90 Max \\
\hline No. $8(2.36 \mathrm{~mm})$ & 374.3 & 26.0 & 44.06 & 44 & $39-51$ \\
\hline №. $16(1.18 \mu \mathrm{m})$ & 231.9 & 16.1 & 27.96 & 28 & \\
\hline No. $30(600 \mu \mathrm{m})$ & 148.3 & 10.3 & 17.66 & 18 & \\
\hline No. $50(300 \mu \mathrm{m})$ & 87.9 & 6.1 & 11.56 & 12 & \\
\hline No. $200(75 \mu \mathrm{m})$ & 72.8 & 5.1 & 6.46 & 6.5 & $2.0=10.0$ \\
\hline$-200(75 \mu \mathrm{m})(\mathrm{M})$ & 92.9 & 6.46 & & & \\
\hline Total Wt. (W) & 1436.9 & & & & \\
\hline
\end{tabular}

\begin{tabular}{|c|c|c|}
\hline $0.2 \%$ Check: & W - Q & $100(0-X) / O$ \\
\cline { 2 - 3 }$=$ Total Weight $(X)$ & $\underline{1351.8}$ & $\underline{0.01} \%$ \\
\hline
\end{tabular}

Attach all asphalt content oven printouts to this report.

The Summation Of The Retained Weights Of All Of The Sieves Plus The Pan Weight Must Check The Dry Weight After Wash $(\mathrm{O})$ Within $0.2 \%$ Of The Total Weight $(X)$.

Figure 30: Gradation of Aggregates from binder burn-off for All Skid Sample \#2 


\begin{tabular}{|c|c|c|c|c|c|c|c|c|}
\hline & & $\begin{array}{r}\text { Asphalt Conte } \\
\text { Mechan }\end{array}$ & $\begin{array}{l}\text { West Virgi } \\
\text { te Bynition I } \\
\text { cal Analysis O }\end{array}$ & $\begin{array}{l}\text { ia Divis } \\
\text { lethod }(f \\
\text { Extract }\end{array}$ & $\begin{array}{l}\text { of Highways } \\
\text { SHTO T308, Test Me } \\
\text { Aggregate - AASHT }\end{array}$ & $\begin{array}{l}\operatorname{hod} \mathrm{A}) \mathrm{Ar} \\
\mathrm{T} 30\end{array}$ & & \\
\hline & Material: & 1420918 & Size & $9.5 \mathrm{~mm}$ & Opposite Skid \# 1 & & & \\
\hline Tech & nician: & Givens / Miller & Sample \# & 5 & Calibration Factor: & -0.09 & Date: & $2 / 27 / 2020$ \\
\hline & Data B & Ignition & Test Temp: & $538{ }^{\circ} \mathrm{C}$ & & a After Ig & tion & \\
\hline$(\mathrm{A})$ & Weight & lasket + Sample & & 4651.8 & (D) Weight of Bas & et + Aggre & & 4553.8 \\
\hline (B) & Weight & lasket & & 3058.4 & ( E ) Weight of Bas! & & & 3058.4 \\
\hline (C) & Sample & ight $(A-B)$ & & 1593.4 & (F) Aggregate We & $h t(D-E)$ & & 1495.4 \\
\hline$(\mathrm{K})$ & Percent & phalt Check: & {$[(\mathrm{C}-\mathrm{F}) / \mathrm{C}] \mathrm{X}$} & $100-(\mathrm{C}$ & ration Factor) \} & & & $\overline{6.1}$ \\
\hline
\end{tabular}

\begin{tabular}{|c|c|c|c|c|}
\hline \multicolumn{3}{|c|}{ Minus $75 \mu \mathrm{m}$ Material } & \multicolumn{2}{|c|}{ Washed Grading } \\
\hline \multirow{3}{*}{$\begin{array}{l}(\mathrm{L}) \\
(\mathrm{M})\end{array}$} & \multirow{3}{*}{$\begin{array}{l}\text { Weight In Pan After Gradation } \\
\text { Loss On Wash }(Q) \\
\text { Total - } 200(75 \mu \mathrm{m}) \text { Material }(\mathrm{L}+\mathrm{Q})\end{array}$} & 7.4 & \multirow{3}{*}{$\begin{array}{l}\text { (N) Weight Before Wash } \\
\text { (O) Weight After Wash } \\
\text { (Q) Loss (N - O) }\end{array}$} & 1495.4 \\
\hline & & 87,7 & & 1407.7 \\
\hline & & 95.1 & & 87.7 \\
\hline (S) & Total Aggregate in Sample For Grad & Ulations. & (Line (F) Above) & 1495.4 \\
\hline
\end{tabular}

\begin{tabular}{|c|c|c|c|c|c|}
\hline \multicolumn{6}{|c|}{ Gradation Analysis } \\
\hline $\begin{array}{l}\text { Sieve } \\
\text { Size }\end{array}$ & $\begin{array}{c}\text { Weight } \\
\text { Retained }\end{array}$ & $\begin{array}{l}\text { Percent } \\
\text { Retained }\end{array}$ & $\begin{array}{l}\text { Percent } \\
\text { Passing }\end{array}$ & $\begin{array}{c}\text { Reported } \\
\text { Percent Passing }\end{array}$ & $\begin{array}{l}\text { Tolerance } \\
\text { Limits }\end{array}$ \\
\hline \multicolumn{6}{|l|}{2 in $(50 \mathrm{~mm})$} \\
\hline \multicolumn{6}{|l|}{$11 / 2$ in $(37.5 \mathrm{~mm})$} \\
\hline 1 in $(25 \mathrm{~mm})$ & & 0.0 & 99.95 & 100 & \\
\hline $3 / 4$ in $(19 \mathrm{~mm})$ & & 0.0 & 99.95 & 100 & \\
\hline $1 / 2$ in $(12.5 \mathrm{~mm})$ & & 0.0 & 99.95 & 100 & 100 \\
\hline $3 / 8$ in $(9.5 \mathrm{~mm})$ & 13.6 & 0.9 & 99.05 & 99 & $90=100$ \\
\hline NNo. $4(4.75 \mathrm{~mm})$ & 441.8 & 29.5 & 69.55 & 70 & $90 \operatorname{Max}$ \\
\hline NNo. $8(2.36 \mathrm{~mm})$ & 368.6 & 24.6 & 44.95 & 45 & $39-51$ \\
\hline No. $16(1.18 \mu \mathrm{m})$ & 255.2 & 17.1 & 27.85 & 28 & \\
\hline No. $30(600 \mu \mathrm{m})$ & 155.1 & 10.4 & 17.45 & 17 & \\
\hline No. $50(300 \mu m)$ & 88.8 & 5.9 & 11.55 & 12 & \\
\hline №. $200(75 \mu \mathrm{m})$ & 77.2 & 5.2 & 6.35 & 6.4 & $2.0-10.0$ \\
\hline$-200(75 \mu \mathrm{m})(\mathrm{M})$ & 95.1 & 6.35 & & & \\
\hline Total Wt. (W) & 1495.4 & & & & \\
\hline
\end{tabular}

\begin{tabular}{|c|c|c|}
\hline \multirow{2}{*}{$\begin{aligned} & 0.2 \% \text { Check: } \\
= & \text { Total Weight }(X)\end{aligned}$} & $\mathrm{W}-\mathrm{Q}$ & $100(0-X) / 0$ \\
\hline & 1407.7 & $\%$ \\
\hline
\end{tabular}

Aftach all asphait content oven printouts to this report.
The Summation Of The Retained Weights Of All Of The Sieves Plus The Pan Weight Must Check The Dry Weight After Wash $(O)$ Within $0.2 \%$ Of The Total Weight $(X)$.

Figure 31: Gradation of Aggregates from binder burn-off for Opposite Skid Sample \#1 
West Virginia Division of Highways Asphalt Content By Ignition Method (AASHTO T308, Test Method A) And Mechanical Analysis Of Extracted Aggregate - AASHTO T30

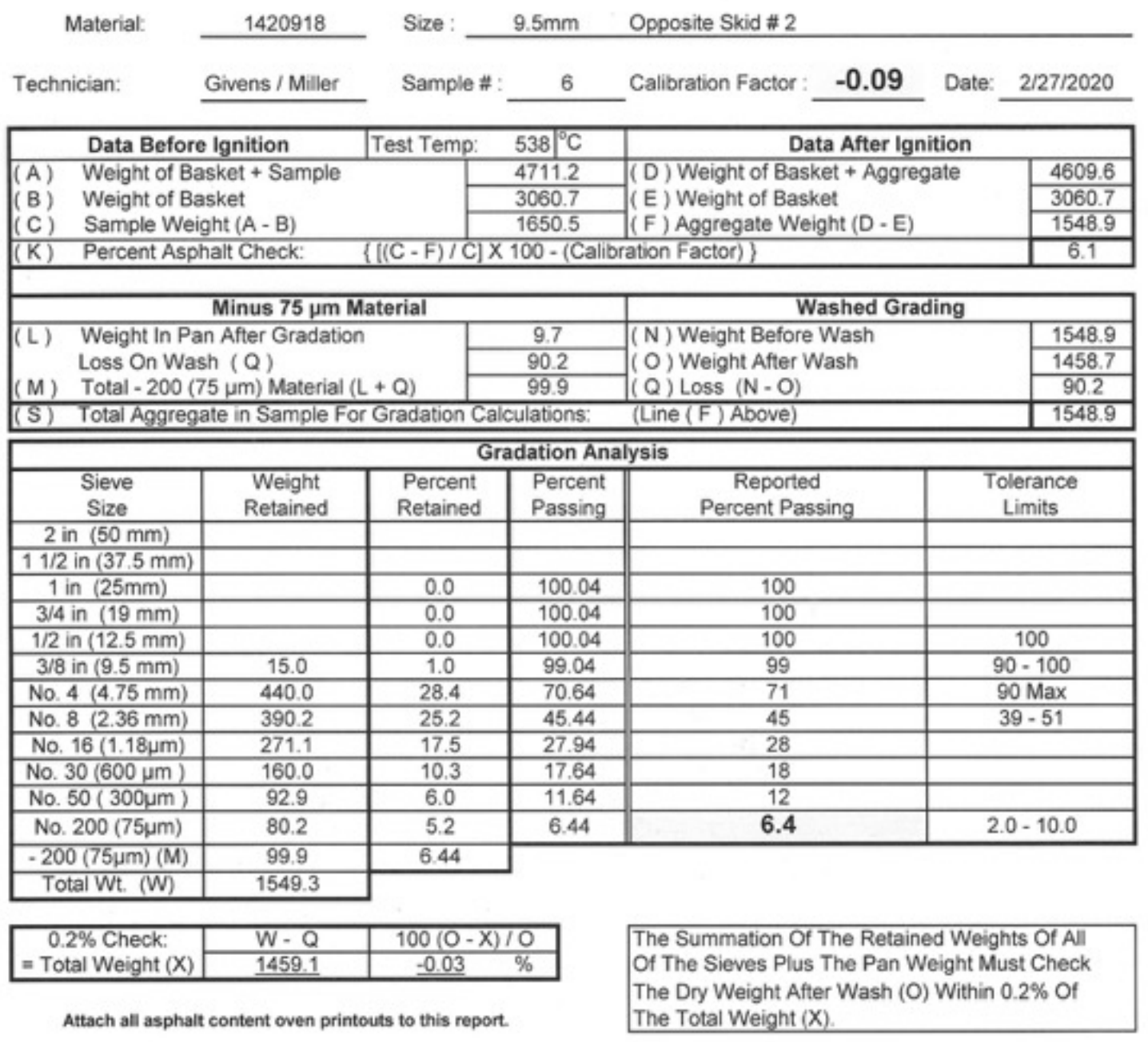

Figure 32: Gradation of Aggregates from binder burn-off for Opposite Skid Sample \#2 
West Virginia Division of Highways

Asphalt Content By Ignition Method (AASHTO T308, Test Method A) And

Mechanical Analysis Of Extracted Aggregate - AASHTO T30

\begin{tabular}{|c|c|c|c|c|c|c|c|c|}
\hline \multirow{2}{*}{\multicolumn{2}{|c|}{$\begin{array}{l}\text { Material: } \\
\text { Technician: }\end{array}$}} & 1420918 & \multirow{2}{*}{$\begin{array}{l}\text { Size : } \\
\text { Sample \# }\end{array}$} & $9.5 \mathrm{~mm}$ & \multicolumn{4}{|l|}{ Per Design \# 1} \\
\hline & & Givens / Miller & & 7 & Calibration Factor: & -0.09 & Date: & $2 / 27 / 2020$ \\
\hline \multicolumn{3}{|c|}{ Data Before Ignition } & Test Temp: & \begin{tabular}{l|l|l}
538 & ${ }^{\circ} \mathrm{C}$ \\
\end{tabular} & \multicolumn{4}{|c|}{ Data After Ignition } \\
\hline \multirow{3}{*}{$\begin{array}{l}(\mathrm{A}) \\
(\mathrm{B}) \\
(\mathrm{C}) \\
\end{array}$} & \multirow{3}{*}{\multicolumn{2}{|c|}{$\begin{array}{l}\text { Weight of Basket + Sample } \\
\text { Weight of Basket } \\
\text { Sample Weight (A - B) }\end{array}$}} & & 4636.3 & \multirow{3}{*}{\multicolumn{3}{|c|}{$\begin{array}{l}\text { (D) Weight of Basket + Aggregate } \\
\text { (E) Weight of Basket } \\
\text { (F) Aggregate Weight (D - E) }\end{array}$}} & 4540.3 \\
\hline & & & & 3058.4 & & & & 3058.4 \\
\hline & & & & 1577.9 & & & & 1481.9 \\
\hline$(\mathrm{K})$ & \multicolumn{2}{|c|}{ Percent Asphalt Check: } & $\{[(\mathrm{C}-\mathrm{F}) / \mathrm{C}]\rangle$ & $100-(\mathrm{Cz}$ & ration Factor) \} & & & 6.0 \\
\hline
\end{tabular}

\begin{tabular}{|c|c|c|c|c|}
\hline \multicolumn{3}{|c|}{ Minus $75 \mu \mathrm{m}$ Material } & \multicolumn{2}{|c|}{ Washed Grading } \\
\hline \multirow{3}{*}{$(\mathrm{L})$} & \multirow{3}{*}{$\begin{array}{l}\text { Weight In Pan After Gradation } \\
\text { Loss On Wash }(\mathrm{Q}) \\
\text { Total - } 200(75 \mu \mathrm{m}) \text { Material }(\mathrm{L}+\mathrm{Q})\end{array}$} & 5.0 & \multirow{3}{*}{$\begin{array}{l}\text { (N) Weight Before Wash } \\
\text { (O) Weight After Wash } \\
\text { (Q) Loss (N-O) }\end{array}$} & 1481.9 \\
\hline & & 89.1 & & 1392.8 \\
\hline & & 94.1 & & 89.1 \\
\hline (S) & Total Aggregate in Sample For Grad & Ilations: & (Line ( $F$ ) Above) & 1481.9 \\
\hline
\end{tabular}

\begin{tabular}{|c|c|c|c|c|c|}
\hline \multicolumn{6}{|c|}{ Gradation Analysis } \\
\hline $\begin{array}{c}\text { Sieve } \\
\text { Size }\end{array}$ & $\begin{array}{c}\text { Weight } \\
\text { Retained }\end{array}$ & $\begin{array}{l}\text { Percent } \\
\text { Retained }\end{array}$ & $\begin{array}{l}\text { Percent } \\
\text { Passing }\end{array}$ & $\begin{array}{c}\text { Reported } \\
\text { Percent Passing }\end{array}$ & $\begin{array}{l}\text { Tolerance } \\
\text { Limits }\end{array}$ \\
\hline \multicolumn{6}{|l|}{2 in $(50 \mathrm{~mm})$} \\
\hline \multicolumn{6}{|l|}{$11 / 2$ in $(37.5 \mathrm{~mm})$} \\
\hline 1 in $(25 \mathrm{~mm})$ & & 0.0 & 99.94 & 100 & \\
\hline $3 / 4$ in $(19 \mathrm{~mm})$ & & 0.0 & 99.94 & 100 & \\
\hline $1 / 2$ in $(12.5 \mathrm{~mm})$ & & 0.0 & 99.94 & 100 & 100 \\
\hline $3 / 8 \mathrm{in}(9.5 \mathrm{~mm})$ & 21.2 & 1.4 & 98.54 & 99 & $90-100$ \\
\hline No. $4(4.75 \mathrm{~mm})$ & 418.5 & 28.2 & 70.34 & 70 & $90 \operatorname{Max}$ \\
\hline No. $8(2.36 \mathrm{~mm})$ & 377.6 & 25.5 & 44.84 & 45 & $39-51$ \\
\hline No. $16(1.18 \mu m)$ & 252.7 & 17.1 & 27.74 & 28 & \\
\hline No. $30(600 \mu \mathrm{m})$ & 150.5 & 10.2 & 17.54 & 18 & \\
\hline No. $50(300 \mu m)$ & 92.6 & 6.2 & 11.34 & 11 & \\
\hline No. $200(75 \mu \mathrm{m})$ & 74.5 & 5.0 & 6.34 & 6.3 & $2.0=10.0$ \\
\hline$-200(75 \mu \mathrm{m})(\mathrm{M})$ & 94.1 & 6.34 & & & \\
\hline Total Wt. (W) & 1481.7 & & & & \\
\hline
\end{tabular}

\begin{tabular}{|c|c|c|}
\hline $0.2 \%$ Check: & W- Q & $100(0-X) / 0$ \\
\cline { 2 - 3 }$=$ Total Weight $(\mathrm{X})$ & 1392.6 & $\underline{0.01} \%$ \\
\hline
\end{tabular}

Attach all asphalt content oven printouts to this report.
The Summation Of The Retained Weights Of All Of The Sieves Plus The Pan Weight Must Check The Dry Weight After Wash (O) Within $0.2 \%$ Of The Total Weight $(\mathbf{X})$.

Figure 33: Gradation of Aggregates from binder burn-off for Per Design Sample \#1 


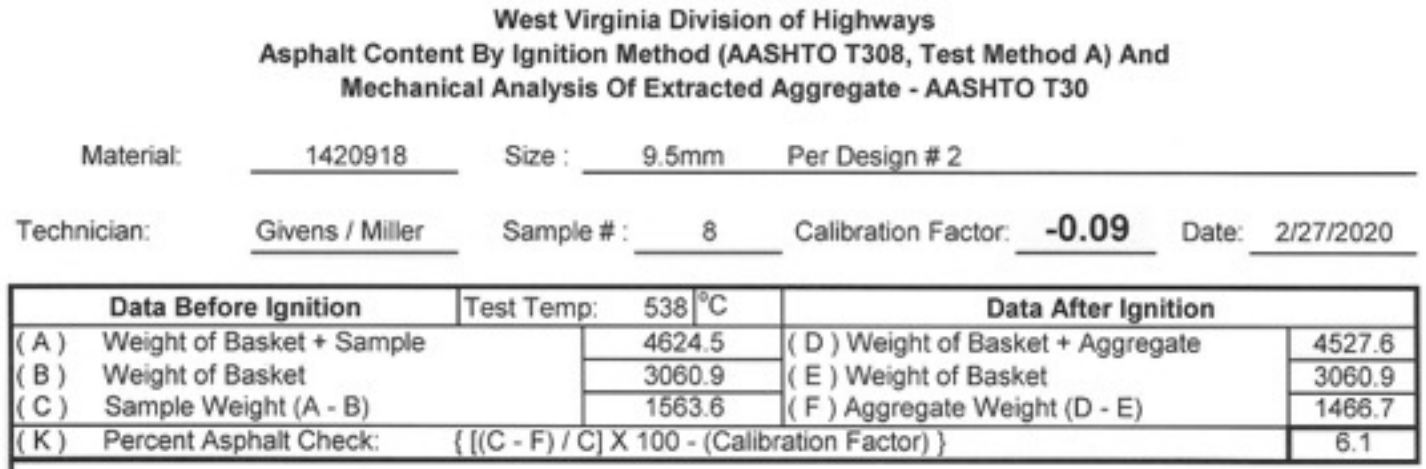

\begin{tabular}{|c|c|c|c|c|}
\hline \multicolumn{3}{|c|}{ Minus $75 \mu \mathrm{m}$ Material } & \multicolumn{2}{|c|}{ Washed Grading } \\
\hline \multirow{2}{*}{$\begin{array}{l}(\mathrm{L}) \\
(\mathrm{M})\end{array}$} & \multirow{2}{*}{$\begin{array}{l}\text { Weight In Pan After Gradation } \\
\text { Loss On Wash }(Q) \\
\text { Total - } 200(75 \mu \mathrm{m}) \text { Material }(\mathrm{L}+\mathrm{Q})\end{array}$} & 4.4 & \multirow{3}{*}{$\begin{array}{l}\text { (N) Weight Before Wash } \\
\text { (O) Weight After Wash } \\
\text { (Q) Loss (N - O) }\end{array}$} & 1466.7 \\
\hline & & $\begin{array}{l}88.3 \\
927\end{array}$ & & $\begin{array}{c}1378.4 \\
88.3\end{array}$ \\
\hline (S) & Total Aggregate in Sample For Grad & $\frac{92.1}{\text { Calculations: }}$ & & $\frac{88.3}{1466.7}$ \\
\hline
\end{tabular}

\begin{tabular}{|c|c|c|c|c|c|}
\hline \multicolumn{6}{|c|}{ Gradation Analysis } \\
\hline $\begin{array}{l}\text { Sieve } \\
\text { Size }\end{array}$ & $\begin{array}{l}\text { Weight } \\
\text { Retained }\end{array}$ & $\begin{array}{l}\text { Percent } \\
\text { Retained }\end{array}$ & $\begin{array}{l}\text { Percent } \\
\text { Passing }\end{array}$ & $\begin{array}{c}\text { Reported } \\
\text { Percent Passing }\end{array}$ & $\begin{array}{l}\text { Tolerance } \\
\text { Limits }\end{array}$ \\
\hline \multicolumn{6}{|l|}{2 in $(50 \mathrm{~mm})$} \\
\hline \multicolumn{6}{|l|}{$11 / 2$ in $(37.5 \mathrm{~mm})$} \\
\hline 1 in $(25 \mathrm{~mm})$ & & 0.0 & 100.02 & 100 & \\
\hline $3 / 4$ in $(19 \mathrm{~mm})$ & & 0.0 & 100.02 & 100 & \\
\hline $1 / 2$ in $(12.5 \mathrm{~mm})$ & & 0.0 & 100.02 & 100 & 100 \\
\hline $3 / 8$ in $(9.5 \mathrm{~mm})$ & 14.7 & 1.0 & 99.02 & 99 & $90-100$ \\
\hline No. $4(4.75 \mathrm{~mm})$ & 425.5 & 29.0 & 70.02 & 70 & 90 Max \\
\hline No. $8(2.36 \mathrm{~mm})$ & 366.7 & 25.0 & 45.02 & 45 & $39-51$ \\
\hline No. $16(1.18 \mu \mathrm{m})$ & 248.7 & 17.0 & 28.02 & 28 & \\
\hline No. $30(600 \mu \mathrm{m})$ & 152.9 & 10.4 & 17.62 & 18 & \\
\hline No. $50(300 \mu \mathrm{m})$ & 92.4 & 6.3 & 11.32 & 11 & \\
\hline No. $200(75 \mu \mathrm{m})$ & 73.5 & 5.0 & 6.32 & 6.3 & $2.0-10.0$ \\
\hline$-200(75 \mu m)(M)$ & 92.7 & 6.32 & & & \\
\hline Total Wt. (W) & 1467.1 & & & & \\
\hline
\end{tabular}

\begin{tabular}{|c|c|c|}
\hline $0.2 \%$ Check: & W - Q & $100(\mathrm{O}-\mathrm{X}) / \mathrm{O}$ \\
\cline { 2 - 3 }$=$ Total Weight $(\mathrm{X})$ & 1378.8 & $-0.03 \%$ \\
\hline
\end{tabular}

Attach all asphalt content oven printouts to this report.
The Summation Of The Retained Weights Of All Of The Sieves Plus The Pan Weight Must Check The Dry Weight After Wash $(\mathrm{O})$ Within $0.2 \%$ Of The Total Weight $(X)$.

Figure 34: Gradation of Aggregates from binder burn-off for Per Design Sample \#2 


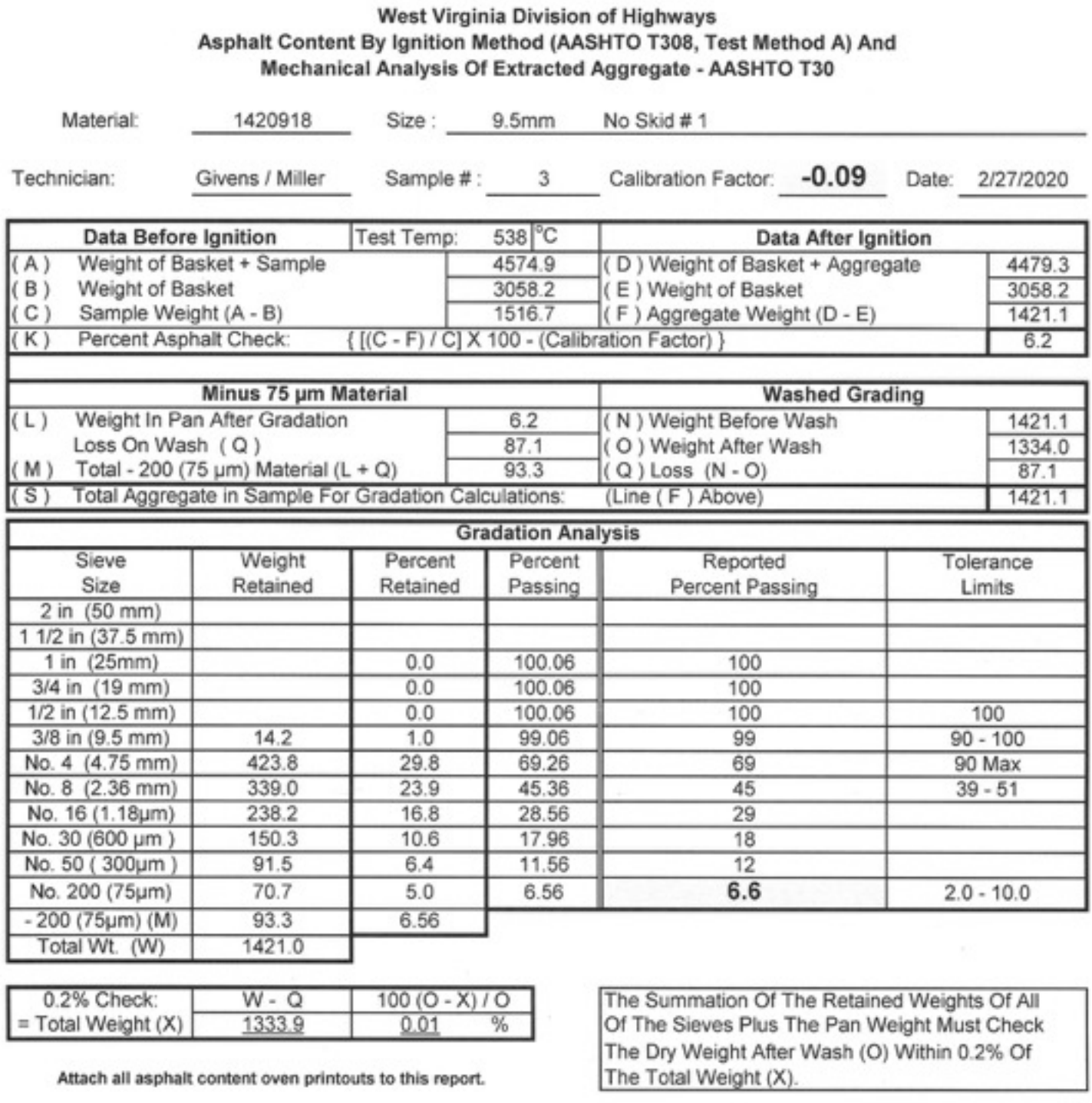

Figure 35: Gradation of Aggregates from binder burn-off for No Skid Sample \#1 


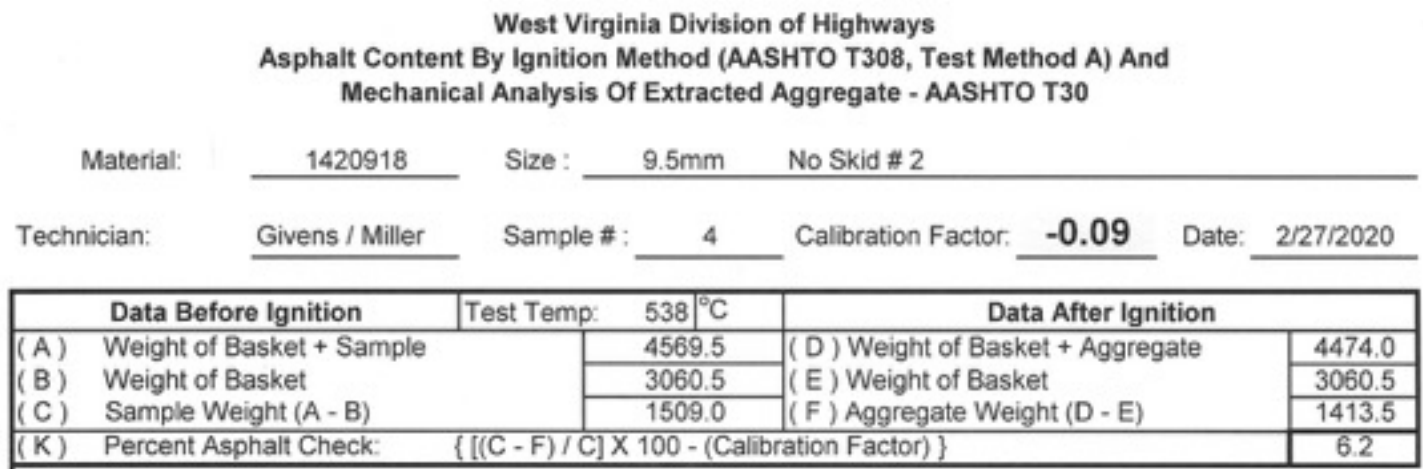

\begin{tabular}{|c|c|c|c|c|}
\hline \multicolumn{3}{|c|}{ Minus $75 \mu \mathrm{m}$ Material } & \multicolumn{2}{|c|}{ Washed Grading } \\
\hline \multirow{3}{*}{$\begin{array}{l}(\mathrm{L}) \\
(\mathrm{M}) \\
\end{array}$} & \multirow{3}{*}{$\begin{array}{l}\text { Weight In Pan After Gradation } \\
\text { Loss On Wash ( Q ) } \\
\text { Total - } 200(75 \mu \mathrm{m}) \text { Material }(L+Q)\end{array}$} & 6.1 & \multirow{3}{*}{$\begin{array}{l}\text { (N) Weight Before Wash } \\
\text { (O) Weight After Wash } \\
\text { (Q) Loss (N-O) }\end{array}$} & 1413.5 \\
\hline & & 85.6 & & 1327.9 \\
\hline & & 91.7 & & 85.6 \\
\hline (S) & Total Aggregate in Sample For Grad: & Calculations: & (Line (F) Above) & 1413.5 \\
\hline
\end{tabular}

\begin{tabular}{|c|c|c|c|c|c|}
\hline \multicolumn{6}{|c|}{ Gradation Analysis } \\
\hline $\begin{array}{l}\text { Sieve } \\
\text { Size }\end{array}$ & $\begin{array}{c}\text { Weight } \\
\text { Retained }\end{array}$ & $\begin{array}{l}\text { Percent } \\
\text { Retained }\end{array}$ & $\begin{array}{l}\text { Percent } \\
\text { Passing }\end{array}$ & $\begin{array}{c}\text { Reported } \\
\text { Percent Passing }\end{array}$ & $\begin{array}{l}\text { Tolerance } \\
\text { Limits }\end{array}$ \\
\hline \multicolumn{6}{|l|}{2 in $(50 \mathrm{~mm})$} \\
\hline \multicolumn{6}{|l|}{$11 / 2$ in $(37.5 \mathrm{~mm})$} \\
\hline $1 \mathrm{in}(25 \mathrm{~mm})$ & & 0.0 & 99.98 & 100 & \\
\hline $3 / 4$ in $(19 \mathrm{~mm})$ & & 0.0 & 99.98 & 100 & \\
\hline $1 / 2 \mathrm{in}(12.5 \mathrm{~mm})$ & & 0.0 & 99.98 & 100 & 100 \\
\hline $3 / 8$ in $(9.5 \mathrm{~mm})$ & 19.8 & 1.4 & 98.58 & 99 & $90-100$ \\
\hline No. $4(4.75 \mathrm{~mm})$ & 414.5 & 29.3 & 69.28 & 69 & 90 Max \\
\hline No. $8(2.36 \mathrm{~mm})$ & 342.4 & 24.2 & 45.08 & 45 & $39-51$ \\
\hline №. $16(1.18 \mu \mathrm{m})$ & 239.5 & 16.9 & 28.18 & 28 & \\
\hline No. $30(600 \mu \mathrm{m})$ & 146.3 & 10.4 & 17.78 & .18 & \\
\hline NNo. $50(300 \mu m)$ & 90.2 & 6.4 & 11.38 & 11 & \\
\hline No. 200 (75um) & 69.1 & 4.9 & 6.48 & 6.5 & $2.0=10.0$ \\
\hline$-200(75 \mu \mathrm{m})(\mathrm{M})$ & 91.7 & 6.48 & & & \\
\hline Total Wt. (W) & 1413.5 & & & & \\
\hline
\end{tabular}

\begin{tabular}{|c|c|c|}
\hline $0.2 \%$ Check: & W - Q & $100(\mathrm{O}-\mathrm{X}) / \mathrm{O}$ \\
\cline { 2 - 3 }$=$ Total Weight $(\mathrm{X})$ & $\underline{1327.9}$ & $\underline{0} \%$ \\
\hline
\end{tabular}

Attach all asphalt content oven printouts to this report.
The Summation Of The Retained Weights Of All Of The Sieves Plus The Pan Weight Must Check The Dry Weight After Wash (O) Within $0.2 \%$ Of The Total Weight $(X)$

Figure 36: Gradation of Aggregates from binder burn-off for No Skid Sample \#2 


\section{Insoluble Residue per WVDOH Method}

Table 25: IR Data for WVDOH Method All Skid Sample \#1

\begin{tabular}{|l|c|c|c|c|c|c|}
\hline Sampled: & & & Weight & \multicolumn{2}{|c|}{ Non-Quartz } & Quartz \\
\cline { 4 - 6 } Test Run: & & Size Mesh & $\mathrm{g}$ & Vol \% & $\mathrm{g}$ & $\mathrm{g}$ \\
\hline Source: & & +30 & 0.9 & $100 \%$ & 0.90 & 0.00 \\
\hline Location: & & +50 & 0.9 & $98 \%$ & 0.88 & 0.02 \\
\hline Sample Type: & & +100 & 2.7 & $30 \%$ & 0.81 & 1.89 \\
\hline Sample Wt., g: & 203.3 & +200 & 24.2 & $3 \%$ & 0.73 & 23.47 \\
\hline $\begin{array}{l}\text { Insoluble Residue Wt., } \\
\text { g: }\end{array}$ & 32.3 & -200 & 3.5 & N/A & +200 Qtz.,g: & 25.39 \\
\hline Sieving Loss/Gain, \%: & 0.3 & Total: & 32.2 & & $+\mathbf{2 0 0}$ Qtz.,\%: & 12 \\
\hline
\end{tabular}

Table 26: IR Data for WVDOH Method All Skid Sample \#2

\begin{tabular}{|l|c|c|c|c|c|c|}
\hline Sampled: & & & Weight & \multicolumn{2}{|c|}{ Non-Quartz } & Quartz \\
\cline { 4 - 6 } Test Run: & & Size Mesh & $\mathrm{g}$ & Vol \% & $\mathrm{g}$ & $\mathrm{g}$ \\
\hline Source: & & +30 & 0.9 & $99 \%$ & 0.89 & 0.01 \\
\hline Location: & & +50 & 1.1 & $99 \%$ & 1.09 & 0.01 \\
\hline Sample Type: & & +100 & 1.9 & $30 \%$ & 0.57 & 1.33 \\
\hline Sample Wt., g: & 202.1 & +200 & 24.7 & $5 \%$ & 1.24 & 23.47 \\
\hline $\begin{array}{l}\text { Insoluble Residue Wt., } \\
\text { g: }\end{array}$ & 33.1 & -200 & 4.2 & N/A & +200 Qtz.,g: & 24.82 \\
\hline Sieving Loss/Gain, \%: & 0.9 & Total: & 32.8 & & $+\mathbf{2 0 0}$ Qtz.,\%: & 12 \\
\hline
\end{tabular}

Table 27: IR Data for WVDOH Method Opposite Skid Sample \#1

\begin{tabular}{|l|c|c|c|c|c|c|}
\hline Sampled: & & \multirow{2}{*}{ Size Mesh } & Weight & \multicolumn{2}{|c|}{ Non-Quartz } & Quartz \\
\cline { 4 - 6 } & & $\mathrm{g}$ & Vol \% & $\mathrm{g}$ & $\mathrm{g}$ \\
\hline Test Run: & & +30 & 1.2 & $100 \%$ & 1.19 & 0.01 \\
\hline Source: & & +50 & 2.8 & $99 \%$ & 2.77 & 0.03 \\
\hline Location: & & +100 & 4.6 & $85 \%$ & 3.91 & 0.69 \\
\hline Sample Type: & 208.1 & +200 & 14 & $55 \%$ & 7.70 & 6.30 \\
\hline Sample Wt., g: & & & & & & \\
\hline $\begin{array}{l}\text { Insoluble Residue Wt., } \\
\text { g: }\end{array}$ & 37 & -200 & 14.2 & N/A & +200 Qtz.,g: & 7.02 \\
\hline Sieving Loss/Gain, \%: & 0.5 & Total: & 36.8 & & $\mathbf{+ 2 0 0}$ Qtz., \%: & 3 \\
\hline
\end{tabular}


Table 28: IR Data for WVDOH Method Opposite Skid Sample \#2

\begin{tabular}{|l|c|c|c|c|c|c|}
\hline \multirow{2}{*}{ Sampled: } & & \multirow{2}{*}{ Size Mesh } & Weight & \multicolumn{2}{|c|}{ Non-Quartz } & Quartz \\
\cline { 4 - 7 } & & $\mathrm{g}$ & Vol \% & $\mathrm{g}$ & $\mathrm{g}$ \\
\hline Test Run: & & +30 & 3.3 & $100 \%$ & 3.28 & 0.02 \\
\hline Source: & & +50 & 4.3 & $93 \%$ & 4.00 & 0.30 \\
\hline Location: & & +100 & 3.6 & $80 \%$ & 2.88 & 0.72 \\
\hline Sample Type: & 206.5 & +200 & 11.4 & $50 \%$ & 5.70 & 5.70 \\
\hline Sample Wt., g: & 36.1 & -200 & 13.3 & N/A & +200 Qtz.,g: & 6.74 \\
\hline $\begin{array}{l}\text { Insoluble Residue Wt., } \\
\text { g: }\end{array}$ & 0.6 & Total: & 35.9 & & $+\mathbf{2 0 0}$ Qtz.,\%: & 3 \\
\hline Sieving Loss/Gain, \%: & & & & & \\
\hline
\end{tabular}

Table 29: IR Data for WVDOH Method Per Design Sample \#1

\begin{tabular}{|c|c|c|c|c|c|c|}
\hline Sampled: & & \multirow[b]{2}{*}{ Size Mesh } & Weight & \multicolumn{2}{|c|}{ Non-Quartz } & Quartz \\
\hline Test Run: & & & $\mathrm{g}$ & Vol \% & $\mathrm{g}$ & $\mathrm{g}$ \\
\hline Source: & & +30 & 0.8 & $100 \%$ & 0.80 & 0.00 \\
\hline Location: & & +50 & 1.1 & $100 \%$ & 1.09 & 0.01 \\
\hline Sample Type: & & +100 & 2.1 & $15 \%$ & 0.32 & 1.79 \\
\hline Sample Wt., g: & 204.9 & +200 & 21.6 & $3 \%$ & 0.65 & 20.95 \\
\hline $\begin{array}{l}\text { Insoluble Residue Wt., } \\
\text { g: }\end{array}$ & 30.9 & -200 & 5.2 & N/A & +200 Qtz.,g: & 22.75 \\
\hline Sieving Loss/Gain, \%: & 0.3 & Total: & 30.8 & & +200 Qtz.,\%: & 11 \\
\hline
\end{tabular}

Table 30: IR Data for WVDOH Method Per Design Sample \#2

\begin{tabular}{|l|c|c|c|c|c|c|}
\hline Sampled: & & \multirow{2}{*}{ Size Mesh } & Weight & \multicolumn{2}{|c|}{ Non-Quartz } & Quartz \\
\cline { 5 - 7 } Test Run: & & g & Vol \% & $\mathrm{g}$ & $\mathrm{g}$ \\
\hline Source: & & +30 & 1 & $100 \%$ & 1.00 & 0.01 \\
\hline Location: & & +50 & 1.3 & $99 \%$ & 1.29 & 0.01 \\
\hline Sample Type: & & +100 & 2.2 & $20 \%$ & 0.44 & 1.76 \\
\hline Sample Wt., g: & 206.6 & +200 & 22 & $2 \%$ & 0.44 & 21.56 \\
\hline $\begin{array}{l}\text { Insoluble Residue Wt., } \\
\text { g: }\end{array}$ & 32.2 & -200 & 5.3 & N/A & +200 Qtz.,g: & 23.34 \\
\hline Sieving Loss/Gain, \%: & 1.2 & Total: & 31.8 & & $+\mathbf{2 0 0}$ Qtz.,\%: & 11 \\
\hline
\end{tabular}


Table 31: IR Data for WVDOH Method No Skid Sample \#1

\begin{tabular}{|l|c|c|c|c|c|c|}
\hline \multirow{2}{*}{ Sampled: } & & \multirow{2}{*}{ Size Mesh } & Weight & \multicolumn{2}{|c|}{ Non-Quartz } & Quartz \\
\cline { 4 - 7 } & & $\mathrm{g}$ & Vol \% & $\mathrm{g}$ & $\mathrm{g}$ \\
\hline Test Run: & & +30 & 2.3 & $100 \%$ & 2.29 & 0.01 \\
\hline Source: & & +50 & 3.6 & $100 \%$ & 3.58 & 0.02 \\
\hline Location: & & +100 & 4.6 & $95 \%$ & 4.37 & 0.23 \\
\hline Sample Type: & 205.1 & +200 & 10.3 & $75 \%$ & 7.73 & 2.58 \\
\hline Sample Wt., g: & & & & & & \\
\hline $\begin{array}{l}\text { Insoluble Residue Wt., } \\
\text { g: }\end{array}$ & 36 & -200 & 15 & N/A & +200 Qtz.,g: & 2.83 \\
\hline Sieving Loss/Gain, \%: & 0.6 & Total: & 35.8 & & $+\mathbf{2 0 0}$ Qtz.,\%: & 1 \\
\hline
\end{tabular}

Table 32: IR Data for WVDOH Method No Skid Sample \#2

\begin{tabular}{|l|r|c|c|c|c|c|}
\hline Sampled: & & & Weight & \multicolumn{2}{|c|}{ Non-Quartz } & Quartz \\
\cline { 5 - 7 } & & Size Mesh & $\mathrm{g}$ & Vol \% & $\mathrm{g}$ & $\mathrm{g}$ \\
\hline Sest Run: & & +30 & 1.8 & $100 \%$ & 1.79 & 0.01 \\
\hline Lource: & & +50 & 3.1 & $99 \%$ & 3.07 & 0.03 \\
\hline Samplion: Type: & & +100 & 4.4 & $93 \%$ & 4.09 & 0.31 \\
\hline Sample Wt., g: & 207.8 & +200 & 11.2 & $80 \%$ & 8.96 & 2.24 \\
\hline $\begin{array}{l}\text { Insoluble Residue Wt., } \\
\text { g: }\end{array}$ & 36.2 & -200 & 15.4 & N/A & +200 Qtz.,g: & 2.59 \\
\hline Sieving Loss/Gain, \%: & 0.8 & Total: & 35.9 & & $\mathbf{+ 2 0 0}$ Qtz.,\%: & 1 \\
\hline
\end{tabular}




\section{Insoluble Residue per Material Passing WVDOH Method}

Table 33: IR Data for Material Passing WVDOH Method All Skid Sample \#1

\begin{tabular}{|l|c|c|c|c|c|c|}
\hline Sampled: & & \multirow{2}{*}{} & Weight & \multicolumn{2}{|c|}{ Non-Quartz } & Quartz \\
\cline { 1 - 4 } \cline { 5 - 7 } Test Run: & & Size Mesh & $\mathrm{g}$ & Vol \% & $\mathrm{g}$ & $\mathrm{g}$ \\
\hline Source: & & +30 & - & - & - & - \\
\hline Location: & & +50 & 0.9 & $75 \%$ & 0.68 & 0.23 \\
\hline Sample Type: & & +100 & 4.8 & $7 \%$ & 0.34 & 4.46 \\
\hline Sample Wt., g: & 204.7 & +200 & 43.7 & $2 \%$ & 0.87 & 42.83 \\
\hline $\begin{array}{l}\text { Insoluble Residue Wt., } \\
\text { g: }\end{array}$ & 51 & -200 & 1.7 & N/A & +200 Qtz.,g: & 47.52 \\
\hline Sieving Loss/Gain, \%: & -0.2 & Total: & 51.1 & & $+\mathbf{2 0 0}$ Qtz.,\%: & 23 \\
\hline
\end{tabular}

Table 34: IR Data for Material Passing WVDOH Method All Skid Sample \#2

\begin{tabular}{|l|r|c|c|c|c|c|}
\hline Sampled: & & \multirow{2}{*}{} & Weight & \multicolumn{2}{|c|}{ Non-Quartz } & Quartz \\
\cline { 1 - 4 } \cline { 5 - 7 } Test Run: & & Size Mesh & $\mathrm{g}$ & Vol \% & $\mathrm{g}$ & $\mathrm{g}$ \\
\hline Source: & & +30 & - & - & - & - \\
\hline Location: & & +50 & 0.8 & $80 \%$ & 0.64 & 0.16 \\
\hline Sample Type: & & +100 & 5.1 & $7 \%$ & 0.36 & 4.74 \\
\hline Sample Wt., g: & 210.6 & +200 & 47.7 & $1 \%$ & 0.48 & 47.22 \\
\hline $\begin{array}{l}\text { Insoluble Residue Wt., } \\
\text { g: }\end{array}$ & 55.9 & -200 & 2.2 & N/A & +200 Qtz.,g: & 52.13 \\
\hline Sieving Loss/Gain, \%: & 0.2 & Total: & 55.8 & & $+\mathbf{2 0 0}$ Qtz.,\%: & 25 \\
\hline
\end{tabular}

Table 35: IR Data for Material Passing WVDOH Method Opposite Skid Sample \#1

\begin{tabular}{|l|c|c|c|c|c|c|}
\hline Sampled: & & & Weight & \multicolumn{2}{|c|}{ Non-Quartz } & Quartz \\
\cline { 1 - 4 } \cline { 5 - 7 } Test Run: & & Size Mesh & $\mathrm{g}$ & Vol \% & $\mathrm{g}$ & $\mathrm{g}$ \\
\hline Source: & & +30 & - & - & - & - \\
\hline Location: & & +50 & 2.2 & $98 \%$ & 2.16 & 0.04 \\
\hline Sample Type: & & +100 & 4.7 & $50 \%$ & 2.35 & 2.35 \\
\hline Sample Wt., g: & 207.1 & +200 & 19.4 & $15 \%$ & 2.91 & 16.49 \\
\hline $\begin{array}{l}\text { Insoluble Residue Wt., } \\
\text { g: }\end{array}$ & 36.2 & -200 & 9.8 & N/A & +200 Qtz.,g: & 18.88 \\
\hline Sieving Loss/Gain, \%: & 0.3 & Total: & 36.1 & & $+\mathbf{2 0 0}$ Qtz.,\%: & 9 \\
\hline
\end{tabular}


Table 36: IR Data for Material Passing WVDOH Method Opposite Skid Sample \#2

\begin{tabular}{|l|r|c|c|c|c|c|}
\hline Sampled: & & & Weight & \multicolumn{2}{|c|}{ Non-Quartz } & Quartz \\
\cline { 1 - 4 } \cline { 5 - 7 } Test Run: & & Size Mesh & $\mathrm{g}$ & Vol \% & $\mathrm{g}$ & $\mathrm{g}$ \\
\hline Source: & & +30 & - & - & - & - \\
\hline Location: & & +50 & 1.1 & $97 \%$ & 1.07 & 0.03 \\
\hline Sample Type: & & +100 & 4.5 & $50 \%$ & 2.25 & 2.25 \\
\hline Sample Wt., g: & 206.2 & +200 & 21.1 & $20 \%$ & 4.22 & 16.88 \\
\hline $\begin{array}{l}\text { Insoluble Residue Wt., } \\
\text { g: }\end{array}$ & 38.9 & -200 & 12 & N/A & +200 Qtz.,g: & 19.16 \\
\hline Sieving Loss/Gain, \%: & 0.5 & Total: & 38.7 & & $+\mathbf{2 0 0}$ Qtz.,\%: & 9 \\
\hline
\end{tabular}

Table 37: IR Data for Material Passing WVDOH Method Per Design Sample \#1

\begin{tabular}{|l|c|c|c|c|c|c|}
\hline Sampled: & & \multirow{2}{*}{ Size Mesh } & Weight & \multicolumn{2}{|c|}{ Non-Quartz } & Quartz \\
\cline { 1 - 4 } \cline { 5 - 7 } Test Run: & & $\mathrm{g}$ & Vol \% & $\mathrm{g}$ & $\mathrm{g}$ \\
\hline Source: & & +30 & - & - & - & - \\
\hline Location: & & +50 & 0.8 & $93 \%$ & 0.74 & 0.06 \\
\hline Sample Type: & & +100 & 5.1 & $7 \%$ & 0.36 & 4.74 \\
\hline Sample Wt., g: & 208.5 & +200 & 40.3 & $1 \%$ & 0.40 & 39.90 \\
\hline $\begin{array}{l}\text { Insoluble Residue Wt., } \\
\text { g: }\end{array}$ & 48.4 & -200 & 2.3 & N/A & +200 Qtz.,g: & 44.70 \\
\hline Sieving Loss/Gain, \%: & -0.2 & Total: & 48.5 & & $\mathbf{+ 2 0 0}$ Qtz.,\%: & 21 \\
\hline
\end{tabular}

Table 38: IR Data for Material Passing WVDOH Method Per Design Sample \#2

\begin{tabular}{|l|c|c|c|c|c|c|}
\hline Sampled: & & & Weight & \multicolumn{2}{|c|}{ Non-Quartz } & Quartz \\
\cline { 1 - 4 } Test Run: & & Size Mesh & $\mathrm{g}$ & Vol \% & $\mathrm{g}$ & $\mathrm{g}$ \\
\hline Source: & & +30 & - & - & - & - \\
\hline Location: & & +50 & 0.6 & $95 \%$ & 0.57 & 0.03 \\
\hline Sample Type: & & +100 & 4.7 & $10 \%$ & 0.47 & 4.23 \\
\hline Sample Wt., g: & 207.5 & +200 & 41.1 & $1 \%$ & 0.41 & 40.69 \\
\hline $\begin{array}{l}\text { Insoluble Residue Wt., } \\
\text { g: }\end{array}$ & 49.5 & -200 & 2.9 & N/A & +200 Qtz.g: & 44.95 \\
\hline Sieving Loss/Gain, \%: & 0.4 & Total: & 49.3 & & $+\mathbf{2 0 0}$ Qtz.,\%: & 22 \\
\hline
\end{tabular}


Table 39: IR Data for Material Passing WVDOH Method No Skid Sample \#1

\begin{tabular}{|l|r|c|c|c|c|c|}
\hline Sampled: & & & Weight & \multicolumn{2}{|c|}{ Non-Quartz } & Quartz \\
\cline { 1 - 4 } \cline { 5 - 7 } Test Run: & & Size Mesh & $\mathrm{g}$ & Vol \% & $\mathrm{g}$ & $\mathrm{g}$ \\
\hline Source: & & +30 & - & - & - & - \\
\hline Location: & & +50 & 1.1 & $97 \%$ & 1.07 & 0.03 \\
\hline Sample Type: & & +100 & 4.3 & $60 \%$ & 2.58 & 1.72 \\
\hline Sample Wt., g: & 208.6 & +200 & 14.8 & $30 \%$ & 4.44 & 10.36 \\
\hline $\begin{array}{l}\text { Insoluble Residue Wt., } \\
\text { g: }\end{array}$ & 32.8 & -200 & 12.5 & N/A & +200 Qtz.g: & 12.11 \\
\hline Sieving Loss/Gain, \%: & 0.3 & Total: & 32.7 & & $+\mathbf{2 0 0}$ Qtz.,\%: & 6 \\
\hline
\end{tabular}

Table 40: IR Data for Material Passing WVDOH Method No Skid Sample \#2

\begin{tabular}{|l|r|c|c|c|c|c|}
\hline Sampled: & & & Weight & \multicolumn{2}{|c|}{ Non-Quartz } & Quartz \\
\cline { 1 - 4 } \cline { 5 - 7 } Test Run: & & Size Mesh & $\mathrm{g}$ & Vol \% & $\mathrm{g}$ & $\mathrm{g}$ \\
\hline Source: & & +30 & - & - & - & - \\
\hline Location: & & +50 & 1.5 & $99 \%$ & 1.49 & 0.02 \\
\hline Sample Type: & & +100 & 4.9 & $70 \%$ & 3.43 & 1.47 \\
\hline Sample Wt., g: & 205.1 & +200 & 15.1 & $40 \%$ & 6.04 & 9.06 \\
\hline $\begin{array}{l}\text { Insoluble Residue Wt., } \\
\text { g: }\end{array}$ & 33.9 & -200 & 12.2 & N/A & +200 Qtz.,g: & 10.55 \\
\hline Sieving Loss/Gain, \%: & 0.6 & Total: & 33.7 & & $\mathbf{+ 2 0 0}$ Qtz.,\%: & 5 \\
\hline
\end{tabular}




\section{Insoluble Residue per Total Blend of Sample}

Table 41: IR Data for Total Blend All Skid Sample \#1

\begin{tabular}{|c|c|c|c|c|c|c|}
\hline Sampled: & & \multirow[b]{2}{*}{$\begin{array}{l}\text { Size } \\
\text { Mesh }\end{array}$} & Weight & \multicolumn{2}{|c|}{ Non-Quartz } & Quartz \\
\hline Test Run: & & & $\mathrm{g}$ & $\begin{array}{c}\text { Vol } \\
\% \\
\end{array}$ & $\mathrm{~g}$ & $\mathrm{~g}$ \\
\hline Source: & & +30 & 1.1 & $100 \%$ & 1.09 & 0.01 \\
\hline Location: & & +50 & 1.1 & $97 \%$ & 1.07 & 0.03 \\
\hline Sample Type: & & +100 & 3.5 & $5 \%$ & 0.18 & 3.33 \\
\hline Sample Wt., g: & 205.2 & +200 & 27.6 & $1 \%$ & 0.28 & 27.32 \\
\hline Insoluble Residue Wt., g: & 36.5 & -200 & 3.3 & $\mathrm{~N} / \mathrm{A}$ & +200 Qtz.,g: & 30.69 \\
\hline Sieving Loss/Gain, \%: & -0.3 & Total: & 36.6 & & +200 Qtz.,\%: & 15 \\
\hline
\end{tabular}

Table 42: IR Data for Total Blend All Skid Sample \#2

\begin{tabular}{|c|c|c|c|c|c|c|}
\hline Sampled: & & \multirow[b]{2}{*}{$\begin{array}{c}\text { Size } \\
\text { Mesh }\end{array}$} & Weight & \multicolumn{2}{|c|}{ Non-Quartz } & Quartz \\
\hline Test Run: & & & $\mathrm{g}$ & $\begin{array}{c}\text { Vol } \\
\% \\
\end{array}$ & $\mathrm{~g}$ & $\mathrm{~g}$ \\
\hline Source: & & +30 & 0.2 & $100 \%$ & 0.20 & 0.00 \\
\hline Location: & & +50 & 0.7 & $97 \%$ & 0.68 & 0.02 \\
\hline Sample Type: & & +100 & 4.6 & $3 \%$ & 0.14 & 4.46 \\
\hline Sample Wt., g: & 220.4 & +200 & 42 & $1 \%$ & 0.42 & 41.58 \\
\hline Insoluble Residue Wt., g: & 52.4 & -200 & 4.7 & N/A & +200 Qtz.,g: & 46.06 \\
\hline Sieving Loss/Gain, \%: & 0.4 & Total: & 52.2 & & +200 Qtz.,\%: & 21 \\
\hline
\end{tabular}

Table 43: IR Data for Total Blend Opposite Skid Sample \#1

\begin{tabular}{|c|c|c|c|c|c|c|}
\hline Sampled: & & \multirow[b]{2}{*}{$\begin{array}{l}\text { Size } \\
\text { Mesh }\end{array}$} & Weight & \multicolumn{2}{|c|}{ Non-Quartz } & Quartz \\
\hline Test Run: & & & $\mathrm{g}$ & $\begin{array}{c}\text { Vol } \\
\%\end{array}$ & $\mathrm{~g}$ & $\mathrm{~g}$ \\
\hline Source: & & +30 & 0.3 & $99 \%$ & 0.30 & 0.00 \\
\hline Location: & & +50 & 1.2 & $97 \%$ & 1.16 & 0.04 \\
\hline Sample Type: & & +100 & 3.5 & $40 \%$ & 1.40 & 2.10 \\
\hline Sample Wt., g: & 202.5 & +200 & 24.1 & $10 \%$ & 2.41 & 21.69 \\
\hline Insoluble Residue Wt., g: & 38.5 & -200 & 9.3 & N/A & +200 Qtz.,g: & 23.83 \\
\hline Sieving Loss/Gain, \%: & 0.3 & Total: & 38.4 & & +200 Qtz.,\%: & 12 \\
\hline
\end{tabular}


Table 44: IR Data for Total Blend Opposite Skid Sample \#2

\begin{tabular}{|c|c|c|c|c|c|c|}
\hline Sampled: & & \multirow[b]{2}{*}{$\begin{array}{l}\text { Size } \\
\text { Mesh }\end{array}$} & Weight & \multicolumn{2}{|c|}{ Non-Quartz } & Quartz \\
\hline Test Run: & & & $\mathrm{g}$ & $\begin{array}{c}\text { Vol } \\
\%\end{array}$ & $\mathrm{~g}$ & $\mathrm{~g}$ \\
\hline Source: & & +30 & 0.6 & $99 \%$ & 0.59 & 0.01 \\
\hline Location: & & +50 & 1.8 & $97 \%$ & 1.75 & 0.05 \\
\hline Sample Type: & & +100 & 3.8 & $40 \%$ & 1.52 & 2.28 \\
\hline Sample Wt., g: & 202 & +200 & 20.4 & $10 \%$ & 2.04 & 18.36 \\
\hline Insoluble Residue Wt., g: & 37.1 & -200 & 10.4 & N/A & +200 Qtz.,g: & 20.70 \\
\hline Sieving Loss/Gain, \%: & 0.3 & Total: & 37 & & +200 Qtz.,\%: & 10 \\
\hline
\end{tabular}

Table 45: IR Data for Total Blend Per Design Sample \#1

\begin{tabular}{|c|c|c|c|c|c|c|}
\hline Sampled: & & \multirow[b]{2}{*}{$\begin{array}{l}\text { Size } \\
\text { Mesh }\end{array}$} & Weight & \multicolumn{2}{|c|}{ Non-Quartz } & Quartz \\
\hline Test Run: & & & $\mathrm{g}$ & $\begin{array}{c}\text { Vol } \\
\%\end{array}$ & $\mathrm{~g}$ & $\mathrm{~g}$ \\
\hline Source: & & +30 & 0.2 & $99 \%$ & 0.20 & 0.00 \\
\hline Location: & & +50 & 1 & $95 \%$ & 0.95 & 0.05 \\
\hline Sample Type: & & +100 & 4.1 & $15 \%$ & 0.62 & 3.49 \\
\hline Sample Wt., g: & 209.7 & +200 & 26.6 & $5 \%$ & 1.33 & 25.27 \\
\hline Insoluble Residue Wt., g: & 41.3 & -200 & 9.2 & N/A & +200 Qtz.,g: & 28.81 \\
\hline Sieving Loss/Gain, \%: & 0.5 & Total: & 41.1 & & +200 Qtz.,\%: & 14 \\
\hline
\end{tabular}

Table 46: IR Data for Total Blend Per Design Sample \#2

\begin{tabular}{|l|r|c|c|c|c|c|}
\hline Sampled: & & \multirow{2}{*}{\begin{tabular}{c} 
Size \\
\cline { 5 - 7 } Test Run:
\end{tabular}} & Weight & \multicolumn{2}{|c|}{ Non-Quartz } & Quartz \\
\cline { 5 - 7 } & & Mesh & $\mathrm{g}$ & $\begin{array}{c}\text { Vol } \\
\%\end{array}$ & $\mathrm{~g}$ & $\mathrm{~g}$ \\
\hline Source: & & +30 & 0.4 & $99 \%$ & 0.40 & 0.00 \\
\hline Location: & & +50 & 1.5 & $97 \%$ & 1.46 & 0.04 \\
\hline Sample Type: & & +100 & 3.6 & $15 \%$ & 0.54 & 3.06 \\
\hline Sample Wt., g: & 203.5 & +200 & 23.1 & $5 \%$ & 1.16 & 21.95 \\
\hline Insoluble Residue Wt., g: & 38.8 & -200 & 9.8 & N/A & +200 Qtz.,g: & 25.05 \\
\hline Sieving Loss/Gain, \%: & 1.0 & Total: & 38.4 & & +200 Qtz.\%\%: & 12 \\
\hline
\end{tabular}


Table 47: IR Data for Total Blend No Skid Sample \#1

\begin{tabular}{|c|c|c|c|c|c|c|}
\hline Sampled: & & \multirow[b]{2}{*}{$\begin{array}{l}\text { Size } \\
\text { Mesh }\end{array}$} & Weight & \multicolumn{2}{|c|}{ Non-Quartz } & Quartz \\
\hline Test Run: & & & $\mathrm{g}$ & $\begin{array}{c}\text { Vol } \\
\%\end{array}$ & $\mathrm{~g}$ & $\mathrm{~g}$ \\
\hline Source: & & +30 & 3.7 & $99 \%$ & 3.66 & 0.04 \\
\hline Location: & & +50 & 5.4 & $99 \%$ & 5.35 & 0.05 \\
\hline Sample Type: & & +100 & 3.4 & $70 \%$ & 2.38 & 1.02 \\
\hline Sample Wt., g: & 204 & +200 & 12.3 & $40 \%$ & 4.92 & 7.38 \\
\hline Insoluble Residue Wt., g: & 38.5 & -200 & 13 & N/A & +200 Qtz.,g: & 8.49 \\
\hline Sieving Loss/Gain, \%: & 1.8 & Total: & 37.8 & & +200 Qtz.,\%: & 4 \\
\hline
\end{tabular}

Table 48: IR Data for Total Blend No Skid Sample \#2

\begin{tabular}{|c|c|c|c|c|c|c|}
\hline Sampled: & & \multirow[b]{2}{*}{$\begin{array}{l}\text { Size } \\
\text { Mesh }\end{array}$} & Weight & \multicolumn{2}{|c|}{ Non-Quartz } & \multirow{2}{*}{$\begin{array}{c}\text { Quartz } \\
\mathrm{g}\end{array}$} \\
\hline Test Run: & & & $\mathrm{g}$ & $\begin{array}{c}\text { Vol } \\
\%\end{array}$ & $\mathrm{~g}$ & \\
\hline Source: & & +30 & 3.6 & $100 \%$ & 3.58 & 0.02 \\
\hline Location: & & +50 & 4.5 & $99 \%$ & 4.46 & 0.04 \\
\hline Sample Type: & & +100 & 3.8 & $60 \%$ & 2.28 & 1.52 \\
\hline Sample Wt., g: & 201.5 & +200 & 17.7 & $20 \%$ & 3.54 & 14.16 \\
\hline Insoluble Residue Wt., g: & 40.8 & -200 & 10.9 & N/A & +200 Qtz.,g: & 15.74 \\
\hline Sieving Loss/Gain, \%: & 0.7 & Total: & 40.5 & & +200 Qtz.,\%: & 8 \\
\hline
\end{tabular}

